\title{
Methane Recovery from Animal Manures: A Current Opportunities Casebook
}

P. Lusk

Resource Development Associates

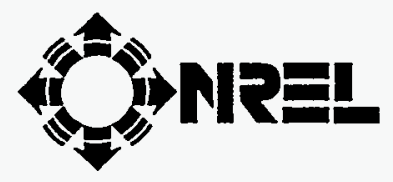

National Renewable Energy Laboratory 1617 Cole Boulevard Golden, Colorado 80401-3393

A national laboratory of the U.S. Department of Energy Managed by Midwest Research Institute for the U.S. Department of Energy

Under Contract No. DE-AC36-83CH10093

Prepared under Subcontract Number CAE-3-13383-01

December 1994
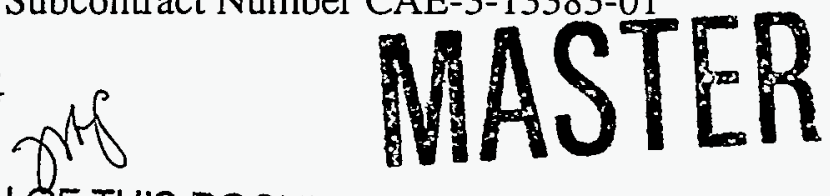
This publication was reproduced from the best available camera-seady copy submitted by the subcontractor and received no editorial review at NREL.

\section{NOTICE}

This report was prepared as an account of work sponsored by an agency of the United States government. Neither the United States government nor any agency thereof, nor any of their employees, makes any warranty, express or implied, or assumes any legal liability or responsibility for the accuracy, completeness, or usefulness of any information, apparatus, product, or process disclosed, or represents that its use would not infringe privately owned rights. Reference herein to any specific commercial product, process, or service by trade name, trademark, manufacturer, or otherwise does not necessarily constitute or imply its endorsement, recommendation, or favoring by the United States government or any agency thereof. The views and opinions of authors expressed herein do not necessarily state or reflect those of the United States government or any agency thereof.

Available to DOE and DOE contractors from:

Office of Scientific and Technical Information (OSTI)

P.O. Box 62

Oak Ridge, TN 37831

Prices available by calling (615) $576-8401$

Available to the public from:

National Technical Information Service (NTIS)

U.S. Department of Commerce

5285 Port Royal Road

Springfield, VA 22161

(703) $487-4650$ 


\section{DISCLAIMER}

Portions of this document may be illegible in electronic image products. Images are produced from the best available original document. 


\section{TABLE OF CONTENTS}

PAGE

ABSTRACT 1

Section 1.0

EXECUTIVE SUMMARY

Section 2.0

INTRODUCTION TO ANAEROBIC DIGESTION 6

3.2 Dairy Farms with Electricity Generation and Low Manure Collected .....17

3.2.1 250-Head Digesters with Electricity Generation

3.2.2 500-Head Digesters with Electricity Generation

3.2.3 1000-Head Digesters with Electricity Generation

3.2.4 Regression Analyses of Dairy Farms with Electricity Generation and Low Manure Collected

3.3 Dairy Farms with Electricity Generation and High Manure Collected .....19

250-Head Digesters with Electricity Generation ............................20

3.3.2 500-Head Digesters with Electricity Generation ...........................20

3.3.3 1000-Head Digesters with Electricity Generation ..........................20

3.3.4 Regression Analyses of Dairy Farms with Electricity Generation and High Manure Collected

3.4 Swine Farms with Electricity Generation and All Manure Collected ......23

3.4.1 500-Head Digesters with Electricity Generation ...........................23

3.4.2 1000-Head Digesters with Electricity Generation ..........................23 
3.4.3 5000-Head Digesters with Electricity Generation

3.4.4 Regression Analyses of Swine Farms with Electricity Generation and All Manure Collected ................................................. 24

3.5 Co-Product Utilization Illustration .25

3.5.1 1000-Head California Dairy with Covered Lagoon Digester .25

3.5.2 300-Head South Dakota Dairy with Plug Flow Digester 26

\section{5 .3} 10000-Head Nebraska Swine Farm with Complete Mix Digester .26 
TABLE OF CONTENTS CONTINUED

PAGE

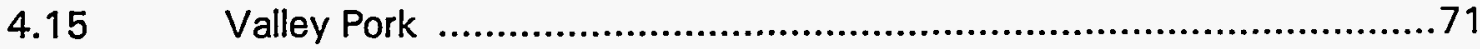

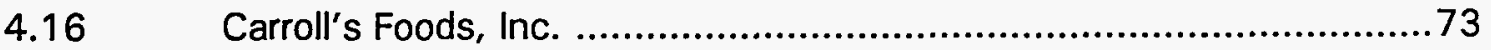

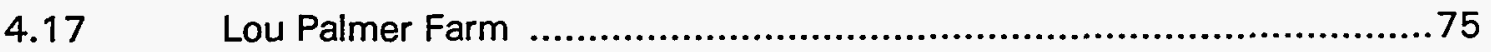

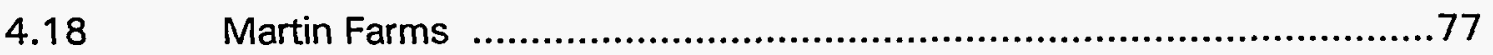

4.19 Methane Energy \& Agricultural Development (MEAD) ......................79

Summary of Case Studies $\quad$ S....................................................

Section 5.0

SUMMARY CONCLUSIONS .84

Section 6.0

SYSTEM DESIGNER/INSTALLER CONTACTS

Section 7.0

OTHER CONTACTS .88 


\section{LIST OF TABLES}

PAGE

Table 1.2.1

Table 3.1.1

Table 3.1 .2

Table 3.2.1

Table 3.2.2

Table 3.2.3

Table 3.2 .4

Table 3.2.5

Table 3.3.1

Table 3.3.2

Table 3.3.3

Table 3.3.4

Table 3.3.5

Table 3.3.6
Status of Farm-Based Digesters in the United States 2

Anaerobic Digestion of Livestock Manures Datatable 13

Macro Variables Used in CashFlow Model 15 250-Head Dairy Farm with Electricity Generation and Low Manure Collected

500-Head Dairy Farm with Electricity Generation and Low Manure Collected

1000-Head Dairy Farm with Electricity Generation and Low Manure Collected

Summary of Estimated Regression Analysis Values for Dairy Farm Covered Lagoon Digester with Electricity Generation and Low Manure Collected

Summary of Estimated Regression Analysis Values for Dairy Farm Complete Mix Digester with Electricity Generation and Low Manure Collected

250-Head Dairy Farm with Electricity Generation and High Manure Collected

500-Head Dairy Farm with Electricity Generation and High Manure Collected

1000-Head Dairy Farm with Electricity Generation and High Manure Collected

Summary of Estimated Regression Analysis Values for Dairy Farm Covered Lagoon Digester with Electricity Generation and High Manure Collected

Summary of Estimated Regression Analysis Values for Dairy Farm Complete Mix Digester with Electricity Generation and High Manure Collected

Summary of Estimated Regression Analysis Values for Dairy Farm Plug Flow Digester with Electricity Generation and High Manure

Collected 
LIST OF TABLES CONTINUED

PAGE

Table 3.4.1

Table 3.4.2

Table 3.4.3

Table 3.4 .4

Table 3.4.5

Table 3.5.1

Table 3.5.2

Table 3.5.3
500-Head Swine Farm with Electricity Generation and All Manure

Collected 23 1000-Head Dairy Farm with Electricity Generation and All Manure Collected 23 5000-Head Dairy Farm with Electricity Generation and High Manure Collected 24

Summary of Estimated Regression Analysis Values for Swine Farm Covered Lagoon Digester with Electricity Generation and All Manure Collected 24

Summary of Estimated Regression Analysis Values for 'Swine Farm Complete Mix Digester with Electricity Generation and All Manure Collected 25 1000-Head California Dairy Farm with Covered Lagoon Digester ... 26 300-Head South Dakota Dairy Farm with Plug Flow Digester ....... 26 10000-Head Nebraska Swine Farm with Complete Mix Digester ... 27 


\section{LIST OF FIGURES}

\section{PAGE}

Figure 3.2.1

Figure 3.2.2

Figure 3.2.3

Figure 3.2.4

Figure 3.2.5

Figure 3.2.6

Figure 3.2.7

Figure 3.2.8

Figure 3.2.9

Figure 3.2.10

Figure 3.2.11

Figure 3.2.12

Figure 3.2.13

Figure 3.3.1

Figure 3.3.2
Comparative Cumulative Cash Flow for 250-Head Dairy Farm Digesters with Low Manure Collected .................................28

Comparative Sensitivity of Net Present Value to Real Discount Rate for 250-Head Dairy Farm Digesters with Low Manure Collected .....28

Comparative Sensitivity of Internal Rate of Return to Project Life for 250-Head Dairy Farm Digesters with Low Manure Collected .........28

Comparative Cumulative Cash Flow for 250-Head Dairy Farm Digesters with High Manure Collected ....................................29

Comparative Sensitivity of Net Present Value to Real Discount Rate for 500-Head Dairy Farm Digesters with Low Manure Collected ....29

Comparative Sensitivity of Internal Rate of Return to Project Life for 500-Head Dairy Farm Digesters with Low Manure Collected ..........29

Comparative Cumulative Cash Flow for 1000-Head Dairy Farm Digesters with Low Manure Collected 30 Comparative Sensitivity of Net Present Value to Real Discount Rate for 1000-Head Dairy Farm Digesters with Low Manure Collected ...30

Comparative Sensitivity of Internal Rate of Return to Project Life for 1000-Head Dairy Farm Digesters with Low Manure Collected ........30

Cost Projection of Dairy Covered Lagoon Digester with Electricity Generation and Low Manure Collected ............................... 31

Internal Rate of Return Projection of Dairy Covered Lagoon Digester with Electricity Generation and Low Manure Collected ..................31

Cost Projection of Dairy Complete Mix Digester with Electricity Generation and Low Manure Collected ................................ 31

Internal Rate of Return Projection of Dairy Complete Mix Digester with Electricity Generation and Low Manure Collected 32

Comparative Cumulative Cash Flow for 250-Head Dairy Farm

Digesters with High Manure Collected ................................. 32

Comparative Sensitivity of Net Present Value to Real Discount Rate for 250-Head Dairy Farm Digesters with High Manure Collected ....32 
LIST OF FIGURES CONTINUED

PAGE

Figure 3.3.3

Figure 3.3.4

Figure 3.3.5

Figure 3.3.6

Figure 3.3.7

Figure 3.3.8

Figure 3.3.9

Figure 3.3.10

Figure 3.3.11

Figure 3.3.12

Figure 3.3 .13

Figure 3.3.14

Figure 3.3.15

Figure 3.4.1

Figure 3.4 .2
Comparative Sensitivity of Internal Rate of Return to Project Life for 250-Head Dairy Farm Digesters with High Manure Collected 33

Comparative Cumulative Cash Flow for 250-Head Dairy Farm

Digesters with High Manure Collected 33

Comparative Sensitivity of Net Present Value to Real Discount Rate for 500-Head Dairy Farm Digesters with High Manure Collected .... 33

Comparative Sensitivity of Internal Rate of Return to Project Life for 500-Head Dairy Farm Digesters with High Manure Collected 34

Comparative Cumulative Cash Flow for 1000-Head Dairy Farm Digesters with High Manure Collected 34

Comparative Sensitivity of Net Present Value to Real Discount Rate for 1000-Head Dairy Farm Digesters with High Manure Collected .. 34

Comparative Sensitivity of Internal Rate of Return to Project Life for 1000-Head Dairy Farm Digesters with High Manure Collected ....... 35

Cost Projection of Dairy Covered Lagoon Digester with Electricity Generation and High Manure Collected 35

Internal Rate of Return Projection of Dairy Covered Lagoon Digester with Electricity Generation and High Manure Collected 35

Cost Projection of Dairy Complete Mix Digester with Electricity Generation and High Manure Collected ................................. 36

Internal Rate of Return Projection of Dairy Complete Mix Digester with Electricity Generation and High Manure Collected 36

Cost Projection of Dairy Plug Flow Digester with Electricity Generation and High Manure Collected 36 Internal Rate of Return Projection of Dairy Plug Flow Digester with Electricity Generation and High Manure Collected 37

Comparative Cumulative Cash Flow for 500-Head Swine Farm Digesters with All Manure Collected 37

Comparative Sensitivity of Net Present Value to Real Discount Rate for 500-Head Swine Farm Digesters with All Manure Collected ..... 37 
Figure 3.4 .3

Figure 3.4.4

Figure 3.4.5

Figure 3.4.6

Figure 3.4.7

Figure 3.4.8

Figure 3.4.9

Figure 3.4.10

Figure 3.4.11

Figure 3.4.12

Figure 3.4 .13

Figure 4.1

Figure 4.2
Comparative Sensitivity of Internal Rate of Return to Project Life for 500-Head Swine Farm Digesters with All Manure Collected 38

Comparative Cumulative Cash Flow for 1000-Head Swine Farm Digesters with All Manure Collected 38

Comparative Sensitivity of Net Present Value to Real Discount Rate for 1000-Head Swine Farm Digesters with All Manure Collected ....38

Comparative Sensitivity of Internal Rate of Return to Project Life for 1000-Head Swine Farm Digesters with All Manure Collected 39

Comparative Cumulative Cash Flow for 5000-Head Swine Farm Digesters with All Manure Collected 39

Comparative Sensitivity of Net Present Value to Real Discount Rate for 5000-Head Swine Farm Digesters with All Manure Collected ....39

Comparative Sensitivity of Internal Rate of Return to Project Life for 5000-Head Swine Farm Digesters with All Manure Collected .... 40

Cost Projection of Swine Covered Lagoon Digester with Electricity Generation and All Manure Collected .40

Internal Rate of Return Projection of Swine Covered Lagoon Digester with Electricity Generation and All Manure Collected .......40

Cost Projection of Swine Complete Mix Digester with Electricity Generation and All Manure Collected

Internal Rate of Return Projection of Swine Complete Mix Digester with Electricity Generation and All Manure Collected 41

Status of Farm-Based Anaerobic Digesters in the US .83

Performance of Farm-Based Anaerobic Digesters in the US .83 


\section{ABSTRACT}

Growth and concentration of the livestock industry creates opportunities for the proper disposal of the large quantities of manures generated at dairy, swine and poultry farms. Pollutants from unmanaged livestock wastes can degrade the environment, and methane emitted from decomposing manure may contribute to global climate change.

One manure management system provides not only pollution prevention but also converts a manure management problem into a new profit center. Economic evaluations and case studies of operating systems indicate that the anaerobic digestion of livestock manures is a commercially-available bioconversion technology with considerable potential for providing profitable co-products including a cost-effective renewable fuel for livestock production operations.

This Casebook examines some of the current opportunities for the recovery of methane from the anaerobic digestion of animal manures. US livestock operations currently employ four types of anaerobic digester technology: slurry, plug flow, complete mix, and covered lagoon. An introduction to the engineering economies of these technologies is provided, and possible end-use applications for the methane gas generated by the digestion process are discussed. The economic evaluations are based on engineering studies of digesters that generate electricity from the recovered methane. Regression models, which can be used to estimate digester cost and internal rate of return, are developed from the evaluations.

Case studies of operating digesters, including project and maintenance histories, and the operator's "lessons learned", are included as a reality check. Factors necessary for successful projects, as well as a list of reasons explaining why some anaerobic digestion projects fail, are provided. The role of farm management is key; not only must digesters be well engineered and built with high-quality components, they must also be sited at farms willing to incorporate the uncertainties of a new technology.

Site-specific analysis must guide the decision to implement any biologically-based technology. Although few generalizations can be made, the Casebook offers the following observations. The slurry digester design may offer great benefits beyond its low cost to install and simplified operation. When combined with a mechanical scraping system for manure collection, there is little added water compared to hydraulic flushing; therefore, the methane and odor associated with manure decomposition can be minimized to the greatest extent possible. Covered lagoon digesters appear to have great economic merit for those operations in the Southeast and West that currently incorporate hydraulic flushing for manure collection and conventional lagoons for waste management. Plug flow digestion is economically sensitive to co-product utilization and other off-sets from current manure management practices, but it is less expensive and technically easier to operate and maintain than a comparable complete mix digester. Complete mix digesters have higher capital costs and operating requirements which generally limit application to very large facilities having waste streams with total solid concentrations too low for plug flow digestion and to locations where the climate is too cold to economically justify covering a lagoon.

Well over two decades of research has provided much information about how manure can be converted to an energy source; however, the American farmer has not been motivated to adopt new practices. More cost-effective and easily-managed manure management techniques are still needed to encourage farmers to use animal manure for conversion into energy and nutrients, especially for smaller farms.

Anaerobic digestion benefits farmers monetarily and mitigates possible manure pollution problems, thereby sustaining development while maintaining environmental quality. Moreover, rural economic development will benefit from the implicit multiplier effect resulting from jobs created by implementing digester systems. Promising future waste-toprofit activities may add to the economic performance of anaerobic digestion. New enduse applications which provide added value to co-products are discussed. Finally, anaerobic digestion has considerable potential beyond agribusiness. Examples of digesters currently employed by other industries are provided.

KEYWORDS: anaerobic digestion, bioconversion, engineering economy, environmental quality, pollution prevention, sustainable development. 


\subsection{Executive Summary}

Growth and concentration of the livestock industry in the US creates new opportunities for the proper disposal of manures generated at dairy, swine and poultry farms. The principal pollutants from decomposing livestock manures are methane emissions, ammonia, excess nutrients and pathogens, along with biochemical oxygen demand (BOD). The major pollution problems associated with these wastes are surface and ground water contamination, and surface air pollution due to odors, dust, volatile organic acids, and ammonia. There is also concern about the contribution of methane emissions to global climate change. Consequently, manure management systems that enable pollution prevention as well as energy production are becoming increasingly attractive.

\subsection{Status of Livestock Manure Anaerobic Digestion in the US}

This Casebook examines some of the conversion technologies employed to manufacture methane-rich biogas from the anaerobic digestion of animal manures. US livestock operations currently use four types of anaerobic digester technology: slurry, plug flow, complete mix, and covered lagoons. The Casebook provides an introduction to digester technology and discusses possible end-use applications for the biogas product. Following the overview is a series of pro forma economic evaluations. The economic evaluations are based on engineering studies of digesters that generate electricity from recovered biogas on dairy and swine farms with differing herd sizes.

Regression models, which can be used to estimate digester cost and internal rate of return as a function of herd size, are developed from the evaluations. Case studies of operating digesters, including information on actual project and maintenance histories, and on the operator's "lessons learned", are provided. The economic evaluations and case studies indicate that anaerobic digestion of livestock manures is a commercially-available bioconversion technology with potential for providing profitable co-products including a renewable fuel for livestock production operations.

\section{2 "Lessons Learned"}

To provide a reality base to the economic evaluations mentioned above, the Casebook surveys a number of operating and non-operating anaerobic digestion systems and compiles information on actual project and maintenance histories. Operator's "lessons learned" offer insight into practical experience with digesters.

Table 1.2.1 provides a numerical status report of farm-based anaerobic digesters in the US ${ }^{1}$. The data presented includes the digesters that are installed on or were planned for working dairy, swine, and caged-layer poultry farms. It excludes 65-70 digesters that are installed on or were planned for beef farms, and those digesters that are primarily. university research-oriented.

TABLE 1.21: Status of Farm-Based Digesters in the United States

\begin{tabular}{|c|c|c|c|c|c|}
\hline & Sumy & Plug: & MiX & Lagoon & TOFAL \\
\hline Operating & 5 & $\dddot{g}$ & 4 & 7 & 25 \\
\hline Not & $\theta$ & 30 & 较. & 3 & 46 \\
\hline Operating & & & & & \\
\hline Never & $\ddot{0}$ & 8 & 1 & 1 & 10 \\
\hline Built & & & & & \\
\hline TOTAL & 5 & 47 & : & 11 & 81 \\
\hline
\end{tabular}

The numerical status is not the whole story. Surveyed farmers who have installed and continue to operate an anaerobic digester are generally satisfied with their investment decision. Some chose to install a digester for non-economic reasons, primarily to control odor or contain excess nutrient run-off. Those farmers have found that the returns provided from electricity and other co-product sales from the digester, however limited, are preferred to the sunk-cost of conventional disposal which provides zero return on investment. Moreover, without the environmental benefits provided by anaerobic technology, some might have been forced out of livestock production. Anaerobic digestion is sometimes the only technology that

1 ICF Consulting Associates (1992) US Anaerobic Farm Digester Study. Unpublished report prepared for the US Environmental Protection Agency. Modified by Resource Development Associates, 1994. 
allows growth in the livestock production business. Turning a waste liability into a profit center that generates annual revenues can moderate the impacts of declining commodity prices and can diversify farm income.

None of the farmers surveyed to date with an operating anaerobic digester said that they regret their basic decision. Most would have preferred to spend less money on its design and installation, but they are unsure of exactly how costs could have been cut. Many seek new ways to increase profitability by the sales of co-products, primarily the digested solids. They would like additional assistance in determining how best to optimize the added-value of co-products. Beating the odds, a few have met the challenge of making their systems work despite bad design or equipment. The hard knock of practical experience makes them the true superstars of farm-based anaerobic digestion technology in the US.

Still, at face-value, the performance data is not encouraging to a farmer considering whether to install an anaerobic digester as a waste treatment option. Overall, the chance for failure, i.e., owning a non-operating anaerobic digester, is 65 percent in the US. This is roughly two times greater than the possibility of successfully employing a working digester. Excluding those that were never built, among the individual types of farm-based digesters, the failure rate for complete mix and plug flow technologies is a staggering 75 percent. For covered lagoon digesters, the failure rate is $\mathbf{3 0}$ percent. Because there are far fewer operating slurry digesters, their current 100 percent success rate is certainly inconclusive. Once slurry digesters have a larger market share, the opportunity for system failures due to poor design, fabrication, and operation will equal the other technologies, and the slurry's performance can then be gauged.

The reasons for digester failure go beyond bad design or equipment; many digesters in the US were shut down because of farms being sold or declining energy prices. One encouraging note is that the reliability of the digesters constructed since 1982 is far better than those digesters constructed during the period 1972-
1982. This is generally due to a more simplified digester design.

\subsection{Cautious Optimism}

The economic evaluations and case studies indicate that anaerobic digestion of livestock manures is a commercially available technology with potential for providing a cost-effective renewable fuel which can readily be used by a number of livestock production operations.

Of the conversion systems evaluated to-date, slurry-based designs may offer the most benefits beyond their low cost to install and simplified operation. When combined with a mechanical scraping system for manure collection, there is little added water compared to hydraulic flushing. Because the organic acids are not volitilized, the methane and odor associated with manure decomposition can be minimized to the greatest extent possible. Covered lagoon digesters appear to have great economic merit for the large number of swine and dairy operations in the Southeast and West which incorporate hydraulic flushing for manure collection and conventional anaerobic lagoons for waste treatment. Plug flow digestion is economically sensitive to co-product utilization and other off-sets from current manure management practices, but it is less expensive and technically easier to operate and maintain than a comparable complete mix digester. Complete mix digesters have higher capital costs and operating and maintenance requirements than covered lagoon and plug flow digesters. This will generally limit complete mix digester applications to very large farms or centralized facilities, or to farms having waste streams with total solid concentrations too low for plug flow digestion and to locations where the climate is too cold to economically justify covering a lagoon.

It must be remembered that the anaerobic digestion process is biologically based and therefore must be evaluated and implemented on a site-specific basis. As a result, few meaningful generalizations can be made. Factors for successful project implementation include: an adequate match of digester type to the farm's manure management program, competent design and installation which simplifies digester operation and maintenance, 
and maximizing co-product utilization to enhance economic performance. New designs like the slurry digester used with scrape systems or the covered lagoon digester used with flush systems offer a more simplified, less costly, approach.

The list of reasons explaining why some anaerobic digestion projects fail must be headed by bad design or installation. When selecting the "best" qualified contractor to design or install an anaerobic digester system, an investor should rarely consider a firm without a significant amount of practical experience in the field. Poor equipment and materials selection is the second most common reason why digesters fail. Although buying the best and most expensive equipment and materials available cannot guarantee project success, amortizing the cost of quality components over the life-cycle of the project is a far better prospect than experiencing a failure resulting from the use of inferior products.

The role of farm management is key; not only must digesters be well engineered and built with high-quality components, they must also be sited at accommodating farms willing to incorporate the uncertainties of a new technology.

\subsection{And What of the Future?}

The conversion of agricultural wastes, animal manures in particular, into a renewable energy resource has been the focus of intensive research for well over two decades. Much has been learned about how manure can be utilized as an energy and nutrient source. Several available digester systems are both costeffective and easily managed; however, the American farmer has not been motivated to adopt these new practices. More cost-effective and easily-managed manure management techniques are still needed, especially for smaller farms, to encourage the farmer's use of animal waste for energy and nutrients.

Not only will farmers benefit monetarily, the use of anaerobic digestion also will help mitigate animal manure's contribution to air, surface, and ground water pollution. There are additional indirect benefits for rural economic development from the implicit multiplier effect resulting from direct jobs that can be created by providing, installing and maintaining the digester system equipment. The implicit multiplier effect of integrated agricultural production and processing can be two to three times traditional production-only values.

Promising future waste-to-profit activities may enhance the economic performance of the overall farm manure management system. New end-use applications that can provide added value to co-products and maximize nutrient utilization include fuel cells for the generation of electricity and process heat, greenhouses, and algae, plant and fish aquaculture. The use of attached greenhouses can also provide enhanced plant growth rates if the available carbon dioxide is captured. Discharged waste water effluent can also be discharged into ponds and used as a growth culture for highprotein content algae or other aquatic plants.

A combination of these activities could be incorporated on farms with multi-function production systems. "Agri-Plex" would be a more accurate name for such an operation. One project in Texas ${ }^{2}$ is combining an anaerobic digester and the use of effluents to support the growth of algae, duckweed, and fish. After initial anaerobic treatment, the effluent will flow to additional ponds supporting the growth of algae and duckweed. Some algae and duckweed will be harvested and processed into animal feeds. The remainder will be used for the culture of fish, including tilapia, that will be processed into fish meal or sold as bait fish. An additional product will be a strain of bacteria that converts hydrogen sulfides into elemental sulfur, thereby helping reduce the odors associated with manure decomposition. Another potential revenue stream under consideration is the production of water lilies, Louisiana irises, and other ornamental aquatic plants. While this system is capital and labor

2

Parker and Felder (1994) "Bioenergy Production: Integrating Livestock Treatment with Byproduct Development", Proceedings, Bioenergy '94 Conference. S.L. Sargent, ed., Western Regional Biomass Energy. Program, Golden, CO, Vol. 1, pp. 211-218. 
intensive, it provides the greatest potential for economic return.

Extending the anaerobic digestion process to recover methane has considerable potential beyond the farm to other industries with a waste stream characterization similar to livestock manures. Example industries include processors of milk, meat, food, fiber, and pharmaceuticals, among others. Some of these industries already recover methane for energy.

\subsection{Methane Recovery and the Climate Change Action Plan}

As a portion of the methane emission reduction component of the Climate Change Action Plan ${ }^{3}$ announced in 1993, the US Environmental Protection Agency (USEPA) and the US Departments of Energy (USDOE) and Agriculture (USDA) will expand a voluntary pollution prevention program with the livestock industry. In the voluntary AgSTAR program, a livestock producer will agree to explore profitable methane reduction activities by signing a Memorandum of Understanding (MOU). Under the MOU, producers will survey farm facilities to identify profitable opportunities to capture and use methane. AgSTAR producers will install systems for the recovery and use of methane only where it is profitable to do so.

Ignoring caged layer poultry, AgSTAR market penetration estimates indicate that between four and five thousand dairy and swine farms could economically justify implementation of anaerobic digestion from energy production offsets alone. Assuming an average of 100kW per facility, this rate of market penetration could add $400-$ to $500-\mathrm{mW}$ of distributed power to the grid using current engine/generator technologies.

AgSTAR will address two significant barriers that limit on-farm methane recovery: (1) lack of familiarity with and understanding of available technologies; and (2) lack of effective

3 Clinton and Gore (1993) Climate Change Action Plan. Executive Office of the President, Washington, DC. financing mechanisms to implement those technologies.

AgSTAR is designed to reduce the cost of methane recovery technologies by increasing demand and by minimizing upfront expenses during initial project assessment. A integral element is educational outreach in the form of workshops, comprehensive workbooks, and "field-day" tours that will explain the anaerobic digestion approach to the agricultural community and others.

AgSTAR will also support practical demonstration projects on working farms to help increase the rate of market penetration of this technology by illustrating the merits of anaerobic digesters to livestock producers and others. USEPA and USDOE are scheduled to conduct additional research, development, and deployment activities. Their objective is to expand the universe of economically justifiable opportunities across the livestock production sector by developing more cost-effective technologies for a wider range of facility sizes. Activity areas may include: digestion processes and systems, biogas recovery, handling and utilization systems, and effluent utilization systems.

AgSTAR spans three major livestock groups (dairy, swine, and poultry), and cost-effective options exist for each of these operations. The potential for sizable program participation is apparent. USEPA, USDOE, and USDA will identify groups, organizations, and other institutions that can promote the program to producers at the county, state, regional and national levels. These agencies are committed to making an extensive effort to identify federal, state, local, and private lending institutions that will develop financing mechanisms to assist producers in implementing cost-effective technologies. 


\subsection{INTRODUCTION TO ANAEROBIC DIGESTION}

Biogas is produced by the anaerobic (without oxygen) digestion of various types of organic plant and animal materials by bacteria in an airtight reactor commonly called a digester.

Although some effort has focused on the anaerobic digestion of poultry manures, the manures from dairy and swine operations tend to be more suitable for farm-based energy conversion. This is true because dairy and swine manure management systems are often liquid- or slurry-based, which simplifies the necessary manure movement. Also, poultry manures contain a higher concentration of fine solids which can quickly fall out of suspension unless continuously agitated. If not kept in suspension, these solids can reduce reactor volume and its ability to produce biogas.

Biogas produced by the anaerobic digestion process is quite similar to "natural" gas as it is extracted from the wellhead. Depending on the digestion process, the methane content of biogas generally ranges between 55 and 70 percent $(500$ to $650 \mathrm{Btu}$ per standard cubic foot). The remaining composition is primarily carbon dioxide, with trace quantities (parts per million) of corrosive hydrogen sulfide.

Conventional anaerobic digesters, as will be explained in greater detail, are commonly designed to operate in either the mesophilic temperature range ( 20 degrees $C$ to 45 degrees $C$ or 68 degrees $F$ to 113 degrees $F$ ) or thermophilic temperature range (45 degrees $C$ to 60 degrees $C$ or 113 degrees $F$ to 150 degrees F). There are usually two reasons why these temperature ranges are preferred. First, a higher loading rate of organic materials can be processed, and because shorter retention times are associated with higher temperatures, increased outputs for a given digester capacity result. Second, a higher temperature increases the destruction of pathogens present in raw manure. Anaerobic digestion can also occur in the psychrophilic temperature range lless than 20 degrees $C$ or 68 degrees $F$ ), but this range has not been as extensively evaluated by the research community.
Biogas produced by anaerobic digestion is suitable for use in engine/generators to produce electricity, boilers to produce hot water and steam used for sanitary washing, or in gas-fired absorption chillers used for refrigeration. ${ }^{1,2}$ When biogas is used to produce electricity, there is the added potential for harvesting thermal energy from the engine's exhaust and cooling systems. Some digesters successfully compress the biogas to operate light-duty farm equipment as well.

\subsection{US FARM-BASED ANAEROBIC DIGESTION PRACTICES}

The nation's first farm-based digester was initiated as a result of a now familiar problem-urban encroachment. McCabe Fárm's built most of its hog production facilities between 1951 and 1953 on a rural site outside of the Town of Mt. Pleasant, lowa. By 1970, the town had expanded to the farm's border, and the McCabe family had to develop an odor-free system of managing swine waste. Initially, the McCabe's converted their existing anaerobic lagoon into an aerobic system by adding an aerator. However, the buildup of organic matter over the winter took 6 to 8 weeks to stabilize in the spring, during which time a significant odor problem occurred. Chemicals were added to the aerobic lagoon in early spring one year, and it helped control odors but did not eliminate them.

A new system was needed that would deodorize the manure all year and allow it to be spread according to the farm's schedule during good weather. With the assistance of the county Extension Service and others, Harold "Wiz" McCabe found what appeared to be a satisfactory solution in a theoretical article describing the anaerobic digestion of swine manure. The process promised to provide a

$1 \quad$ Walsh et al. (1988) Handbook on Biogas Utilization. Southeastern Regional Biomass Energy Program, Tennessee Valley Authority, Muscle Shoals, AL.

2 Wiltsee (1994) Heat-Activated Cooling Devices: A Guidebook for General Audiences. Southeastern Regional Biomass Energy Program, Tennessee Valley Authority, Muscle Shoals, AL. 
gas that could be easily disposed of and also would produce a stabilized sludge that could be spread anywhere. "Wiz" was an innovator and master mechanic, and he undertook a crash course in the design and construction of a complete mix anaerobic digester. It took two years to locate and install the reactor, fabricate heat exchangers from old dairy equipment, convert an old dairy 10-horsepower upright boiler to operate on both biogas and propane, install the necessary control and safety equipment, and to put all of the pieces together. In early May 1972, the digester was seeded with 6,000 gallons of sludge from the town's municipal waste digester and two hours of waste flow from the swine facility. Over the next few days, digester seeding continued on a planned schedule. On 10 May, the fifth day after digester inoculation, excess biogas tripped a relief valve and the first farm-based digester in the United States (US) came to life.

During the energy crises of the mid- and late1970 's, the search for alternative energy resources led to investigation of small- and medium-scale anaerobic digesters developed in India and China to determine whether these technologies were directly transferable to farms in the US. Unfortunately, while these technologies are useful in providing fuel for cooking and lighting in developing economies, the majority of the 6-8 million digesters installed in Asia are much too small to be useful to most American farmers. For example, the typical small-scale digester daily produces about the same amount of energy as contained in one gallon of propane ${ }^{3}$.

The greater energy requirements of the largersized American livestock operations led to the design and installation of several digesters using model municipal sewage treatment plant technology. These demonstration projects represented a transfer of state-of-the-art sewage treatment plant technology and were the first generation of complete mix digesters installed for agricultural application. Although complete mix digesters can operate in the thermophilic temperature range, the

3 Volunteers in Technical Assistance (1979) Design and Construction of a Three-Meter Anaerobic Digester. VITA, Mt Ranier, MD. demonstration projects at facilities such as the Washington State Dairy Farm in Monroe ${ }^{4}$ operated only in the mesophilic temperature range. At the Monroe project, the digester was sized for the manure volume produced by a milking herd of 180 to 200 Holstein cows. Although these early complete mix digesters generally produced biogas at the target design rate, they suffered from high capital costs and from significant operation and maintenance requirements. In practical application on the farm, the issues of solids settling, scum formation, and grit removal often presented major problems.

Today's complete mix digesters typically handle manure with a low solids content and generally can handle substantial manure volumes. The reactor is a large, vertical, poured concrete or steel circular container. The manure is collected in a mixing pit by either a gravity-flow or pump system. The total solids percentage can be diluted, and the manure can be pre-heated before it is introduced to the digester reactor. The manure is deliberately mixed within the digester reactor. The mixing process creates a homogeneous substrate which prevents the formation of a surface crust and keeps solids in suspension. Mixing and heating often improve digester efficiency with an average retention time as low as 10 to 20 days.

A fixed cover is placed over the complete mix digester reactor to maintain anaerobic conditions and to trap the methane that is produced. The methane is removed from the digester, processed, and transported to the site of end use application. The most common application for methane produced by the digestion process is electricity generation using a modified internal combustion engine. Both the digester reactor and the mixing pit are heated with waste heat from the engine cooling system. As already mentioned, complete mix digesters operate at either the mesophilic or thermophilic temperatures ranges. Lower temperatures reduce the rate of methane

4 Coppinger, et al. (1980) Economics and operational experience of a full-scale anaerobic dairy manure digester. IN Biogas and Alcohol: Fuels Production, ed. J. Goldstein, The JG Press, Emmaus, PA. 
production, and consequently, a digester operated in the mesophilic range requires a longer average manure retention time and a larger tank. Complete mix digester volumes range considerably from about 3500 cubic feet to 14,000 cubic feet. This represents daily capacities of about 25,000 gallons to 100,000 gallons of manure per digester. Larger volumes are usually handled by multiple digesters.

By the late-1970's researchers at Cornell University ${ }^{5}$ were able to reduce the capital costs and the operational complexities associated with the early complete mix digesters by using a simple extension of Asian anaerobic digestion technology. These "plug flow" digesters were adopted with some success in the cooler climate of the Northeast, where farms primarily use scraping systems for manure removal. The 1979 project at the Mason Dixon Dairy Farms in Gettysburg, Pennsylvania was the first plug flow digester operated on a commercial farm. At the Mason Dixon project, the plug flow digester was originally sized for a manure volume produced by a milking herd of 250 Holstein cows.

The basic plug flow digester design is a long linear trough, often built below ground level, with an air tight expandable cover. The manure is collected daily and added at one end of the trough. Each day a new "plug" of manure is added, slowly pushing the other manure down the trough. The size of the plug flow system is determined by the size of the daily "plug". As the manure progresses through the trough, it decomposes and produces methane that is trapped in the expandable cover. In order to protect the flexible cover and to maintain optimal temperatures, some plug flow digesters are enclosed in simple greenhouses or insulated with a fiberglass blanket. The retention time, the total time that manure spends inside the digester as it flows from one end to the other, is from 20 to 30 days depending on the digester temperature. An often vital component of a plug flow digester is the mixing

5 Jewell et al. (1979) Low cost methane generation on small farms. Paper at Third Annual Symposium on Biomass Energy Systems, Golden, CO. pit. A mixing pit allows the percent total solids of the manure to be adjusted by dilution with water. Many systems use a mixing pit with a capacity roughly equal to one day's manure output to store manure before being added to the digester.

Plug flow digesters operate at either the mesophilic or thermophilic temperature ranges. The amount of methane produced depends on the quantity of manure and the average retention time in the trough. Lower temperatures will slow the rate of digestion, which will require a longer retention time, and consequently, a larger, more expensive trough. Higher temperatures will increase the rate of digestion, which allows a shorter retention time and a smaller, less expensive trough. Energy for heating the digester is available in the waste heat from the exhaust and cooling system of an internal combustion engine/generator powered by the biogas produced in the digester.

The complete mix and plug flow digestion technologies are not suited for use on farms that use hydraulic flushing systems for manure removal and anaerobic lagoons for waste treatment. An anaerobic lagoon is an increasingly popular method used to store and treat manure. A properly designed and operated lagoon system, where the manure retention time exceeds sixty days, will produce significant quantities of methane. In the early1980 's, the concept of using a floating cover that collects biogas as it escapes from the surface of an anaerobic lagoon emerged. The first floating cover that recovered biogas from an anaerobic lagoon operating in the psychrophilic range was at the Royal Farm operation in Tulare, California ${ }^{6}$. The Royal Farm's digester used the manure from a 1,600sow farrow-to-finish farm.

The North Carolina Energy Division and North Carolina State University constructed the first full-scale covered anaerobic lagoon digester on the east coast at the Randleigh

6 Chandler, Hermes and Smith (1983) A low-cost $75-\mathrm{kW}$ covered lagoon biogas system. Paper at Energy from Biomass and Wastes VII, Lake Buena Vista, FL. 
Dairy in $1988^{7}$. The digester processed the wastes from 150 dairy cows. The cooperative project used funds provided by the Southeastern Regional Biomass Energy Program, the North Carolina Agricultural Research Service, and the North Carolina Dairy Foundation. The project objective was to educate dairy producers through practical demonstration and outreach about the merits of a low-cost and easily maintained digester suitable for use on farms using hydraulic flush manure management systems. The project provided information about the amount of biogas that can be recovered, along with cost information from which the economic merit of the technology can be evaluated.

The methane produced in an anaerobic lagoon is captured by placing a floating, impermeable cover over the lagoon. The cover is constructed of an industrial fabric (e.g., hypalon) that rests on solid floats laid on the surface of the lagoon. The cover can be placed over the entire lagoon or the portion of the lagoon that produces the most methane. Once the cover is installed, the methane produced under the covered area of the lagoon is trapped. The biogas is harvested using a collection manifold, such as a long perforated pipe, that is placed under the cover along the sealed edge of the lagoon. Methane is removed by the pull of a slight vacuum on the collection manifold (e.g., by connecting a suction blower to the end of the pipe) that draws the collected biogas out from under the cover and on to the end-use application.

The cover is held in position with ropes and anchored by a concrete footing along the edge of the lagoon. Where the cover attaches to the edge of the lagoon, an air-tight seal is constructed by placing a sheet of the cover material over the lagoon bank and down several feet into the lagoon, and clamping the cover (with the footing) onto the sealed bank.

Seals are formed on the remaining edges by using a weighted curtain of material that hangs vertically from the edge of the floating cover into the lagoon.

Safley and Lusk (1990) Low Temperature Anaerobic Digester. North Carolina Energy Division, Raleigh, NC.
The covered lagoon digester has several merits. First, it has good potential for widespread adoption in the United States, especially in the southeastern and southwestern regions, because most dairy and swine facilities use hydraulic flushing for manure collection and anaerobic lagoons for waste treatment. Second, the construction and management of this type of reactor is simple and straightforward when compared to complete mix and plug flow digesters. Third, the capital costs for this type of digester are considerably less than that required for the complete mix and plug flow types of conventional digesters.

Covering an anaerobic lagoon and harvesting the biogas is a simplified technology; however, the approach raises at least two significant concerns. A key issue is that digestion rate is dependent on temperature; therefore, biogas production varies seasonally if the lagoon is not externally heated. This means that methane production is greatest in the warm, summer months and lowest during the cooler, winter months. At the Randleigh Dairy, daily biogas production during the summer averaged 35 percent greater than daily production during the winter. This may make end-use applications more problematic than it is with conventional digesters which have less significant seasonal variations in methane production. Moreover, any anaerobic lagoon (covered or not) is impractical in areas with a high water table because of the potential for ground water contamination. Lagoons built into highly permeable soils must be adequately lined to prevent ground water contamination.

The Mason Dixon Farms mentioned earlier has since grown to a total herd of 2,000 milking cows and has built two additional digesters to accommodate the increased manure volume. As will be discussed in the Case Study, Mason Dixon Farms has abandoned the linear plug flow approach. The greatly simplified slurrybased "loop" digester now employed further minimizes digester construction and operating costs. This loop design enables greater convective currents in the digester, thereby avoiding the solids crusting problem commonly associated with the plug flow design. This improvement may offer great opportunity for the deployment of loop digesters at caged-layer poultry operations. 
In general, the slurry-based designs may offer the most benefits beyond their low cost to install and simplified operation. When combined with a mechanical scraping system for manure collection, there is little added water compared to hydraulic flushing. Because the organic acids are not volitilized, the methane and odor associated with manure decomposition can be minimized to the greatest extent possible.

A number of other methods for on-farm anaerobic digestion have been proposed, including variations of covered anaerobic lagoons generally referenced as Advanced Integrated Pond Systems (AIPS) ${ }^{8}$. AIPS use a submerged canopy covering a facultative pond, where the organic wastes are completely converted into methane, nitrogen, carbon dioxide, and stable residues. The submerged canopy is potentially more cost-effective than conventional covered lagoons because it is not exposed to weather and other elements. One intriguing aspect of AIPS is that digester effluent is discharged into secondary pools and is expressly used as a growth culture for algae.

Other types of anaerobic digesters discussed for farm-application, but not yet commercially used in the US, include packed reactors, upflow sludge blankets, and sequencing batch reactors. Although these technologies offer the potential for reducing the number of days required for the anaerobic process, they comparatively suffer from higher capital and operating costs, as well as a greater level of process and operational complexity than the types now in operation.

\subsection{ANAEROBIC DIGESTION AND THE ENVIRONMENT}

Growth and concentration of the livestock industry in the US creates new opportunities for the proper disposal of manures generated at dairy, swine and poultry farms. The principal

8 Oswald (1993) Ponds in the twenty-first century. Paper at 2nd International Association of Water Quality Conference on Waste Stabilization Ponds and the Reuse of Pond Effluents, Oakland, CA. pollutants from decomposing livestock manures are methane emissions, ammonia, excess nutrients and pathogens, along with biochemical oxygen demand (BOD). The major pollution problems associated with these wastes are surface and ground water contamination, and surface air pollution due to odors, dust, volatile organic acids, and ammonia. There is also concern about the contribution of methane emissions to global climate change. Consequently, manure management systems that enable pollution prevention as well as energy production are becoming increasingly attractive.

Methods of controlling agricultural non-point pollution sources are not as developed as those for point sources. Solutions to non-point problems involve land-use planning and practices that are largely the responsibility of state and local governments. Most federal efforts to control agricultural non-point sources have emphasized a voluntary, non-regulatory approach based on the implementation of best management practices (BMPs) instead of regulations. In developing BMPs, states often take economic, institutional, and technical factors into consideration.

Section 319 of the federal Clean Water Act created a program to control non-point sources of pollution and to protect ground water. Each state is required to submit an assessment of state waters not expected to meet water quality standards because of non-point source pollution. Each state is also required to develop a management program for controlling nonpoint source pollution. Most agricultural activities have been classified as non-point sources of water pollution. Livestock non-point sources of water pollution include range and pastureland, feeding and watering sites, confinement facilities and manure disposal areas. These wastes are widely dispersed and are more difficult to regulate than effluents from point sources such as sewers and pipes. Including point sources, agriculture is now alleged to be the leading source of water pollution in the country ${ }^{9}$. Many livestock

9 Weinberg (1991) EPA programs addressing animal waste management. 1991. Proceedings of a National Workshop on Livestock, Pouttry \& Aquaculture Waste 
producers believe that these figures are not accurate and are biased upwards due to sampling of only those waters known to have water-quality problems.

Increased methane concentrations in the atmosphere may have important impacts on global climate change, ground-based ozone, and stratospheric ozone. Methane is considered to be one of the most potent greenhouse gases. Each molecule of methane is estimated to have 22 times the heat trapping impact of a carbon dioxide molecule. The US Environmental Protection Agency (USEPA) estimates that the atmospheric concentration of methane is increasing at one percent per year and has more than doubled over the past two centuries ${ }^{10}$.

US livestock manures are estimated to emit about 3 million metric tons of methane annually and account for approximately 10 percent of the total US methane emissions ${ }^{11}$. Swine and dairy production facilities account for 80 percent of these emissions. The USEPA estimates about 1 million metric tons, or 33 percent of these emissions, have the potential to be profitably reduced at these farms.

With better waste management, methane from manure can be a clean, renewable source of energy. Moreover, based on life-cycle cost analysis of proven methane recovery. technologies such as slurry, covered lagoons, plug flow and complete mix digesters, an unavoidable livestock production liability can become a profit-making asset. Among waste handling systems, the potential rate of energy production from liquid-based systems is greater

\begin{tabular}{|c|c|c|c|}
\hline 10 & $\begin{array}{l}\text { Management. American Society of } \\
\text { Agricultural Engineers. } \\
\text { Safley et al. (1992) Global Methane } \\
\text { Emissions From Livestock and Poultry } \\
\text { Manure. US Environmental Protection } \\
\text { Agency (EPA } 400 / 1-91 / 048)\end{array}$ & & \\
\hline 11 & $\begin{array}{l}\text { US Environmental Protection Agency } \\
\text { (1993) Methane Emissions from Livestock } \\
\text { Manure (Chapter Six) IN Opportunities to } \\
\text { Reduce Anthropogenic Methane Emissions } \\
\text { in the United States: Report to Congress. } \\
\text { (EPA-430-R-93-012) }\end{array}$ & 13 & $\begin{array}{l}\text { Supra, Note } 11 . \\
\text { Center for Rural Affairs. Manure } \\
\text { Management in the European Pork } \\
\text { Industry. August } 1994 \text { Newsletter. } \\
\text { Walthill, NE. }\end{array}$ \\
\hline
\end{tabular}

than for solid-based systems, because liquidbased systems encourage anaerobic digestion. Once again based on USEPA estimates ${ }^{12}$, liquid-based systems (anaerobic lagoons and liquid/slurry storage) account for 40 percent of US methane emissions, while solid-based systems (pasture/range, daily spread, solid storage, and drylots) account for the remaining 60 percent.

One source ${ }^{13}$ estimates that the difference in methane emission rates between liquid- and solid-based systems is even greater. While only 28 percent of the nation's hogs are kept in facilities using anaerobic lagoons, it is estimated that these lagoon systems emit 73 percent of the hog manure methane. According to this source, manure decomposing on pastures or fields emits only about 10 percent of the potential methane into the atmosphere. By contrast, emission rates for manure that decomposes in water can be as high as 90 percent of the total methane potential.

There are no formal federal rules or regulations aimed at reducing methane emissions from livestock manures. However, as part of the strategy for stabilizing global methane concentrations, the USEPA, and the US Departments of Energy (USDOE) and Agriculture (USDA) are identifying and evaluating various options for reducing a variety of methane emissions. As discussed in Section 5, these organizations are currently developing voluntary initiatives to capture methane produced by livestock manures and convert it into an on-farm alternative energy resource. 


\subsection{ECONOMIC EVALUATION OF ANAEROBIC DIGESTION}

Given that there are a number of anaerobic digestion technologies available, it is useful to evaluate them using objective economic criteria. Objective economic criteria allows technology options to be ranked in terms of relative cost-effectiveness so that a rational decision can be made between the competing choices.

This section presents a series of pro forma economic evaluations of three types of anaerobic digesters commonly found on dairy and swine farms. The technologies include covered lagoon, plug flow, and complete mix anaerobic digesters. The digesters were assumed to generate electricity as the end-use application of biogas manufactured from the anaerobic process. These evaluations were employed, in part, to develop regression models which can be used to estimate digester cost and internal rate of return as a function of herd size. The evaluations also were used to illustrate the importance of maximizing coproduct utilization and other offsets which can result from technology adoption. This Section provides a narrative discussion of these evaluations, and a Technical Appendix provides the computer print-outs.

\subsection{DATA AND METHODS}

The first objective of this Section is to develop regression models that can be used to estimate digester cost and internal rate of return as a function of herd size. The types of digesters analyzed are those that are commonly found operating on dairy and swine farms today: covered lagoon, plug flow, and complete mix. Each technology was evaluated using three different herd sizes. Dairy farms were further differentiated by the use of two manure collection scenarios. The first is parlor only, resulting in relatively low manure collection of about 15 percent of the total farm manure generated (i.e., only the manure flushed from the milking parlor). The second collection scenario is apron and parlor, which results in a high manure collection of about 55 percent of total farm manure (i.e., the 15 percent from the milking parlor plus 40 percent from the feed apron). All swine manures were assumed to be collected. Although plug flow digesters are operating on swine farms, they were analyzed only on dairy farms under the high manure collection scenario. Thus, a total of 21 digesters were evaluated under seven specific scenarios. All of the basic system data used in the analyses were drawn from the US Environmental Protection Agency ${ }^{1}$ (USEPA) and are listed in Table 3.1.1. Some of the USEPA assumptions were modified during the pro forma modeling, as will be noted later.

A second objective of this section is to illustrate the importance of maximizing coproduct utilization and other offsets made available by adopting anaerobic.technology. Once again, the types of digesters analyzed were covered lagoon, plug flow, and complete mix. Each digester type was evaluated under two specific scenarios. The first scenario accounted for a full revenue stream, which includes savings from on-farm electricity and heat recovery offsets, surplus electricity sales, manure disposal savings, and the sale of digested solids. The second scenario evaluated each digester technology, accounting only for savings from on-farm electricity offsets and surplus electricity sales. All of the basic system data used were drawn from a Western Regional Biomass Energy Program ${ }^{2}$ (WRBEP) study, and are also listed in Table 3.1.1. Some WRBEP assumptions were modified during the modeling, as will also be noted later.

To accomplish these two objectives, the basic system data and additional macro variables, to be detailed later, were linked into CashFlow, a model that provides a summary of primary

1 US Environmental Protection Agency (1993) Methane Emissions from Livestock Manure (Chapter Six) IN Opportunities to Reduce Anthropogenic Methane Emissions in the United States: Report to Congress. EPA-430-R-93-012.

2 Whittier, et. al (1993) Energy Conversion of Animal Manures: Feasibility Analysis for Thirteen Western States. Western Regional Biomass Energy Program, Golden, CO. 


\section{TABLE 3.1.1 ANAEROBIC DIGESTION OF LIVESTOCK MANURES DATATABLE}

MACRO VARIABLES FOR CashFlow MODEL

$\begin{array}{lrl}\text { enter } & 1.5 & \% \text { Real Growth Rate in O\&M Expenses } \\ \text { enter } & 0.0 & \% \text { Real Growth Rate in Energy Expenses } \\ \text { enter } & 8.5 & \% \text { Real Discount Rate } \\ \text { enter } & 40.0 & \% \text { Combined Tax Rate } \\ \text { enter } & 0 & \begin{array}{l}\text { Depreciation of System Capital Cost Method } \\ \text { enter 1 for SL or O for 150\% DB }\end{array} \\ \text { enter } & 7-\text { Year 150\% } & \text { Tag Line for Depreciation Line-Item in CashFlow }\end{array}$

Dairy Farms w/ Electricity Generation \& Low Manure Collected (15\%)

\begin{tabular}{|c|c|c|c|c|c|c|c|c|}
\hline SYSTEM & H NAME & HEAD & SIIING & TKEY & sum. & $\mathrm{aO} \& M$ & aSAV & PLIFE \\
\hline DCLEL250 & Dairy Covered L & 250 & 15,000 & 34,600 & 49,600 & 600 & 4.400 & 15 \\
\hline DCLEL500 & Dairy Covered L & 500 & 15,000 & 47,800 & 62,800 & 1,200 & 8,700 & 15 \\
\hline DCLEL1000 & Dairy Covered L & 1000 & 15,000 & 73,700 & 88,700 & 2,300 & 17,400 & 15 \\
\hline DCMEL250 & Dairy Complete & 250 & 15,000 & 61,500 & 76,500 & 400 & 2,300 & 20 \\
\hline DCMEL500 & Dairy Complete & 500 & 17,900 & 75,000 & 92,900 & 800 & 4,700 & 20 \\
\hline DCMEL1000 & Dairy Complete & 1000 & 23,200 & 98,900 & 122,100 & 1,700 & 9,300 & 20 \\
\hline
\end{tabular}

Dairy Farms w/ Electricity Generation \& High Manure Collected (55\%)

\begin{tabular}{|c|c|c|c|c|c|c|c|c|}
\hline SYSTEM & $\therefore$ NAME & FEAD & S़IXING & TKEY & sum & $20 \& M$ & aSAV & PLIFE \\
\hline DCLEH250 & Dairy Covered L & 250 & 15,000 & 54,500 & 69,500 & 2,100 & 10,600 & 15 \\
\hline DCLEH5OO & Dairy Covered L & 500 & 15,000 & 84,800 & 99,800 & 4,200 & 21,300 & 15 \\
\hline DCLEH1000 & Dairy Covered L & 1000 & 18,100 & 145,700 & 163,800 & 8,500 & 42,600 & 15 \\
\hline DCMEH250 & Dairy Complete & 250 & 24,000 & 93,400 & 117,400 & 1,500 & 8,600 & 20 \\
\hline DCMEH5OO & Dairy Complete & 500 & 31,500 & 136,700 & 168,200 & 3,100 & 17,100 & 20 \\
\hline DCMEH1000 & Dairy Complete & 1000 & 48,400 & 213,400 & 261,800 & 6,100 & 34,300 & 20 \\
\hline DPFEH 250 & Dairy Plug Flow & 250 & 18,800 & 79,000 & 97,800 & 1,100 & 6,200 & 15 \\
\hline DPFEH500 & Dairy Plug Flow & 500 & 24,700 & 105,400 & 130,100 & 2,200 & 12,500 & 15 \\
\hline DPFEH1000 & Dairy Plug Flow & 1000 & 35,500 & 154,800 & 190,300 & 4,400 & 24,900 & 15 \\
\hline SDPFE300 & SD Dairy Plug F & 300 & NA & 144,047 & 144,047 & 3,269 & 15,122 & 15 \\
\hline SDPFA300 & SD Dairy Plug F & 300 & NA & 144,047 & 144,047 & 3,269 & 27,720 & 15 \\
\hline TXCLA500 & TX Dairy Cover & 500 & NA & 128,082 & 128,082 & 3,813 & 18,784 & 15 \\
\hline CACLE1000 & CA Dairy Cover & 1000 & NA & 201,466 & 201,466 & 7,625 & 32,291 & 15 \\
\hline CACLA1000 & CA Dainy Cover & 1000 & NA & 201,466 & 201,466 & 7,625 & 44,243 & 15 \\
\hline
\end{tabular}

Swine Farms w/ On-Farm Electricity Generation \& All Manure Collected (100\%)

\begin{tabular}{|c|c|c|c|c|c|c|c|c|}
\hline SYSTEM. & NAME & HEAD & SITING & TKEY & sum & $a O \& M$ & aSAV & pLIFE \\
\hline SCLEH500 & Snine Covered & 500 & 8,500 & 40,400 & 48,900 & 1,100 & 6,100 & 15 \\
\hline SCLEH1000 & Suine Covered & 1000 & 11,600 & 60,100 & 71,700 & 2,300 & 12,300 & 15 \\
\hline SCLEH5000 & Suine Covered & 5000 & 40,600 & 209,000 & 249,600 & 11,300 & 61,300 & 15 \\
\hline SCMEH500 & Suine Complet & 500 & 16,700 & 69,300 & 86,000 & 1.000 & 6.400 & 20 \\
\hline SCMEH1000 & Suine Complet & 1000 & 21,400 & 90,600 & 112,000 & 2,000 & 12,700 & 20 \\
\hline SCMEH5000 & Snine Complet & 5000 & 53,900 & 238,500 & 292,400 & 10,300 & 63,700 & 20 \\
\hline NBCME10K & NB Swine Com & 10000 & NA & 249,753 & 249,753 & 9,447 & 36,575 & 20 \\
\hline NBCMA1OK & NB Swine Com & 10000 & NA & 249,753 & 249,753 & 9.447 & 42,465 & 20 \\
\hline
\end{tabular}


investment merit statistics. The investment merit statistics of interest are Net Present Value (NPV), Internal Rate of Return (IRR), Simple Payback Period (SPP), and Cumulative Cash Flow (CCF). All of the investment merit statistics are related, and for comparative purposes they will be benchmarked later.

Before proceeding, some preliminary economic concepts should be briefly discussed. The interrelationship of investment merit statistics is at the center of economic evaluation. The most readily understood statistic is cash flow. Cash flow is a schedule of annual net profit lor loss) resulting from an investment and can take into account such factors as amortization or the inflation rate for displaced fuels. The important point about cash flow is that "less money spent" is equal to "more money made". However, cash flow does not account for the time value of money. The time-value of money concept asserts that a current dollar is more valuable than a future dollar. To assess true profitability, cash flows must be adjusted by the discount rate in order to put dollars into a consistent present value. The discount rate can be interpreted as the interest rate anticipated on an alternate investment opportunity, against which the original opportunity is compared in order to evaluate the financial consequence of going with the original. The interrelationship of these investment merit statistics is discussed below.

Simple Payback Period (SPP) is often used as a criterion for determining investment acceptability. From cash flow, a SPP for the investment can be quickly calculated. SPP is the "break-even" length of time necessary to recover the initial investment through positive cash flow. Many businesses will only undertake investments with a two-year SPP. However, while payback may be useful in measuring the liquidity of an investment, it offers no real insight on profitability because the analysis is incomplete. Neither the time value of money, nor positive cash flow occurring after the payback period is accounted for. Hence, for mutually exclusive projects with equal cash flows, the project with an infinite lifetime would receive the same ranking as a project with a very short lifetime if both had the same payback period.
Net Present Value (NPV) is an investment merit statistic that accounts for the time value of money by describing the present worth of an investment in dollars. It is calculated by the compound discounting of the investment's annual cash flow with a specified discount rate, and then totaling the discounted cash flows over the investment life to arrive at its net value. If NPV is a positive figure, the investment provides a greater return than the alternate choice assumed by the discount rate. If the NPV is a negative figure, the alternate presents the better opportunity. If NPV equals zero, it is said the choices are indifferent. When there is more than one competing investment, the higher NPV is preferred. However, in a capital rationing situation, NPV has an inherent bias in favor of large projects.

Internal Rate of Return (IRR) is related to NPV: it is the percentage figure of the discount rate that yields a zero NPV. IRR allows direct comparison between the returns offered by different investment opportunities. If the IRR from an investment is greater than the discount rate, the investment is more worthwhile than the alternate choice. However, IRR suffers in two areas. First, if a project has a cash outflow at its end, multiple rates of return exist. While this is not the case with the data analyzed, the situation occurs, for example, in circumstances where there are abandonment costs. Second, a bias is introduced in the implicit assumption that all positive cash flows are reinvested over the remaining project life at the calculated IRR. "This may be an unrealistic assumption, especially for projects with relatively high Internal Rates of Return. While this does not affect the decision to accept or reject a project, it does affect the relative ranking of projects when comparing their relative profitability." ${ }^{3}$

Although the IRR and NPV methods will lead to the same decision whether to accept or reject a project, they can provide conflicting clues when the decision is a choice between mutually exclusive projects. That is, one

3 McGuigan, J. \& Moyer, R. (1975) Managerial Economics: Private and Public Sector Decision Analysis. The Dryden Press, Hinsdale, IL. 
project can have a higher IRR but lower NPV. This problem arises because the IRR is the implied reinvestment rate in the IRR method, while the discount rate is the implicit reinvestment rate used in the NPV method. NPV is generally superior because reinvestment will likely occur at a rate close to the cost of capital.

After estimating the investment merit statistics with CashFlow, an additional step was required to accomplish the first stated objective: estimate digester cost and IRR as functions of herd size. Two simple (twovariable) linear regression models were developed for each of the seven digester scenarios. From econometric theory, a simple regression model is used for testing hypotheses about the relationship between a dependent variable $(y)$ and an explanatory variable $(x)$ and for making predictions. The system capital cost information and IRR estimates provided by CashFlow for each herd size were aggregated for each of the seven digester scenarios. Simple regression analyses were then performed to evaluate the relationship between herd size and capital cost and herd size and IRR for each digester scenario.

The estimating equations were evaluated for goodness of fit and correlation. Theoretically, the closer the observations fall to the regression line, the greater the variation "explained" by the estimating equation. The coefficient of determination $\left(R^{2}\right)$ is defined as the proportion of the total variation in the dependent variable (cost or IRR in this case) explained by the regression of those factors on herd size. A correlation coefficient (the square root of $R^{2}$ ) measures the degree of association between two variables (herd size and digester cost or IRR) and whether the variables move in the same (positive correlation) or in the opposite direction (negative correlation). Because it is assumed that there is a positive relationship between digester cost and IRR as a function of herd size, the models were developed with these expectations. Correlation between variables does not imply causality or dependence between them. After testing the significance of the parameter estimates using the $t$ distribution, the regression analyses were then used for predicting the capital cost of installing an anaerobic digester and the minimum herd size required for a digester's profitable operation. Because of the small number of samples (three) for each digester scenario, this information should only be used with a high degree of caution.

As noted earlier, some macro variables, those general assumptions shared by all projects, were used in the CashFlow analyses. These assumed macro variables are listed in Table 3.1.2 and include: real growth rate in operation and maintenance expenses, real growth rate in energy expenses, percent real discount rate, percent combined tax rate, and depreciation of system capital costs method. The values for real growth rate in operation and maintenance expenses and real growth rate in energy expenses were a priori choices. A zero real growth rate in energy prices was used in evaluating the treatment technologies to account for a hypothetical "worst-case". It was assumed that the labor and materials required for operation and maintenance rose at a positive real rate above energy prices. The real rate of growth in the employment cost index has averaged about the same as the general rate of inflation since 1990 .

\begin{tabular}{|c|c|}
\hline TABLE 3.1.2: $\begin{array}{c}\text { Macro Varia } \\
\text { Model }\end{array}$ & Tes Used in CashFlow \\
\hline Real Growth Ratelino\& & 1:2Percent \\
\hline Real Growth Rate in Energy & 0.0 Percent \\
\hline Real piscount Rate: & 8.5 Percent \\
\hline Marginal Tax Rate & $\begin{array}{l}\text { 40.0 Percent } \\
7-\text { Year 150\% DB-GDS }\end{array}$ \\
\hline
\end{tabular}

Although all of the system data for the analyses were taken directly from the USEPA and WRBEP studies without question as to its veracity, a number of different key assumptions were used with the data herein.

The first area of difference relates to project life. Both USEPA and WRBEP estimated that the project life of all anaerobic digestion technologies is 10 years. As will be shown in Section 4, there are a number of operating onfarm digesters that have demonstrated practical lives longer than a 10 year period. Based on this objective evidence, it was assumed that well designed and maintained covered lagoon and plug flow digesters have a project life of no less than 15 years. Because the tank of a 
years. In the real world, the actual project lifetime may far exceed these values for well designed and maintained digesters.

The second area of difference relates to discount rate. Without belaboring the point, the choice of a discount rate is essential to the outcome: what may appear to be justified with a low discount rate may be imprudent at a higher rate. There are a number of problems with estimating a discount rate for farm-based technologies. Basic questions arise; for example, what is a true discount rate for livestock producers? What level of risk, and hence discount rate, does the investment in anaerobic digestion technology really represent? The range could lie between the yield of the "risk-free" investments made by the Treasury Department to that of a more speculative "junk" bond. Finally, private sector externalities are not accounted for within the discount rate. Mitigation of environmental externalities can be a major factor leading to investment in anaerobic digestion technology.

WRBEP estimated the nominal project discount rate to be 9 percent, with an estimated inflation rate of 5 percent. USEPA settled on a nominal project discount rate of 12 percent, using the "rule of thumb" that businesses establish a hurdle rate for new initiatives at the prime rate of interest plus 6 percent. Moreover, WRBEP and USEPA estimates were in nominal rates, which include current and expected inflation rates, instead of the real discount rate economists desire, that is, one which factors out inflation. Since it is beyond the scope of this paper to further delineate the "true" discount rate for livestock producers, an appropriate discount rate here was assumed per USEPA (prime rate of interest plus 6 percent). This helps to simplify the issue of how to incorporate investment risk. It was also assumed in the analyses presented here that there is a constant inflation rate equal to 3.5 percent annually. This rate is about the same as the three-year average percentage change in the implicit price deflator reported for domestic purchases of goods and services. The average prime rate of interest for the past three years has been 6.0 percent. Because the inflation rate was small, by subtraction, the real project discount rate is approximately 8.5 percent 6 percent +6 percent -3.5 percent
$=8.5$ percent). The Federal Reserve Board took action in mid-1994 to increase the prime interest rate in the hope that it would dampen the threat of inflation. At the time of publication, the nominal prime interest rate was equal to 8.5 percent. Using the assumptions above, the implied project real discount rate is approximately 11 percent.

Another significant difference in the assumptions used is in the area of depreciation of capital equipment. Following the expiration of the business and energy tax credits with the passage of the federal Tax Reform Act of 1986, depreciation of capital equipment is one of few incentives which can legitimately increase the economic performance of anaerobic digestion technologies. Both USEPA and WRBEP used a 10 year straight line depreciation method. After review of Internal Revenue Service publications ${ }^{4}$, a seven-year $150 \%$ Declining Balance General Depreciation System (150\% DB-GDS) election offered under the Modified Accelerated Cost Recovery System (MARCS) was used. The depreciation method and time period is one election under the MARCS. Although it appears that the $200 \%$ Double DB-GDS can also be used in situations involving ownership by an unrelated party, the $150 \%$ DB-DGS is directed toward farm rather than non-farm property classes. As with all matters related to taxes, a competent accountant or attorney should be consulted to maximize all legitimate incentives that exist for specific situations.

There were a number of other smaller-impact changes in the driving assumptions. USEPA assumed a zero salvage value at the end of project life, and WRBEP assumed a salvage value of 10 percent for complete mix digesters and 20 percent for plug flow or covered lagoon digesters. This study assumed a zero salvage value per USEPA. USEPA assumed a combined tax rate of 40 percent, and WRBEP assumed a combined tax rate of 20 percent. To be conservative in estimating tax rates, this study assumed a 40 percent combined tax rate per USEPA. All financial exchanges were

\footnotetext{
4 IRS Publication 534: Depreciation and IRS Publication 946: How to Begin Depreciating Your Property.
} 
To be conservative in estimating tax rates, this study assumed a 40 percent combined tax rate per USEPA. All financial exchanges were assumed to be "cash-and-carry" with no budget constraints. USEPA assumed the same. WRBEP assumed that the investment would be financed with an interest rate of 9.25 percent following a down payment of $1 / 3$ of the total project costs. The last difference in assumptions is in the use of the end-of-year convention. Herein, it was assumed that all project capital costs were incurred during Time 0 . The issue may be esoteric, but it is related to estimating NPV and IRR, because project capital costs accounted for in years following Time 0 are discounted.

\subsection{DAIRY FARM DIGESTERS WITH ELECTRICITY GENERATION AND LOW MANURE COLLECTED}

This section evaluates the investment merit of two types of anaerobic digesters used on dairy farms with herd sizes of 250, 500 and 1000 cows. Herd size refers to the number of milking cows having the average weight of 1,400 pounds. Dairy farms used two manure collection scenarios, apron only collection and apron and parlor collection. The scenario evaluated in this section was apron only, which resulted in a low manure collection of 15 percent of the total manure volume generated on the farm. For the purpose of estimating biogas recovery rates, the covered lagoon digester was assumed to be located in Erath County, Texas. The digester capital costing information represented the total "turn-key" cost of all materials, labor and engineering services required to bring a project on-line. The value of the digester was a function of how the energy was used, in other words, the direct energy costs avoided by the farmer. No credit was assumed for reducing environmental externalities. The assumed value of each digester was established by the amount of electricity generated and heat reclaimed from the engine/generator that was used on-farm as an offset for currently-purchased power utilized for milk chillers, fan and pump motors, and other equipment. On-farm water heating and milk cooling requirements can also be met with commercially available biogas-fired heaters and chillers. In determining the avoided cost of purchased power, the electricity rate used was representative of rates found in Erath County, Texas. Annual operating and maintenance costs were used as provided.

\subsubsection{0-HEAD DAIRY FARM}

Table 3.2.1 provides the investment merit statistics for a herd of 250 dairy cows. As mentioned earlier, a positive NPV indicates that a project is cost-effective. The NPV data indicates that neither the covered lagoon nor the complete mix digester was cost-effective, given the assumptions used. Graphic evaluation of the other investment merit statistics for the two treatment techniques provides a SPP of slightly over 13 years for the covered lagoon digester $\underline{v}$. more than 20 years for the complete mix digester (Figure 3.2.1). There were two sensitivity analyses performed on the two treatment choices. The first determines NPV to real discount rate, which will find whether there is a positive discount rate yielding a positive NPV. Figure 3.2.2 reveals that, under this scenario, the real discount rate must be less than 2.5 percent if the covered lagoon digester is to be costeffective. The complete mix digester had no positive-valued real discount rate that would indicate investment merit. The second sensitivity analysis determined IRR to project life. This sensitivity reveals the time period required to recover investment and is indicated by crossing the established hurdle rate in "discounted" dollars; it can be thought of as providing a project's discounted payback period (DPP). As shown in Figure 3.2.3, because the NPV for both digesters is negative, neither cross the established hurdle rate during its project lifetime.

\begin{tabular}{|c|c|c|}
\hline TABLE 3.2 .1 & Covered Lagoon & Complete $M x x$ \\
\hline $\mathrm{NP}$ & $(16545)$ & $(43 ; 782)$ \\
\hline IRR (\%) & & (4.9) \\
\hline Sppivears & 133 & $>200$ \\
\hline $\operatorname{CCF}(\$)$ & 3,834 & $(23,850)$ \\
\hline
\end{tabular}

\subsubsection{0-HEAD DAIRY FARM}

Table 3.2.2 provides the investment merit statistics for a herd of 500 dairy cows. As mentioned earlier, a positive NPV indicates that a project is cost-effective. The NPV data in Table 3.2.2, once again, reveals that neither the covered lagoon nor the complete mix 
digesters has investment merit, given the assumptions used. In Figure 3.2.4, a graphic evaluation of the other investment merit statistics for the two treatment techniques provides a SPP of about 8.5 years for the covered lagoon digester $\underline{v}$. more than 20 years for the complete mix digester. With respect to the two sensitivity analyses conducted, NPV to real discount rate (Figure 3.2 .5 ) reveals that the real discount rate must be less than 6.5 percent for the covered lagoon digester to be cost-effective. The complete mix digester had no positive-valued real discount rate that would indicate investment merit. The second sensitivity analysis of IRR to project life (Figure 3.2.6) demonstrates that the period required to recover investment costs as indicated by crossing the established hurdle rate does not occur during the project lifetimes.

\begin{tabular}{|c|c|c|}
\hline TABLE 3.22 & Covered Lagoon & Complete Mix \\
\hline NPV $\{\$\}$ & $(7,744)$ & $(44,325)$ \\
\hline IRR (\% & & (1.5) \\
\hline SPP (years) & 8.5 & $>20.0$ \\
\hline $\operatorname{CCF}(\$)$ & 28,609 & $(10,439)$ \\
\hline
\end{tabular}

\subsubsection{0-HEAD DAIRY FARM}

Table 3.2.3 provides the investment merit statistics for a herd of 1000 dairy cows. The positive NPV found for the covered lagoon digester indicates that the project has merit, and project implementation would add over $\$ 80,000$ in net farm income during its life. Evaluation of the NPV data in Table 3.2.3 illustrates that the complete mix digester is still not cost-effective, given the assumptions used. Graphic evaluation of the other investment merit statistics for the two treatment techniques provides a SPP of a little more than 6 years for the covered lagoon digester $\underline{v}$. more than 18 years for the complete mix digester (Figure 3.2.7). With respect to the NPV to real discount rate sensitivity analyses conducted, Figure 3.2.8 demonstrates that in order for the covered lagoon digester not to be costeffective, the real discount rate must be more than 10.5 percent. A real discount rate of less than 1.5 percent would indicate investment merit for the complete mix digester. The second sensitivity analysis, IRR to project life (Figure 3.2.9), reveals that an 11 year time period is required to recover investment costs for the covered lagoon digester. Since the complete mix digester does not have a positive NPV, it does not cross the established hurdle rate during its project life.

\begin{tabular}{|c|c|c|}
\hline TABLE 3.23 & Covered Lagoon & Complete Mix \\
\hline NPV (\$) & $11 ; 253$ & $(44,620)$ \\
\hline $\operatorname{IRR}(\%)$ & 10.8 & 1.5 \\
\hline SPP (years) & $64:$ & 16.5 \\
\hline CCF (\$) & 80,359 & 14,754 \\
\hline
\end{tabular}

\subsubsection{REGRESSION ANALYSES OF DAIRY FARM DIGESTERS WITH ELECTRICITY GENERATION AND LOW MANURE COLLECTED}

After calculating the investment merit statistics, an additional step was required to accomplish the first stated objective: estimate digester cost and IRR as functions of herd size. This section presents the results of two simple linear regression models accomplishing this objective.

As shown in Table 3.2.4, the cost function for a covered lagoon digester indicates that all points lie on the function's regression line. The cost function correlation coefficient suggests a perfect positive linear correlation between herd size and the cost of constructing a digester. Both the constant and coefficient " $t$ " statistics for the cost function exceed the required $t$ distribution number with 1 degree of freedom (df) at the 5 percent level of significance; therefore, they are both statistically significant at that level. The regression equation that was estimated for the cost function is graphically presented in Figure 3.2.10.

\begin{tabular}{|c|c|c|}
\hline $\begin{array}{l}\text { TABLE } \\
3.24\end{array}$ & $\begin{array}{l}\text { Cost } \\
\text { Function }\end{array}$ & $\begin{array}{l}\text { IRR } \\
\text { Function }\end{array}$ \\
\hline $\mathrm{R}^{2}$ & 1,00 & 0.96 \\
\hline & 1.00 & 0.98 \\
\hline Constant & 223.94 & -0.76 \\
\hline Coefficient $t$ & 210.50 & 5.05 \\
\hline Estimating & $36,650+52(x)$ & $-1.23+0.012(x)$ \\
\hline Equation & n: & $\because$ \\
\hline $\begin{array}{l}\text { Minimum } \\
\text { Herd Size }\end{array}$ & N/A & 784 to 890 \\
\hline
\end{tabular}

The IRR function for a covered lagoon digester indicates that the regression equation explains about 96 percent of the total variation in IRR. The remaining 4 percent is attributed to error term factors. The IRR function correlation coefficient is a near perfect positive linear correlation. However, neither the constant nor 
coefficient " $t$ " statistics for the IRR function exceeds the required $t$ distribution number with 1 degree of freedom (df) at the 5 percent level of significance; therefore, the variables are not statistically significant at that level. It is possible that a different functional form, such as a double log, would provide a better fit than the linear form. The regression equation that was estimated for the IRR function is graphically presented in Figure 3.2.11 and has a confidence level of one negative standard error incorporated. The IRR function was algebraically manipulated to provide the minimum herd size needed to operate a covered lagoon digester on a dairy farm with electricity generation and low manure collection. This was estimated to be between 784 and 890 cows at the established real discount rate of 8.5 percent.

As shown in Table 3.2.5, the cost function for a complete mix digester indicates that all points lie on the function's regression line. The cost function correlation coefficient suggests a perfect positive linear correlation between herd size and the cost of constructing a digester. Since both the constant and coefficient " $t$ " statistics for the cost function exceed the required $t$ distribution number with 1 degree of freedom (df) at the 5 percent level of significance, they are both statistically significant at that level. The estimated cost function regression equation is graphically presented in Figure 3.2.12.

\begin{tabular}{|c|c|c|}
\hline $\begin{array}{l}\text { TABLE } \\
3.2 .5\end{array}$ & $\begin{array}{l}\text { Cost } \\
\text { Function }\end{array}$ & $\begin{array}{l}\text { IRR } \\
\text { Function }\end{array}$ \\
\hline $\mathrm{B}^{2} \quad+$ & $1000 \%$ & $095 \quad \cdots$ \\
\hline $\mathbf{r}$ & 1.00 & 0.97 \\
\hline Constantt & $52: 53: 1:$ & 5.60 \\
\hline Coefficient $t$ & 33.94 & 4.34 \\
\hline Estimating & $61900+60(x)$ & $6637+0008(x)$ \\
\hline Equation & अणि। & (4) \\
\hline $\begin{array}{l}\text { Minimum } \\
\text { Herd Size }\end{array}$ & N/A & 1,838 to 1,962 \\
\hline
\end{tabular}

The IRR function for a complete mix digester indicates that the regression equation explains about 95 percent of the total variation in IRR. The remaining 5 percent is attributed to error term factors. The IRR function correlation coefficient is a near perfect positive linear correlation. However, like the covered lagoon digester earlier, neither the constant nor coefficient " $t$ " statistics for the IRR function exceeds the required $t$ distribution number with 1 degree of freedom (df) at the 5 percent level of significance. This leads to the conclusion that the variables are not statistically significant at that level. It is possible that a different functional form, such as a double log, would provide a better fit than the linear form. The regression equation that was estimated for the IRR function is graphically presented in Figure 3.2.13 and has a confidence level of one negative standard error incorporated. The IRR function was algebraically manipulated to provide the minimum herd size needed to operate a complete mix digester on a dairy farm with electricity generation and low manure collection. This was estimated to be between 1,838 and 1,962 cows at the eqstablished real discount rate of 8.5 percent.

\subsection{DAIRY FARM DIGESTERS WITH ELECTRICITY GENERATION AND HIGH MANURE COLLECTED}

This section evaluates the investment merit of three types of anaerobic digesters used on dairy farms with herd sizes of 250, 500 and 1000 cows. Herd size refers to the number of milking cows having the average weight of 1,400 pounds. Dairy farms used two manure collection scenarios, apron only collection and apron and parlor collection. The scenario evaluated in this section is apron and parlor, which results in high manure collection of 55 percent of the total manure volume generated on the farm (i.e., the 15 percent from the milking parlor plus 40 percent from the feed apron). For the purpose of estimating biogas recovery rates, the covered lagoon digester was assumed to be located in Erath County, Texas. In addition to a covered lagoon and a complete mix digester, a plug flow digester was also analyzed. For the plug flow digester, however, the USEPA assumed the solids content of the manure washed from the milking parlor was to be too low for use; consequently, only the manure found on the feed apron was used in their analysis. This USEPA assumption is probably unrealistic in the practical application and costing of plug flow digesters; some manure from the milking parlor can likely be used. The digester capital costing information represented the total "turn-key" 
cost of all materials, labor and engineering services required to bring a project on-line. The value of the digester was a function of how the energy was used, in other words, the direct energy costs avoided by the farmer. No credit was assumed for reducing environmental externalities. The assumed value of each digester was established by the amount of electricity generated and heat reclaimed from the engine/generator that was used on-farm as an offset for currently-purchased power utilized for milk chillers, fan and pump motors, and other equipment. On-farm water heating and milk cooling requirements can also be met with commercially available biogas-fired heaters and chillers. In determining the avoided cost of purchased power, the electricity rate used was representative of rates found in Erath County, Texas. Annual operating and maintenance costs were used as provided.

\subsubsection{0-HEAD DAIRY FARM}

Table 3.3.1 provides the investment merit statistics for a herd of 250 dairy cows. As mentioned earlier, a positive NPV indicates that a project is cost-effective. The NPV data in Table 3.3.1 reveals that none of the digesters has investment merit given the assumptions used. In Figure 3.3.1, a graphic evaluation of the SPP for the three treatment techniques provides a SPP of slightly over 8 years for the covered lagoon digester $\underline{v} .17$ years for the complete mix digester $\underline{v}$. more than 20 years for the plug flow digester. As earlier, there were two sensitivity analyses conducted. The first, NPV to real discount rate, finds if there is a positive discount rate yielding a positive NPV. Figure 3.3.2 reveals that in order to have investment merit, the real discount rate must be less than 6.5 percent for the covered lagoon digester and less than 1.5 percent for the complete mix digester. The plug flow digester had no positive-valued real discount rate that would indicate investment merit. The second sensitivity analysis, IRR to project life, provided a project's discounted (and therefore true) payback period (DPP). As shown in Figure 3.3.3, because the NPV for the three digesters is negative, none crosses the established hurdle rate during its project lifetime.

\begin{tabular}{|c|c|c|c|}
\hline $\begin{array}{l}\text { TABLE } \\
3.3 .1\end{array}$ & $\begin{array}{l}\text { Covered } \\
\text { Lagoon }\end{array}$ & $\begin{array}{l}\text { Complete } \\
\text { Mix }\end{array}$ & $\begin{array}{l}\text { Plug } \\
\text { Flow }\end{array}$ \\
\hline WPV (\$\$) & $(7,912) \because$ & $(43,995)$ & $(44,150)$ \\
\hline IRR (\%) & 6.2 & 1.2 & (2.4) \\
\hline SPP (years) & 8.3 & $170^{\circ}$ & $>20.0$ \\
\hline $\operatorname{CCF}(\$)$ & 32,861 & 11,949 & $(13,890)$ \\
\hline
\end{tabular}

\subsubsection{0-HEAD DAIRY FARM}

Table 3.3.2 provides the investment merit statistics for a herd of 500 dairy cows. As mentioned earlier, a positive NPV indicates a project is cost-effective. The positive NPV data found for the covered lagoon digester indicates that the project has investment merit, and that project implementation would add close to $\$ 90,000$ in net farm income during its life. Evaluation of the NPV data in Table 3.3.2 reveals that neither the complete mix nor the plug flow digester has investment merit, given the assumptions used. Graphical evaluation of the other investment merit statistics for the three treatment techniques in Figure 3.3.4 provides a SPP of about 6.5 years for the covered lagoon digester $\underline{v}$. more than 12 years for both the complete mix and plug flow digesters. With respect to the NPV to real discount rate sensitivity analysis, Figure 3.3.5 shows that in order for the covered lagoon digester not be cost-effective, the real discount rate must be more than 10.5 percent. A real discount rate of 4.0 percent for the complete mix digester and 1.5 percent for the plug flow digester would provide investment merit. The second sensitivity analysis, IRR to project life (Figure 3.3.6), shows that the covered lagoon digester requires an 11 year period to cross the established hurdle rate and recover investment costs. The time required to cross the established hurdle rate and recover investment costs for the complete mix and plug flow digesters is not within their project lifetimes.

\begin{tabular}{|l|l|l|l|}
\hline $\begin{array}{l}\text { TABLE } \\
\text { 3.3.2 }\end{array}$ & $\begin{array}{l}\text { Covered } \\
\text { Lagoon }\end{array}$ & $\begin{array}{l}\text { Complefe } \\
\text { Mix }\end{array}$ & $\begin{array}{l}\text { Plug } \\
\text { Flow }\end{array}$ \\
\hline NPV (\$) & $12,507$. & $(41,902)$ & $(42,104)$ \\
IRR (\%) & 10.8 & 4.0 & $(1.4)$ \\
SPP (years) & $6.4: \cdots:$ & 12.3 & 12.9 \\
CCF (\$) & 89,718 & 61,270 & 12,420 \\
\hline
\end{tabular}

\subsubsection{0-HEAD DAIRY FARM}

Table 3.3.3 provides the investment merit statistics for a herd of 1000 dairy cows. As 
mentioned earlier, a positive NPV indicates that a project is cost-effective. The positive NPV data found for the covered lagoon digester indicates that the project has investment merit, and that project implementation would add over $\$ 200,000$ in net farm income during its life. Evaluation of the NPV data in Table 3.3.3 reveals that neither the complete mix nor the plug flow digester has investment merit, given the assumptions used. Graphical evaluation of the other investment merit statistics for the three treatment techniques in Figure 3.3.7 provides a SPP of a little more than 5.5 years for the covered lagoon digester $\underline{v_{\text {. }}}$ more than 9 years for both the complete mix and plug flow digesters. With respect to the NPV to real discount rate sensitivity analysis, Figure 3.3.8 demonstrates that in order for the covered lagoon digester not to be cost-effective, the real discount rate must be more than 14 percent. A real discount rate of less than 6.5 percent provides investment merit for the complete mix digester. A real discount rate of less than 5 percent is required to provide investment merit for the plug flow digester. The sensitivity analysis of IRR to project life (Figure 3.3.9), demonstrates that the covered lagoon digester requires an 8 year period to cross the established hurdle rate and recover investment costs. Since neither the complete mix nor plug flow digester has a positive NPV, they do not cross the established hurdle rate during their project lifetimes.

\begin{tabular}{|c|c|c|c|}
\hline TABLE 3,3.3 & $\begin{array}{l}\text { Covered } \\
\text { Lagoon }\end{array}$ & $\begin{array}{l}\text { Complete } \\
\text { Mix }\end{array}$ & $\begin{array}{l}\text { Plug } \\
\text { Flow }\end{array}$ \\
\hline NPY:(\$) & 49,891 & $(29,63,8)$ & $(34 ; 697)$ \\
\hline $\operatorname{IRR}(\%)$ & 13.9 & 6.6 & 4.7 \\
\hline spp (years) & $5: 6$ & 98 & 94 \\
\hline $\operatorname{CCF}(\$)$ & 200,041 & 169,887 & 65,879 \\
\hline
\end{tabular}

\subsubsection{REGRESSION ANALYSES OF DAIRY FARM DIGESTERS WITH ELECTRICITY GENERATION AND HIGH MANURE COLLECTED}

After calculating the investment merit statistics, an additional step was required to accomplish the first stated objective: estimate digester cost and IRR as functions of herd size. This section presents the results of the simple linear regression models accomplishing this objective.
As shown in Table 3.3.4, the cost function for a covered lagoon digester indicates that all points lie on the function's regression line. The cost function correlation coefficient suggests a perfect positive linear correlation between herd size and digester construction cost. Both the constant and coefficient " $\mathrm{t}$ " statistics for the cost function exceed the required $t$ distribution number with 1 degree of freedom (df) at the 5 percent level of significance. This leads to the conclusion that they are both statistically significant at that level. The regression equation estimated for the cost function is graphically presented in Figure 3.3.10.

\begin{tabular}{|c|c|c|}
\hline $\begin{array}{l}\text { TABLE } \\
3.3 .4\end{array}$ & $\begin{array}{l}\text { Cost } \\
\text { Function }\end{array}$ & $\begin{array}{l}\text { IRR } \\
\text { Function }\end{array}$ \\
\hline $\mathbf{R}^{2} \because \ddots \cdots \cdots$ & $100 \cdot 0$ & 0,91 \\
\hline $\mathbf{r}$ & 1.00 & 0.95 \\
\hline oonstant $t$ & 370 & 2,36 \\
\hline Coefficient $t$ & 74.92 & 3.20 \\
\hline Estimating & $37500+126(x)$ & $4: 07+0.010(x)$ \\
\hline Equation & : & $\because: \cdots$ \\
\hline $\begin{array}{l}\text { Minimum } \\
\text { Herd Size }\end{array}$ & N/A & 395 to 564 \\
\hline
\end{tabular}

The IRR function for covered lagoon digesters indicates that the regression equation explains about 91 percent of the total variation in IRR. The remaining 9 percent is attributed to error term factors. The IRR function correlation coefficient is a near perfect positive linear correlation. However, neither the constant nor coefficient " $t$ " statistics for the IRR function exceeds the required $t$ distribution number with 1 degree of freedom (df) at the 5 percent level of significance; therefore, the variables are not statistically significant at that level. It is possible that a different functional form, such as a double log, would provide a better fit than the linear form. The regression equation that was estimated for the IRR function is graphically presented in Figure 3.3.11 and has a confidence level of one negative standard error incorporated. The IRR function was algebraically manipulated to provide the minimum herd size needed to operate a covered lagoon digester on a dairy farm with electricity generation and high manure collection. This was estimated to be between 395 and 564 cows at the established real discount rate of 8.5 percent. 
As shown in Table 3.3.5, the cost function for a complete mix digester indicates that all points lie on the function's regression line. The cost function correlation coefficient suggests a perfect positive linear correlation between herd size and the cost of constructing a digester. Since both the constant and coefficient " $t$ " statistics for the cost function exceed the required $t$ distribution number with 1 degree of freedom (df) at the 5 percent level of significance, they are both statistically significant at that level. The estimated regression equation for the cost function is graphically presented in Figure 3.3.12.

\begin{tabular}{|c|c|c|}
\hline $\begin{array}{l}\text { TABLE } \\
3.3 .5\end{array}$ & $\begin{array}{l}\text { Cost } \\
\text { Function }\end{array}$ & $\begin{array}{l}R R \\
\text { Function }\end{array}$ \\
\hline $\mathrm{R}^{2}$ & 1.00 & 0.96 \\
\hline $\mathbf{r}$ & 1.00 & 0.98 \\
\hline Constant $t$ & 26.96 & -0.06 \\
\hline Coefficient $t$ & 48.44 & 4.66 \\
\hline Estimating & $.70,600+192(x)$ & $=0.05+0.007(x)$ \\
\hline Equation & $\because$ & $\because$ \\
\hline $\begin{array}{l}\text { Minimum } \\
\text { Herd Size }\end{array}$ & N/A & 1,251 to 1,367 \\
\hline
\end{tabular}

The IRR function for a complete mix digester indicates that the regression equation explains about 96 percent of the total variation in IRR. The remaining 4 percent is attributed to error term factors. The IRR function correlation coefficient is a near perfect positive linear correlation. However, like the covered lagoon digester discussed earlier, neither the constant nor coefficient " $t$ " statistics for the IRR function exceed the required $t$ distribution number with 1 degree of freedom (df) at the 5 percent level of significance; therefore, the variables are not statistically significant at that level. It is possible that a different functional form would provide a better fit than the linear form. The regression equation that was estimated for the IRR function is graphically presented in Figure 3.3.13 and has a confidence level of one negative standard error incorporated. The IRR function was algebraically manipulated to provide the minimum herd size needed to operate a complete mix digester on a dairy farm with electricity generation and high manure collection. This was estimated to be between 1,251 and 1,367 cows at the established real discount rate of 8.5 percent.
As shown in Table 3.3.6, the cost function for a plug flow digester indicates that all points lie on the function's regression line. The correlation coefficient suggests a perfect linear correlation between herd size and the cost of constructing a digester. Since both the constant and coefficient " $t$ " statistics for the cost function exceed the required $t$ distribution number with 1 degree of freedom (df) at the 5 percent level of significance, they are both statistically significant at that level. The estimated cost function regression equation is graphically presented in Figure 3.3.14.

\begin{tabular}{|l|l|l|}
\hline TABLE & $\begin{array}{l}\text { Cost } \\
\text { Function }\end{array}$ & $\begin{array}{l}\text { IRR } \\
\text { Function }\end{array}$ \\
\hline 3.3.6 & 1.00 & 0.95 \\
$\mathbf{R}$ & 1.00 & .0 .97 \\
Constantt & 47.01 & -2.87 \\
Coefficient t & 56.45 & 4.27 \\
Estimationg & $67,700+123(x)$ & $-4.04+0.009(x)$ \\
Equation & & \\
Minimum & N/A & 1,378 to 1,505 \\
Herd Size & & \\
\hline
\end{tabular}

The IRR function for a plug flow digester indicates that the regression equation explains about 95 percent of the total variation in IRR. The remaining 5 percent is attributed to error term factors. The IRR function correlation coefficient is a near perfect positive linear correlation. However, neither the constant nor coefficient " $t$ " statistics for the IRR function exceeds the required $t$ distribution number with 1 degree of freedom (df) at the 5 percent level of significance; therefore, the variables are not statistically significant at that level. It is possible that a different functional form, such as a double log, would provide a better fit than the linear form. The regression equation that was estimated for the IRR function is graphically presented in Figure 3.3.15 and has a confidence level of one negative standard error incorporated. The IRR function was algebraically manipulated to provide the minimum herd size needed to operate a plug flow digester on a dairy farm with electricity generation and high manure collection. This was estimated to be between 1,378 and 1,505 cows at the established real discount rate of 8.5 percent. Because of USEPA's assumption that only 40 percent of the manure found on the feed apron was used, it is almost certain that the profitable application of plug flow 
digesters is several hundred cows less than the range estimated here.

\subsection{SWINE FARM DIGESTERS WITH ELECTRICITY GENERATION AND ALL MANURE COLLECTED}

This section evaluates the investment merit of two types of anaerobic digesters used on swine farms with herd sizes of 500, 1000 and 5000 hogs. Herd size refers to the number of on-farm animals having the average weight of 138 pounds per hog. It was assumed that all manure generated on the farm was collected. For the purpose of estimating biogas recovery rates, the covered lagoon digester was assumed to be located in Sampson County, North Carolina. The digester capital costing information represented the total "turn-key" cost of all materials, labor and engineering services required to bring a project on-line. The value of the digester was a function of how the energy was used, in other words, the direct energy costs avoided by the farmer. No credit was assumed for reducing environmental externalities. The assumed value of each digester was established by the amount of electricity generated and heat reclaimed from the engine/generator. The electricity was used on-farm as an offset for currently-purchased power utilized for fan and pump motors, and other equipment. In determining the avoided cost of purchased power, the electricity rate used was representative of rates in Sampson County, North Carolina. Annual operating and maintenance costs were used as provided.

\subsubsection{0-HEAD SWINE FARM}

Table 3.4.1 provides the investment merit statistics for a herd of 500 swine. As mentioned earlier, a positive NPV indicates that a project is cost-effective. The NPV data indicates that neither the covered lagoon nor the complete mix digester has investment merit, given the assumptions used. Graphic evaluation of the other investment merit statistics for the two treatment techniques provides a SPP of about 10 years for the covered lagoon digester $\underline{v}$. more than 16 years for the complete mix digester (Figure 3.4.1). There were two sensitivity analyses performed on the two treatment choices. The first determines NPV to real discount rate, which will find if there is a positive discount rate yielding a positive NPV. Figure 3.4 .2 indicates that the real discount rate must be less than 4.5 percent in order for the covered lagoon digester to have investment merit and less than 2 percent for the complete mix digester. The second sensitivity analysis determined IRR to project life. This figure reveals the time period required to recover investment when crossing the established hurdle rate in "discounted" dollars, and can be thought of as providing a project's discounted (and therefore true) payback period (DPP). As shown in Figure 3.4.3, because the NPV for both digesters is negative, neither crosses the established hurdle rate during its project lifetime.

\begin{tabular}{|c|c|c|}
\hline TABLE 3.4.1 & Covered Lagoon & Complete MIX \\
\hline MPY(S) & $(10,288)$ & $(31,036)$ \\
\hline $\operatorname{IRR}(\%)$ & 4.1 & 1.6 \\
\hline sppofyears) & 99 :4 & 16.3 \\
\hline CCF $(\$)$ & 14,550 & 11,326 \\
\hline
\end{tabular}

\subsubsection{0-HEAD SWME FARM}

Table 3.4 .2 provides the investment merit statistics for a herd of 1000 swine. As mentioned earlier, a positive NPV indicates that a project is cost-effective. The NPV data indicates that neither the covered lagoon nor the complete mix digester has investment merit, given the assumptions used. Graphic evaluation of the other investment merit statistics for the two digesters provides a SPP of about 7.5 years for the covered lagoon digester $\underline{v}$. about 10.5 years for the complete mix digester (Figure 3.4.4). The first sensitivity analysis performed, NPV to real discount rate (Figure 3.4.5), reveals that to have investment merit the real discount rate must be less than 8 percent for the covered lagoon digester and less than 5.5 percent for the complete mix digester. The second sensitivity analysis, IRR to project life (Figure 3.4.6), demonstrates that because the NPV for both digesters is negative, neither crosses the established hurdle rate during its project lifetime.

\begin{tabular}{|c|c|c|}
\hline TABLE 3.4.2 & Covered Lagoon & Complete Mix \\
\hline NPY:(S): & $(2 ; 088) \quad 1$ & $(20,038)$ \\
\hline IRR (\%) & & 5.4 \\
\hline $\begin{array}{l}\text { SPP (years) } \\
\operatorname{CCF}(\$)\end{array}$ & $\begin{array}{l}7: 4, \\
44,659\end{array}$ & $\begin{array}{l}10.6 \\
57,452\end{array}$ \\
\hline
\end{tabular}




\subsubsection{0-HEAD SWINE FARM}

Table 3.4 .3 provides the investment merit statistics for a herd of 5000 swine. The positive NPV found for both the covered lagoon and complete mix digesters indicates that the two technologies have investment merit. Implementation of the covered lagoon project would add over $\$ 288,000$ in net farm income during its life, and the complete mix project would add over $\$ 446,000$ during its life. Graphic evaluation of the other investment merit statistics for the two techniques provides a SPP of about 6 years for both digesters (Figure 3.4.7). With respect to the NPV to real discount rate sensitivity analysis, Figure 3.4.8 illustrates that in order for the two digesters not to have investment merit, the real discount rate must be more than 13.5 percent. The second sensitivity analysis, IRR to project life (Figure 3.4.9), reveals that about a 9 year time period is required to recover investment costs for the two treatment technologies.

\begin{tabular}{|c|c|c|}
\hline TABLE 3.4.3 & Covered Lagoon & Complete Mix \\
\hline NPV $(\$)$ & 66,970 & 89,053 \\
\hline IRR (\%) & 13.3 & 13.1 \\
\hline SPP (years) & 5.8 & 6.1 \\
\hline $\operatorname{CCF}(\$)$ & 288,835 & 446,056 \\
\hline
\end{tabular}

\subsubsection{REGRESSION ANALYSES OF SWNE FARM DIGESTERS WTH ELECTRICITY GENERATION AND ALL MANURE COLLECTED}

After calculating the investment merit statistics earlier, an additional step was required to estimate digester cost and IRR as functions of herd size. This section presents the results of the two simple linear regression models that accomplish this objective.

As shown in Table 3.4.4, the covered lagoon digester cost function indicates that all points lie on the function's regression line. Its correlation coefficient suggests a perfect positive linear correlation between herd size and digester construction cost. Both the constant and coefficient " $\mathrm{t}$ " statistics for the cost function exceed the required $t$ distribution number with 1 degree of freedom (df) at the 5 percent level of significance, leading to the conclusion that they are both statistically significant at that level. The estimated regression equation for the cost function is graphically presented in Figure 3.4.10.

\begin{tabular}{|l|l|l|}
\hline TABLE & Cost & IRR \\
3.4 .4 & Function & Function \\
\hline $\mathrm{R}^{2} \quad::$ & 1.00 & 0.90 \\
$\mathrm{r}$ & 1.00 & 0.95 \\
Constant $t$ & $85: 08$ & 2.64 \\
Coefficient $t$ & 417.27 & 2.97 \\
Estimating & $26.87 .1+45(x)$ & $4.63+0.002(x)$ \\
Equation & & \\
Minimum & N/A & 2,193 to 3,366 \\
Herd Size & & \\
\hline
\end{tabular}

The IRR function for a covered lagoon digester indicates that the regression equation explains about 90 percent of the total variation in IRR. The remaining 10 percent is attribụted to error term factors. The IRR function correlation coefficient is a near perfect positive linear correlation. However, neither the constant nor coefficient " $t$ " statistics for the IRR function exceeds the required $t$ distribution number with 1 degree of freedom (df) at the 5 percent level of significance; therefore, the variables are not statistically significant at that level. It is possible that a different functional form, such as a double log, would provide a better fit than the linear form. The regression equation that was estimated for the IRR function is graphically presented in Figure 3.4.11 and has a confidence level of one negative standard error incorporated. The IRR function was algebraically manipulated to provide the minimum herd size needed to operate a covered lagoon digester on a swine farm with electricity generation and all manure collected. This was estimated to be between 2,193 and 3,366 swine at the established real discount rate of 8.5 percent.

As shown in Table 3.4.5, the cost function for a complete mix digester indicates that all points lie on the function's regression line. The cost function correlation coefficient suggests a perfect positive linear correlation between herd size and the cost of constructing a digester. Since both the constant and coefficient " $t$ " statistics for the cost function exceed the required $t$ distribution number with 1 degree of freedom (df) at the 5 percent level of significance, they are both statistically significant at that level. The estimated 
regression equation for the cost function is graphically presented in Figure 3.4.12.

\begin{tabular}{|c|c|c|}
\hline $\begin{array}{l}\text { TABLE } \\
3.4 .5\end{array}$ & $\begin{array}{l}\text { Cost } \\
\text { Function }\end{array}$ & $\begin{array}{l}\text { IRR } \\
\text { Function }\end{array}$ \\
\hline $\mathrm{R}^{2} \quad \mathrm{l} / \mathrm{l}$ & $100 \%, 6$ & $095 \quad+1$ \\
\hline$r$ & 1.00 & 0.97 \\
\hline Constant $t$ & $33.41 \% \%$ & 104 \\
\hline Coefficient $t$ & 65.59 & 4.31 \\
\hline Estimatong & $64726+46(x)$ & $1.65+0.002(x)$ \\
\hline Equation & $\%$ & el \\
\hline $\begin{array}{l}\text { Minimum } \\
\text { Herd Size }\end{array}$ & NIA & 2,948 to 3,757 \\
\hline
\end{tabular}

The IRR function for a complete mix digester indicates that the regression equation explains about 95 percent of the total variation in IRR. The remaining 5 percent is attributed to error term factors. The IRR function correlation coefficient is a near perfect positive linear correlation. However, neither the constant nor coefficient " $t$ " statistics for the IRR function exceeds the required $t$ distribution number with 1 degree of freedom (df) at the 5 percent level of significance; therefore, the variables are not statistically significant at that level. It is possible that a different functional form, such as a double log, would provide a better fit than the linear form. The regression equation that was estimated for the IRR function is graphically presented in Figure 3.4.13 and has a confidence level of one negative standard error incorporated. The IRR function was algebraically manipulated to provide the minimum herd size needed to operate a complete mix digester on a swine farm with electricity generation and all manure collected. This was estimated to be between 2,948 and 3,757 swine at the established real discount rate of 8.5 percent.

\subsection{ILLUSTRATION OF CO- PRODUCT UTILIZATION}

The second objective of this section is to illustrate the importance of maximizing coproduct utilization and other offsets made available by adopting anaerobic digestion technology. As in the earlier evaluations, the types of digesters analyzed were covered lagoon, plug flow, and complete mix. Each digester type was evaluated under two specific scenarios. The first scenario accounted for a full revenue stream, which includes savings from on-farm electricity and heat recovery offsets, surplus electricity sales, manure disposal savings, and the sale of digested solids. The second scenario evaluated each digester technology accounting only for savings from on-farm electricity offsets and surplus electricity sales. As noted earlier, basic system data and additional macro variables were linked into CashFlow, a model that provides a summary of primary investment merit statistics.

\subsubsection{0-HEAD CALIFORNIA DAIRY FARM WITH COVERED LAGOON DIGESTER}

The manure was collected for this digester by a periodic scraping of the apron and feedlane and by the daily flushing of the milking parlor with water. It was assumed that the manure removed from the parlor and feedlane accounted for about 55 percent of the manure produced on the farm. The digested solids and liquids were assumed to have no monetary value, even though the liquids can be land applied with irrigation guns. The value of the 1000-head California covered lagoon digester was derived from the measure of offsets in currently-purchased electricity and from the recovery of heat from the engine/generator that was used to warm dairy sanitary wash water. The digester was assumed to have an average production capacity of $81-\mathrm{kW}$ and to have annually produced $504,111 \mathrm{kWh}$. Purchased electricity costs had a demand charge of about $\$ 5.00$ per $\mathrm{kW}$, with an energy charge of $\$ 0.050$ per $\mathrm{kWh}$. Available waste heat was used as an offset for purchased propane costing $\$ 0.75$ per gallon, with 2,800 Btu recovered for every $\mathrm{kWh}$ generated.

Table 3.5.1 provides the investment merit statistics for this project. As mentioned earlier, a positive NPV indicates that a project is costeffective. Evaluation of the NPV data in Table 3.5.1 reveals that a covered lagoon digester has investment merit when both electricity and recovered heat can be used as creditable offsets in the analysis. But if, for example, the waste heat recovered from the engine/generator were to be used for heating the digester during the winter in cooler climates to balance daily biogas production, the covered lagoon digester would be no longer costeffective. 


\begin{tabular}{|c|c|c|}
\hline TABLE 3.5.1 & Full Income & $\begin{array}{l}\text { Electricity } \\
\text { Only }\end{array}$ \\
\hline NPV(\$) & 36,075 & $(23,476)$ \\
\hline IRR (\%) & & 6.2 \\
\hline SPP (years) & 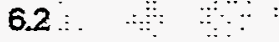 & $\because$ \\
\hline CCF (\$) & 200,987 & 93,419 \\
\hline
\end{tabular}

\subsubsection{0-HEAD SOUTH DAKOTA DAIRY FARM WTH PLUG FLOW DIGESTER}

The manure was collected for this digester by a daily scraping of the apron and feedlane. It was assumed that 100 percent of the manure was collected and placed into the digester after it was diluted with a sufficient volume of water to produce the desired solids loading rate. The value of the 300-head South Dakota plug flow digester was derived, in part, from a change in manure management. It was assumed that the facility formerly used a hauling company to remove the manure from the farm at an annual cost of $\$ 2$ per cow. This assumption means that the expenses associated with manure disposal were converted into revenue for the farm operator. It was also assumed that the digested solids were used as a soil amendment with a value of $\$ 2000$ annually. The farm received offsets in currently-purchased electricity and from the recovery of heat from the engine/generator that is used to warm dairy sanitary wash water. The digester was assumed to have an average production capacity of $35-\mathrm{kW}$, and annually produced $216,047 \mathrm{kWh}$. Purchased electricity costs had an energy-only charge of $\$ 0.075$ per $\mathrm{kWh}$. The digester produced more electricity than was consumed on the farm, and the surplus was sold at $\$ 0.05$ per $\mathrm{kWh}$. Available waste heat was used as an offset for purchased propane costing $\$ 0.75$ per gallon, with 2,800 Btu recovered for every $\mathrm{kWh}$ generated.

Table 3.5.2 provides the investment merit statistics for this example. As mentioned earlier, a positive NPV indicates that a project is cost-effective. Evaluation of the NPV data in Table 3.5.2 reveals that a plug flow digester has investment merit when all of the energy and recoverable co-products can be used as creditable offsets in the analysis. But if, for example, the manure disposal savings and digested solids recovered were not creditable, and the waste heat from the engine/generator was not recovered and was instead used to heat the digester during the winter, the plug flow digester is no longer cost-effective.

\begin{tabular}{|c|c|c|}
\hline TABLE 3.5.2 & Full Income & $\begin{array}{l}\text { Electricity } \\
\text { Onty }\end{array}$ \\
\hline NPV (\$) & 88,124 & $(44,646)$ \\
\hline IRR (\%) & 10.8 & 1.7 \\
\hline SpP. (years) & $6: 4:$ & 12.5 \\
\hline $\operatorname{CCF}(\$)$ & 130,331 & 16,949 \\
\hline
\end{tabular}

\subsubsection{0,000-HEAD NEBRASKA SWINE FARM WITH COMPLETE MIX DIGESTER}

It was assumed the complete mix digester was located on a farrow-to-finish farm using underfloor scrapers to move the manure from the production parlors to a holding pit. It was also assumed that 100 percent of the manure was collected and placed into the digester. The value of the 10,000-head Nebraska complete mix digester was derived from the measure of offsets that the farm received from currently-purchased electricity and from recovery of heat from the engine/generator used for parlor heating. The digester had an average production capacity of $101-\mathrm{kW}$, and annually produced $624,137 \mathrm{kWh}$. Purchased electricity costs had an energy-only charge of $\$ 0.067$ per $\mathrm{kWh}$. The digester produced more electricity than was consumed on the farm, and the surplus was sold at an avoided cost of $\$ 0.04$ per $\mathrm{kWh}$. Available waste heat was used as an offset for purchased propane costing $\$ 0.75$ per gallon, with 2,800 Btu recovered for every $k W h$ generated.

Table 3.5.3 provides the investment merit statistics for this example. As mentioned earlier, a positive NPV indicates that a project is cost-effective. Evaluation of the NPV data in Table 3.5.3 reveals that a complete mix has investment merit when all of the energy and recoverable co-products can be used as creditable offsets in the analysis. But if, for example, the heat was recovered from the engine/generator were to be used for heating the digester during the winter in cooler climates, the complete mix digester would be no longer cost-effective. 


\begin{tabular}{|c|c|c|}
\hline TABLE 3.5.3 & Full Income & $\begin{array}{l}\text { Electricity } \\
\text { Only }\end{array}$ \\
\hline NPV(S) & 4446 & $(29,297)$ \\
\hline IRR (\%) & $8: 8$ & 6.5 \\
\hline Spp years) & $7 \%$ & 94 \\
\hline $\operatorname{CCF}(\$)$ & 228,659 & 157,979 \\
\hline
\end{tabular}

\subsection{SUMMARY OF ECONOMIC EVALUATIONS}

In this section, a guide was constructed to assess the economic benefit of anaerobic digesters. Three varieties of anaerobic digesters--covered lagoon, complete mix, and plug flow--were comparatively evaluated using three investment merit statistics--net present value, internal rate of return, and simple payback period. Life-cycle savings were estimated for the three types of digesters, with sensitivities considered for investment risk. A word of caution is in order. Most of the evaluations presented here should only be used to provide a rough estimation. Also, costeffective applications can be found with smaller herd sizes in areas that have higher energy rates than those assumed by USEPA.

Nevertheless, this section offers the following conclusions. First, a covered lagoon digester can have a relative economic advantage over both the complete mix and plug flow digesters because of lower capital cost and reduced operation and maintenance expenses. This advantage is limited by the warm geographic range necessary to operate a covered lagoon digester cost-effectively.

Second, having a full range of creditable coproducts that can be used as revenues in a pro forma analysis can make a significant difference in whether a project has investment merit for the user. Quite simply, it is very difficult to justify the investment in an anaerobic digester based only on the revenue received for offsetting currently-purchased electricity and the sales of surplus electricity. The profitable operation is one that maximizes utilization of both digested liquids and solids.

Finally, economics is a science which is too often criticized for "knowing the price of everything and the value of nothing". The analyses presented here do not provide a quantifiable price impact for some of the more subjective value advantages that can result from the adoption of farm-based anaerobic digestion technology.

For example, no value is calculated for environmental externalities. Unrecovered methane in biogas produced by the inevitable decomposition of animal manures is a suspected agent of global climate change. Conversion of biogas into less odious carbon dioxide can be accomplished through combustion by an engine/generator. A second unquantified externality is the ability of anaerobic digesters to help control odor and flies. With urban encroachment into rural areas, many farms today use a digester specifically installed for the purpose of odor control.

Other on-farm impacts are difficult to value. The installation of an anaerobic digester often reduces the direct labor requirements associated with daily manure management and especially the sometimes frequent need for holding pit pump-outs. Additional value can also be derived from reduction in the need to purchase fertilizers and soil conditioners. Just as many farmers do not charge for the value of their labor, many farmers also do not fully offset the cost reductions associated with using digested liquid nutrients or tilth-building solids. 
FIGURE 3.21: Comparative Cumulative Cash Flow for 250-Head Dairy Farm Digesters with Electricity Generation and Low Manure Collected

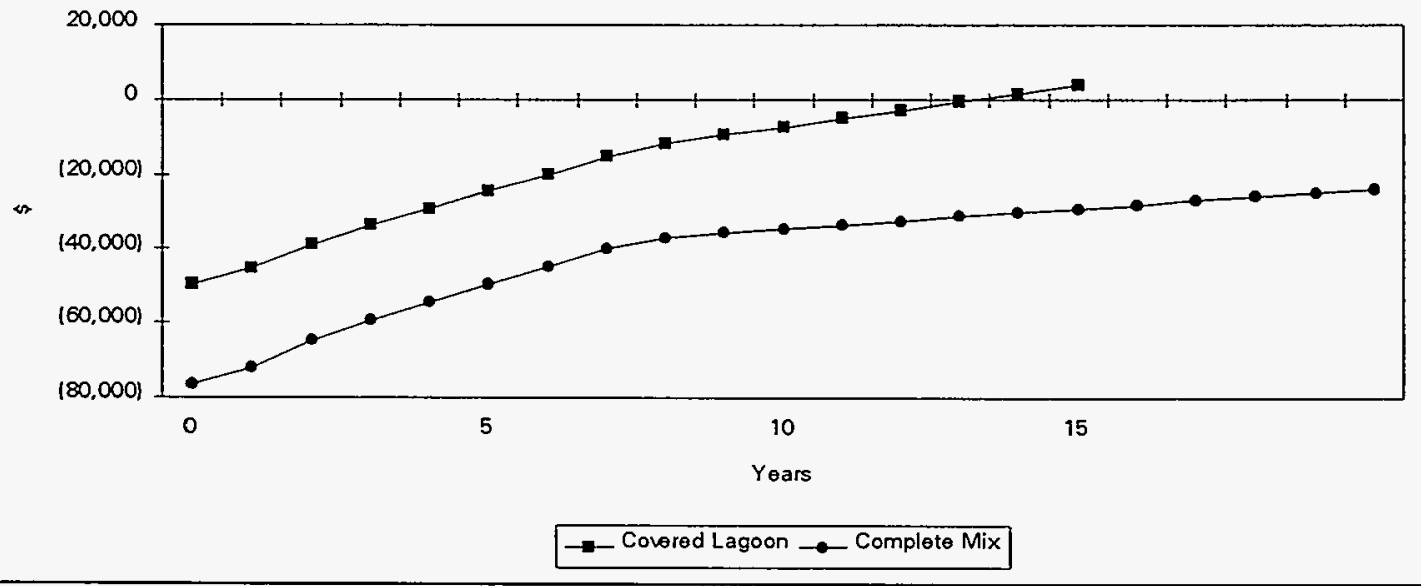

FIGURE 3.22: Comparative Net Present Value Sensitivity to Real Discount Rate for 250Head Dairy Farm Digesters with Electricity Generation and Low Manure Collected

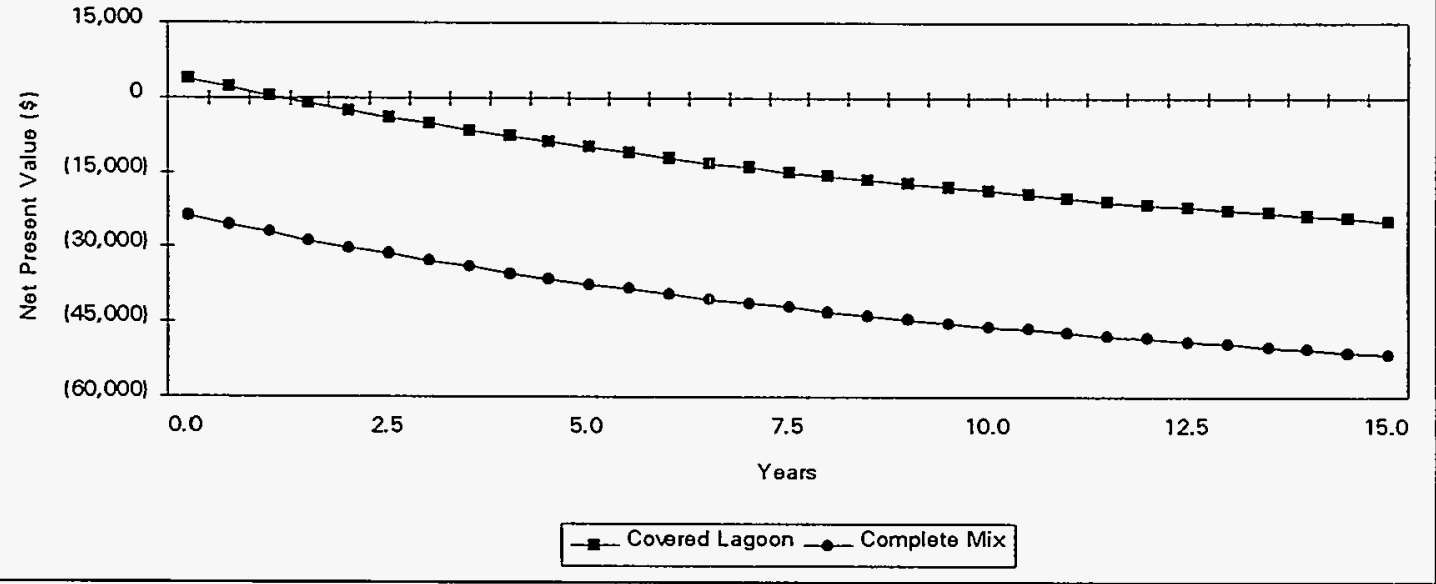

FIGURE 3.23: Comparative Internal Rate of Return Sensitivity to Project Life for 250Head Dairy Farm Digesters with Electricity Generation and Low Manure Collected

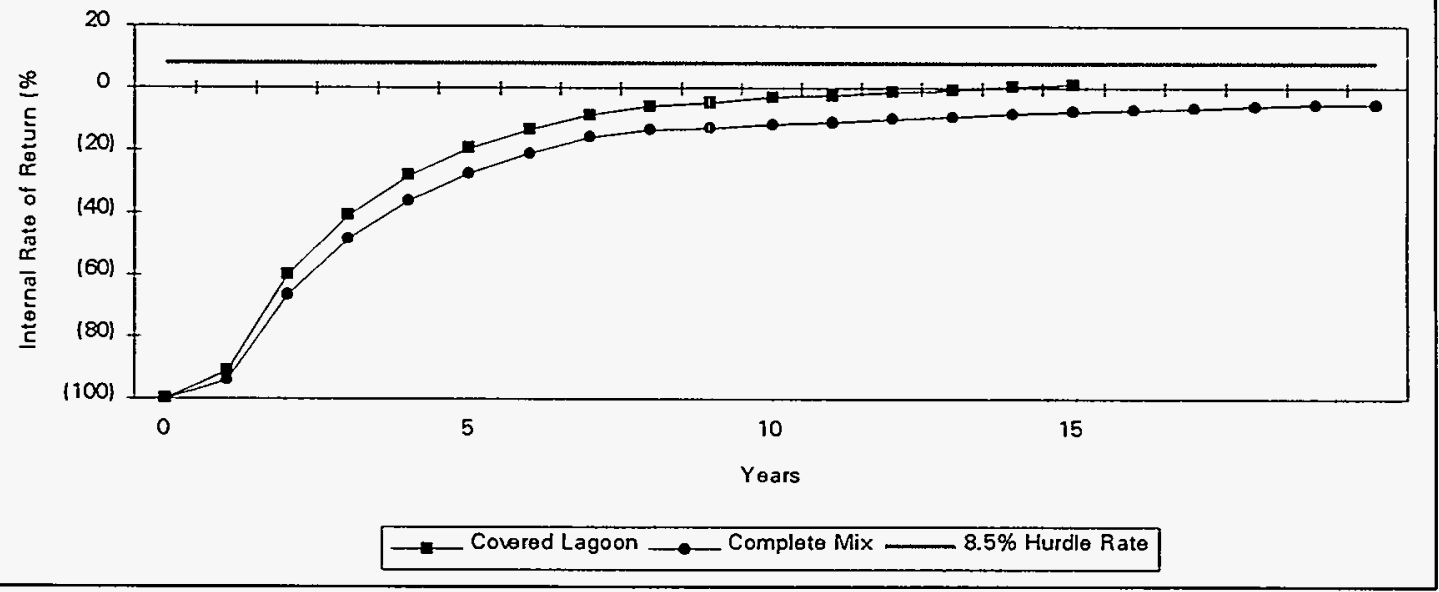


FIGURE 3.24: Comparative Cumulative Cash Flow for 500-Head Dairy Farm Digesters with Electricity Generation and Low Manure Collection
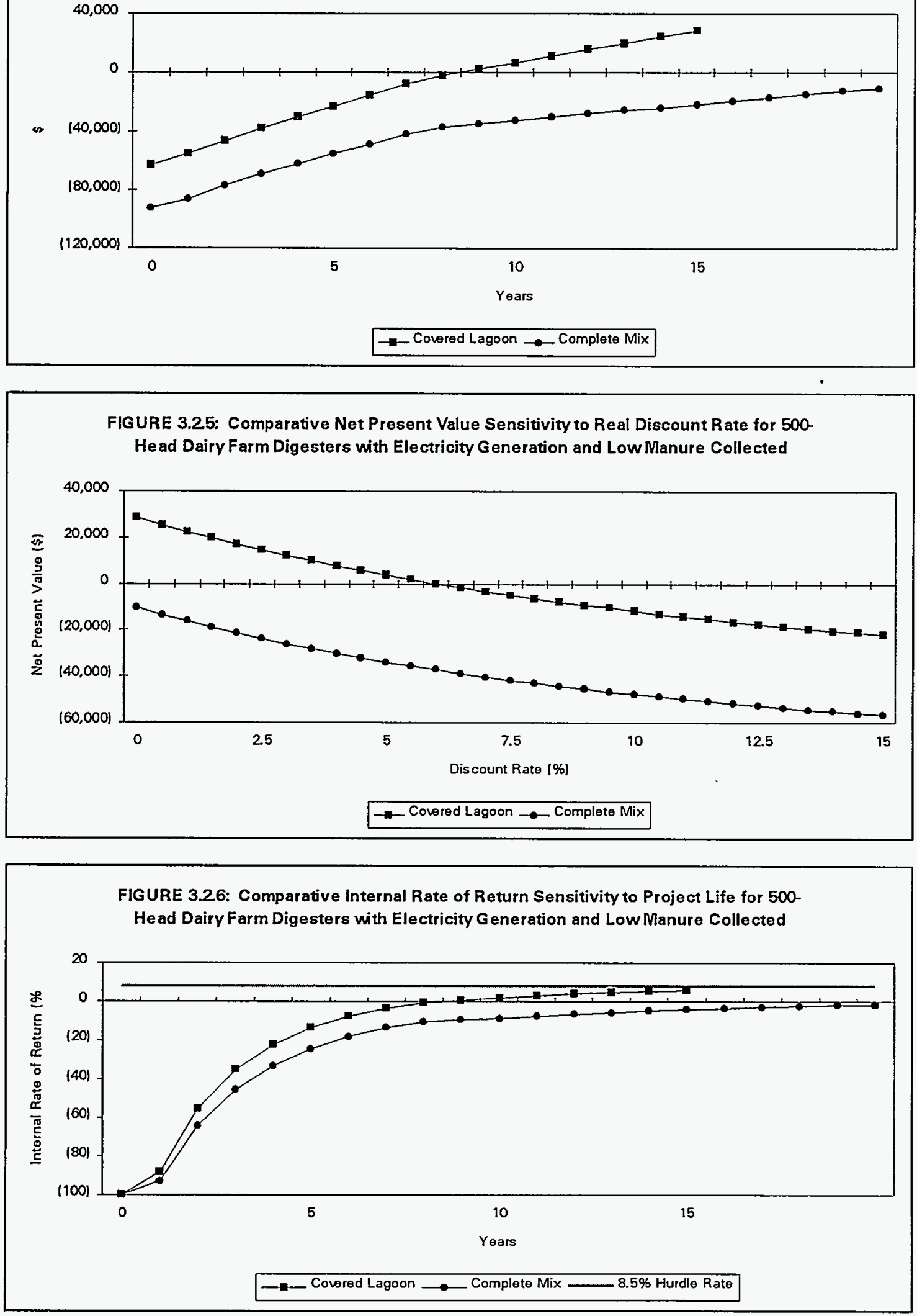

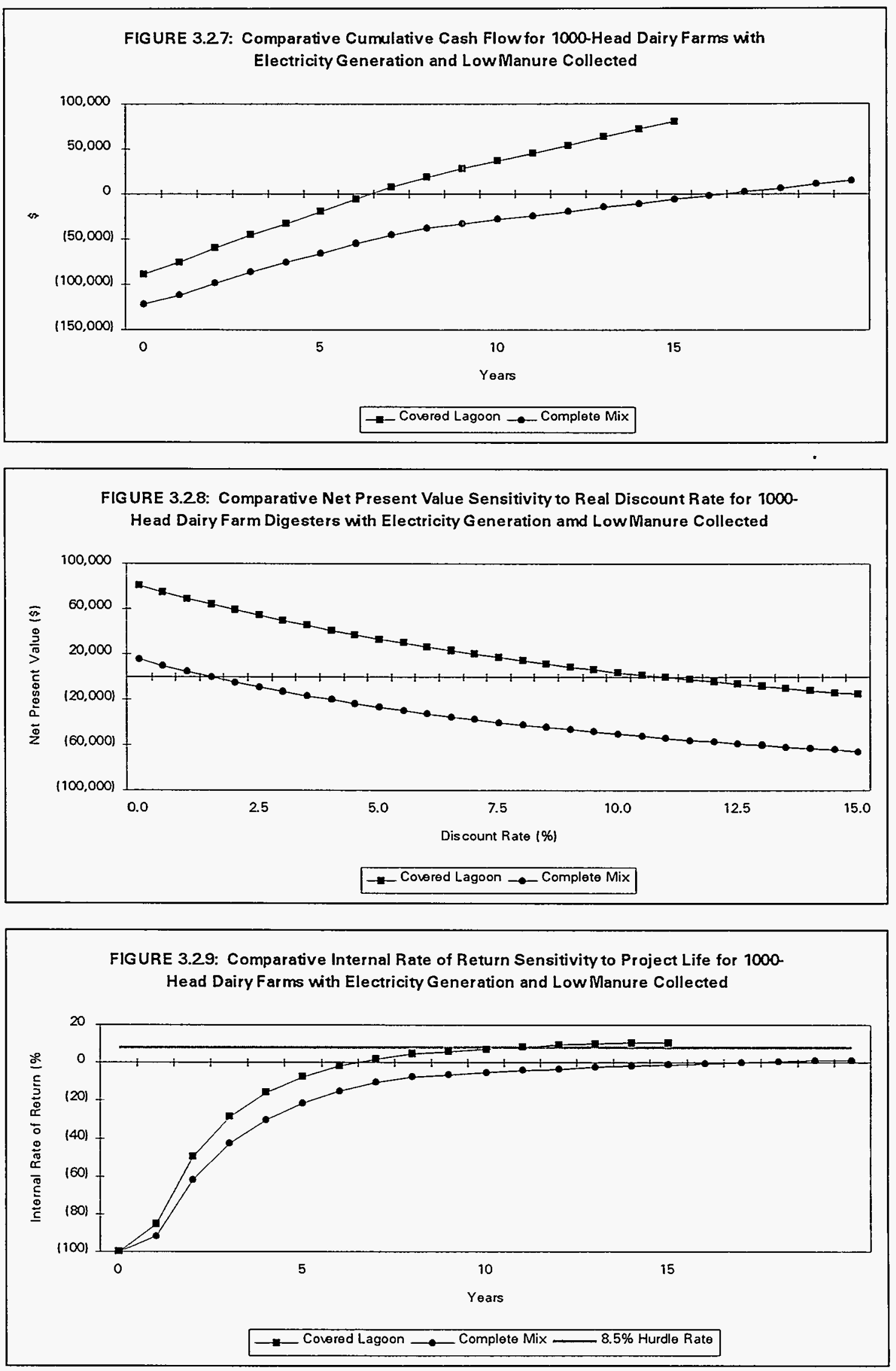

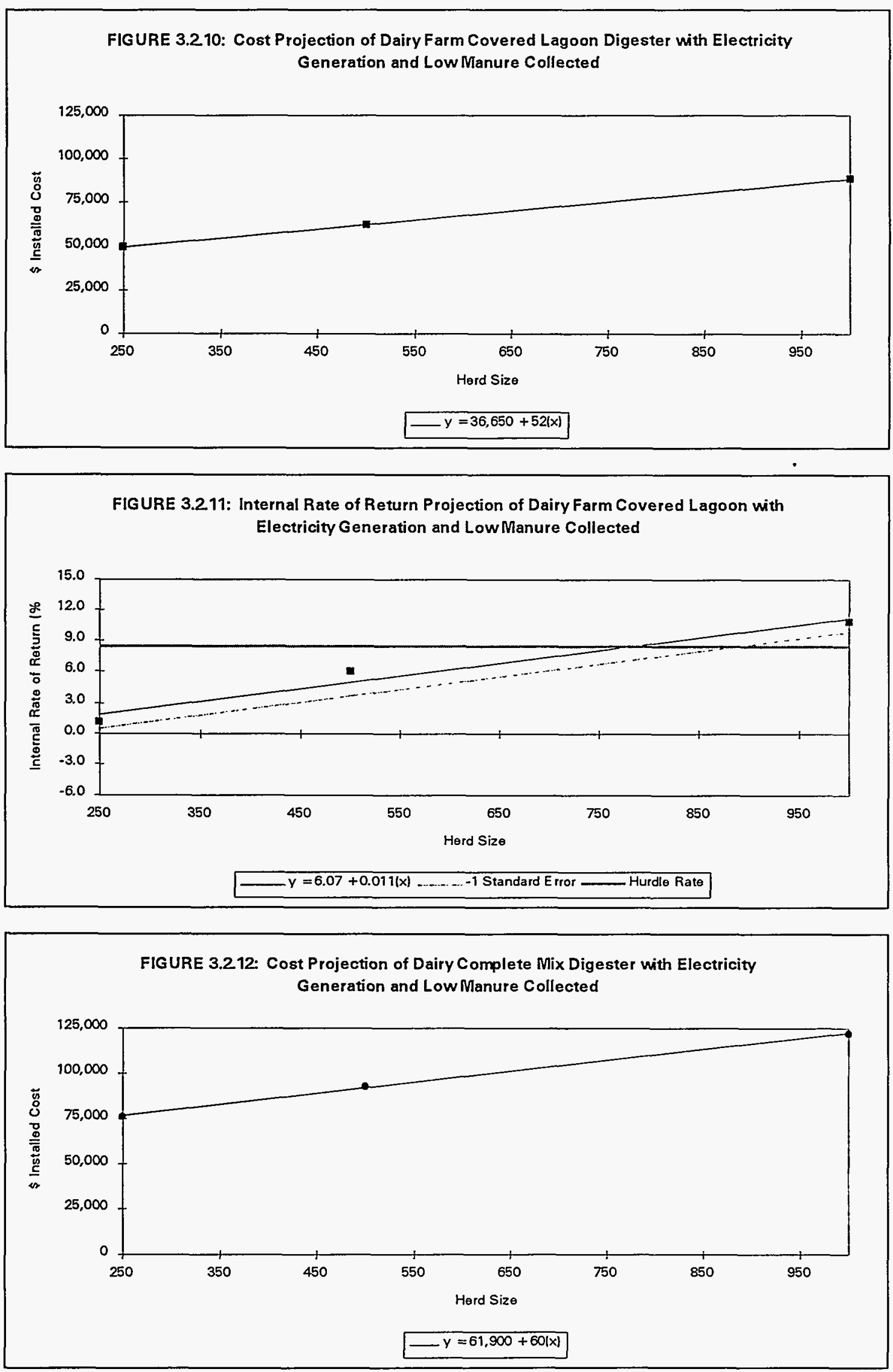

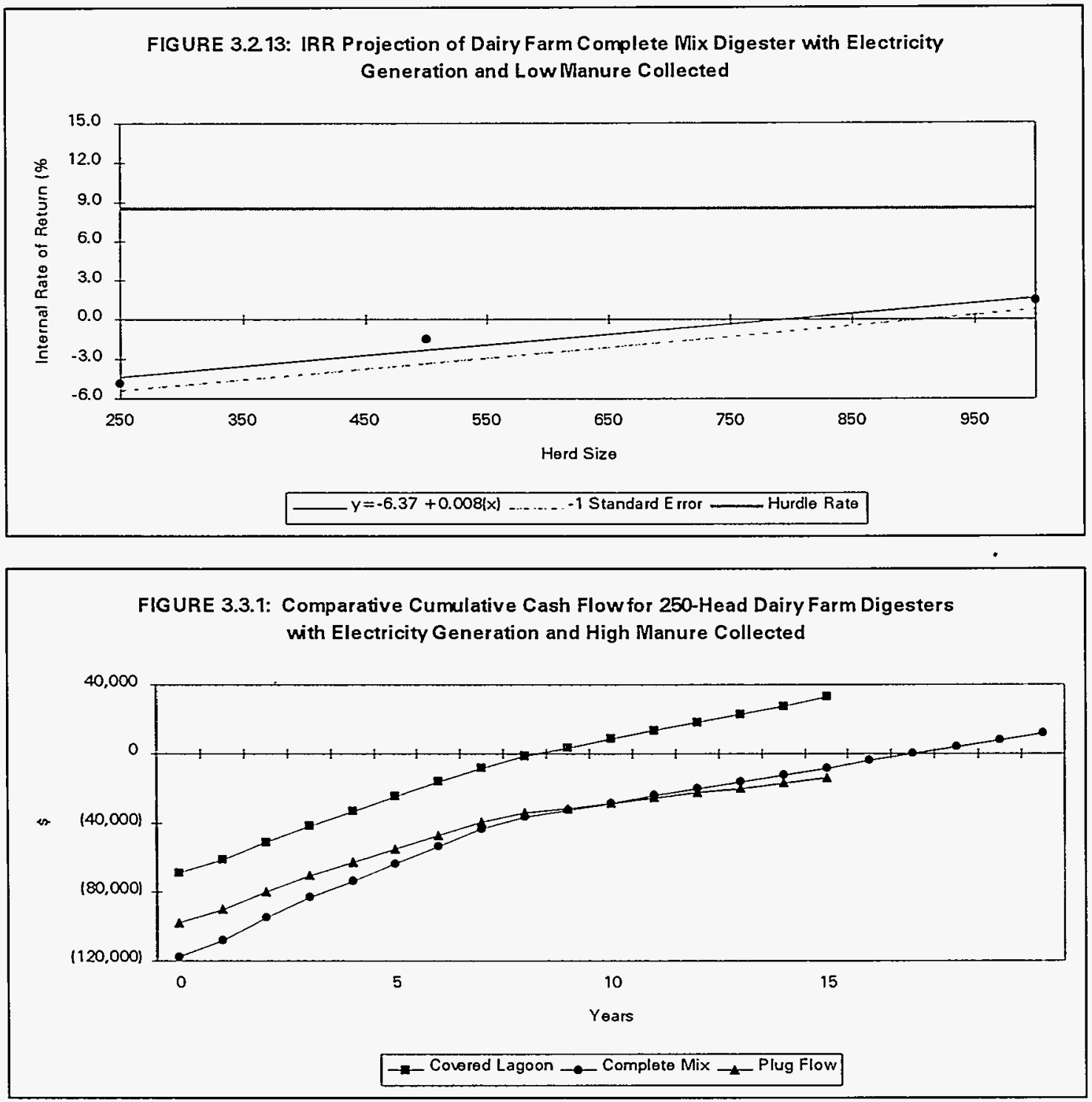

FIGURE 3.3.2 Comparative Net Present Value Sensitivity to Real Discount Rate for 250Head Dairy Farm Digesters with Electricity Generation and High Manure Collected

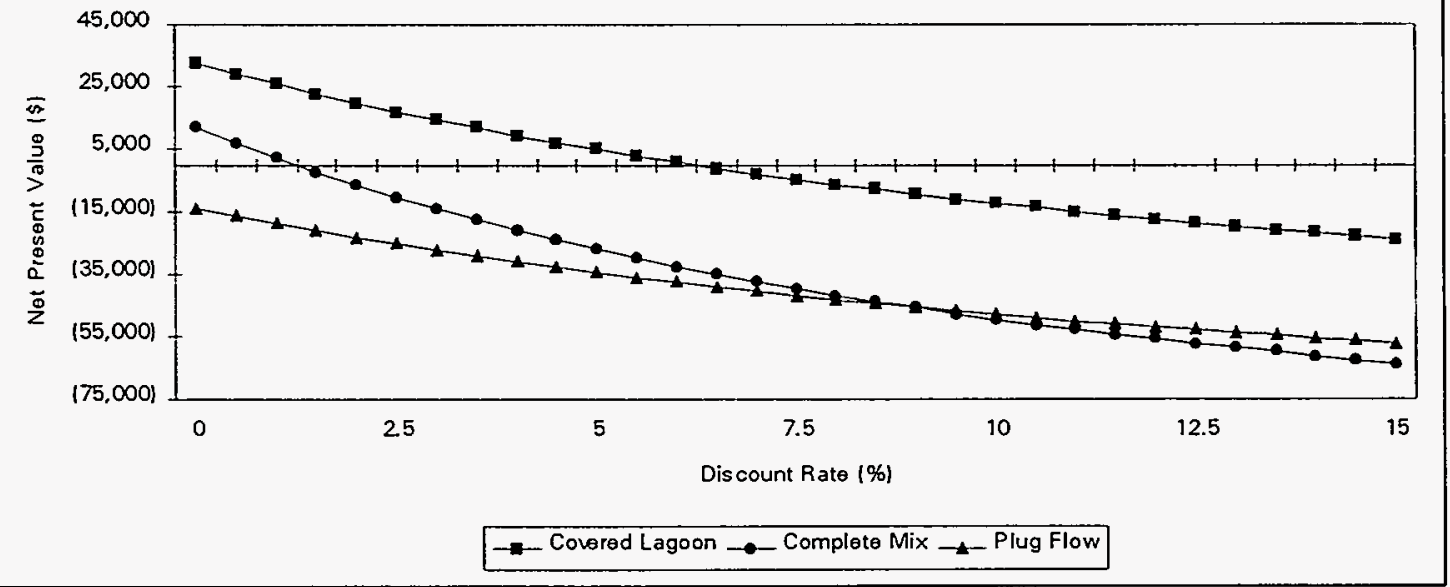


FIGURE 3.3.3: Comparative Internal Rate of Return Sensitivity to Project Life for 500Head Dairy Farm Digesters with Electricity Generation and Low Manure Collected

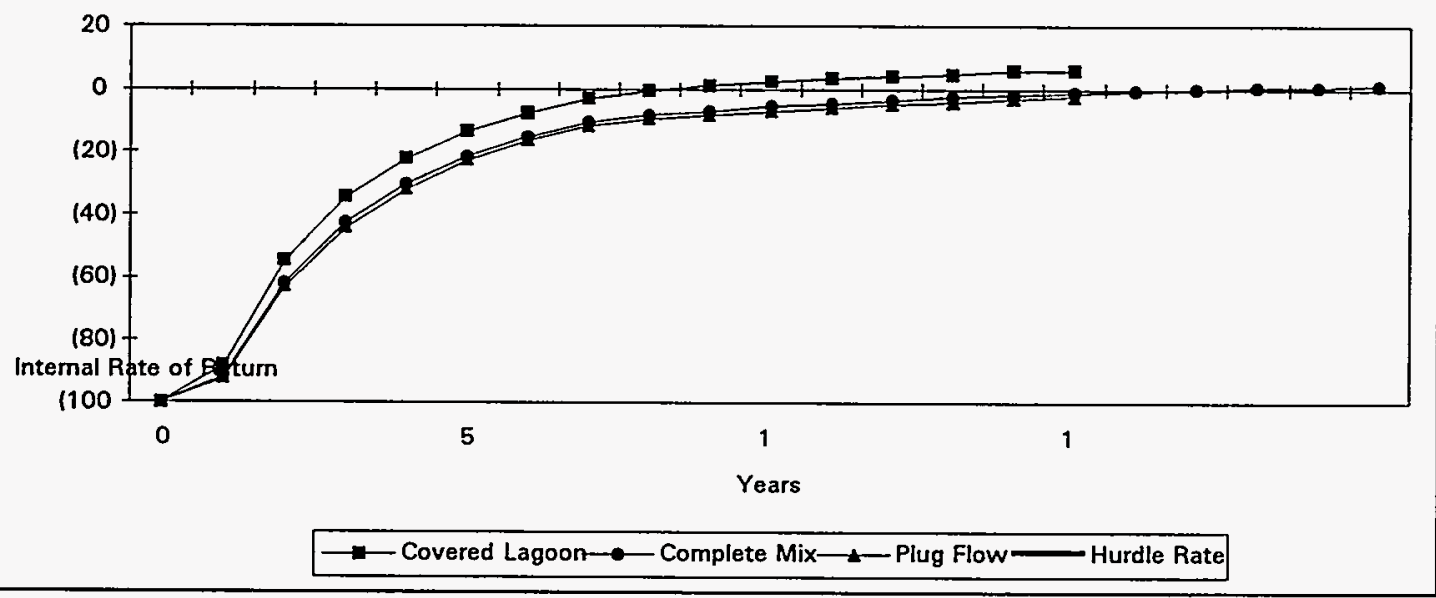

FIGURE 3.3.4: Comparative Cumulative Cash Flow for 500-Head Dairy Farm Digesters with Electricity Generation and High Manure Collected

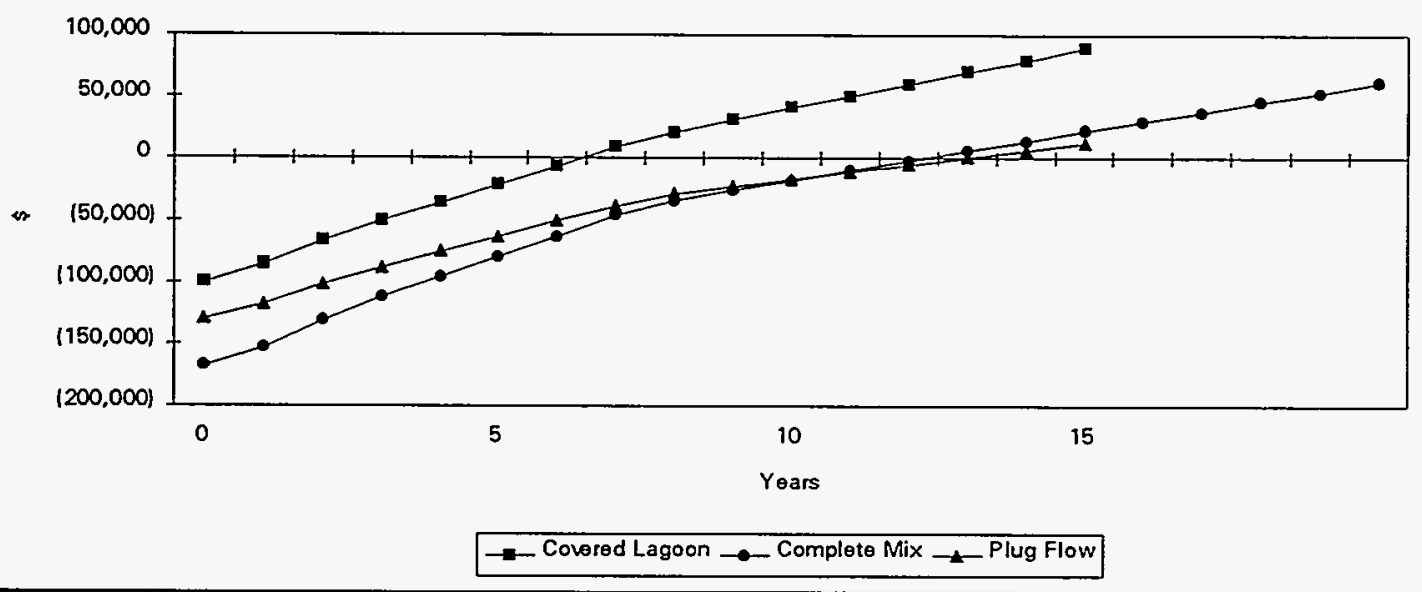

FIGURE 3.3.5: Comparative Net Present Value Sensitivity to Real Discount Rate for $500-$ Head Dairy Farms with Electricity Generation and High Manure Collected

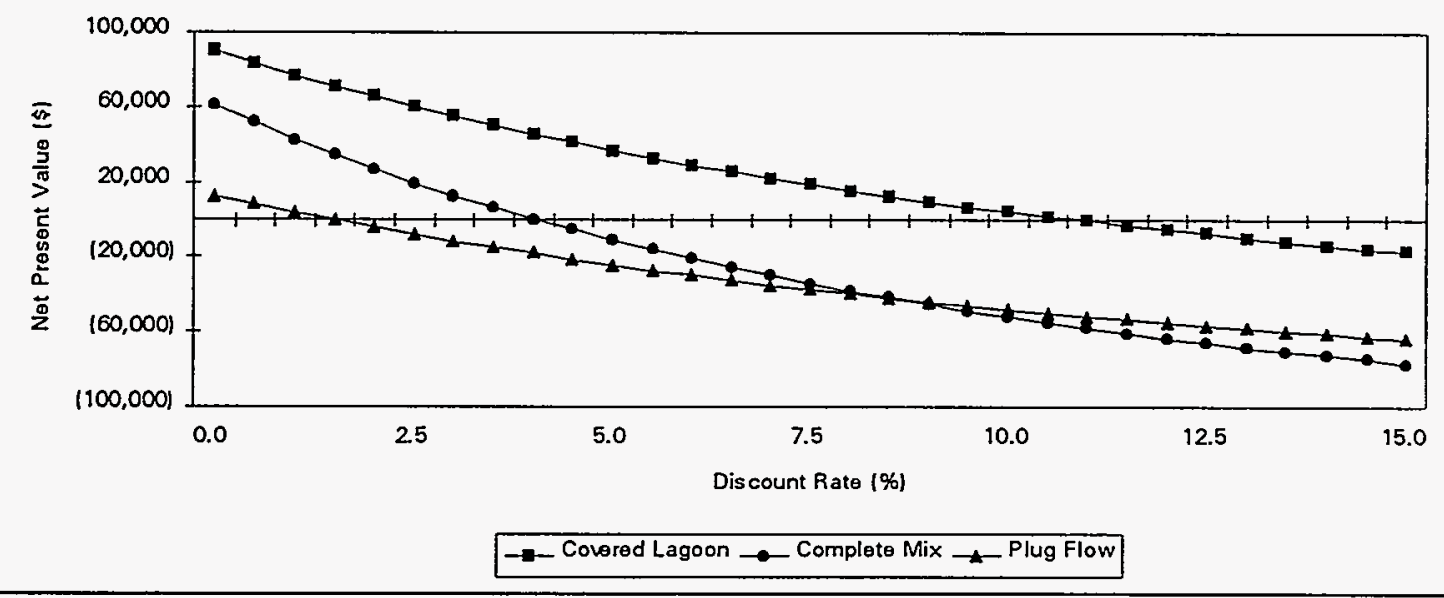




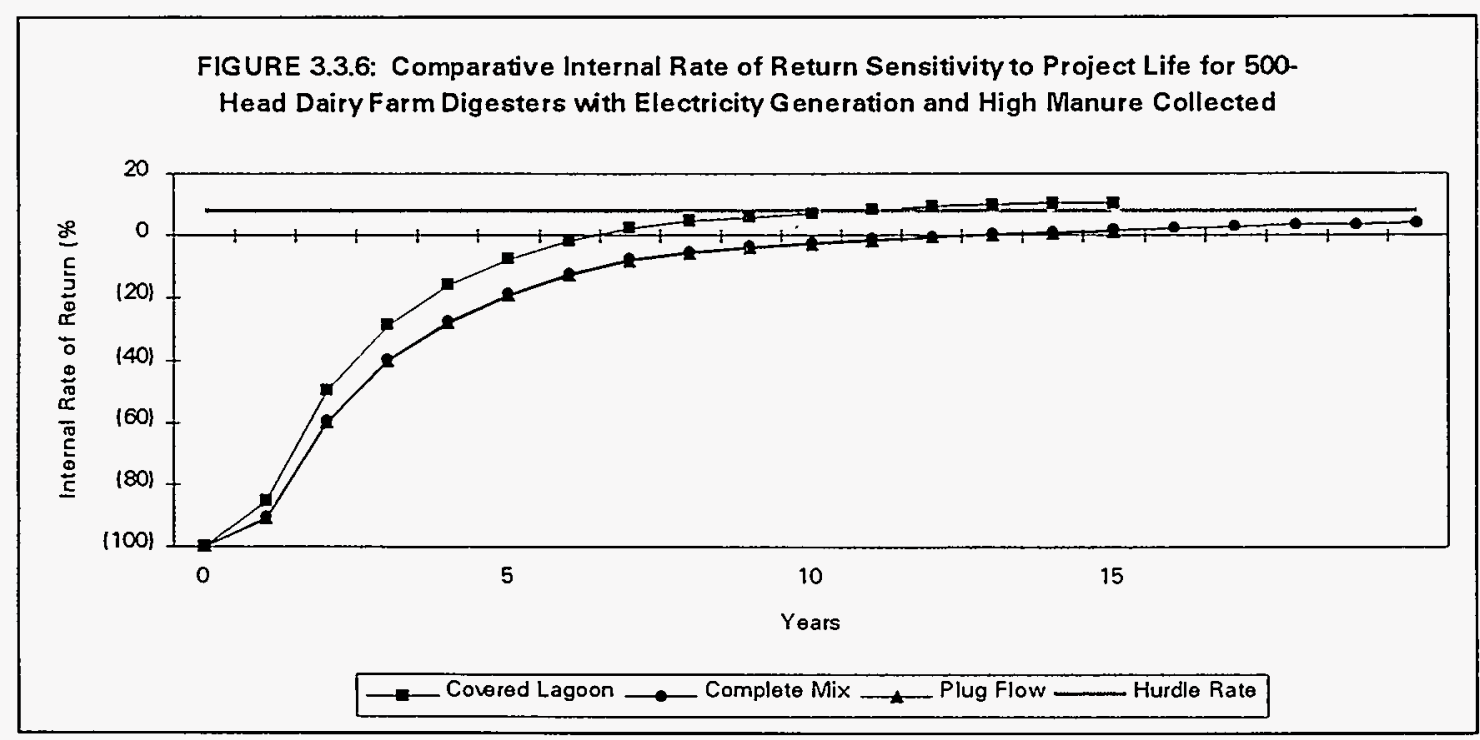

FIGURE 3.3.6: Comparative Internal Rate of Return Sensitivity to Project Life for 500 Head Dairy Farm Digesters with Electricity Generation and High Manure Collected

FIGURE 3.3.7: Comparative Cumulative Cash Flow for 1000-Head Dairy Farm Digesters with Electricity Generation and High Manure Collected
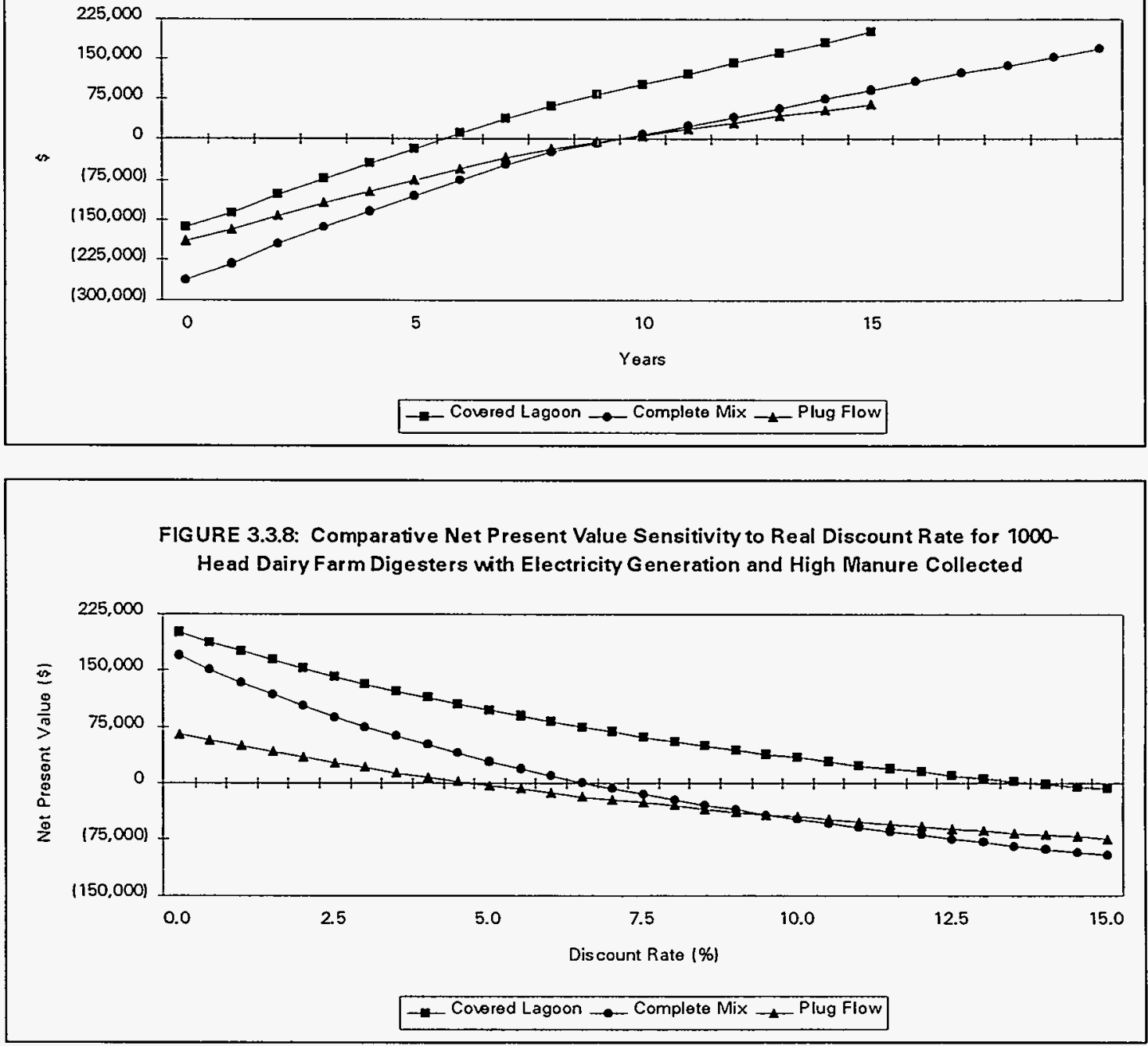


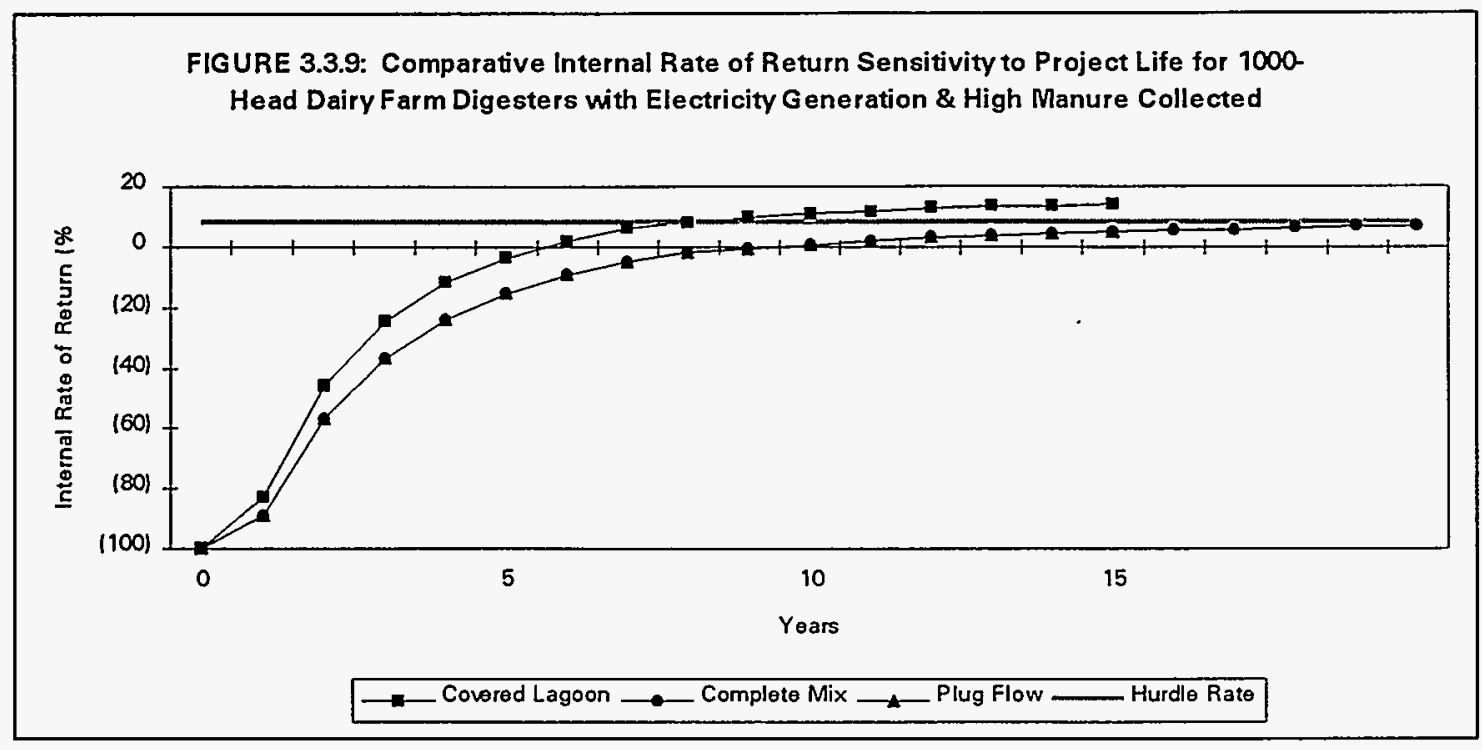

FIGURE 3.3.10: Cost Projection of Dairy Farm Covered Lagoon Digester with Electricity Generation and High Manure Collected
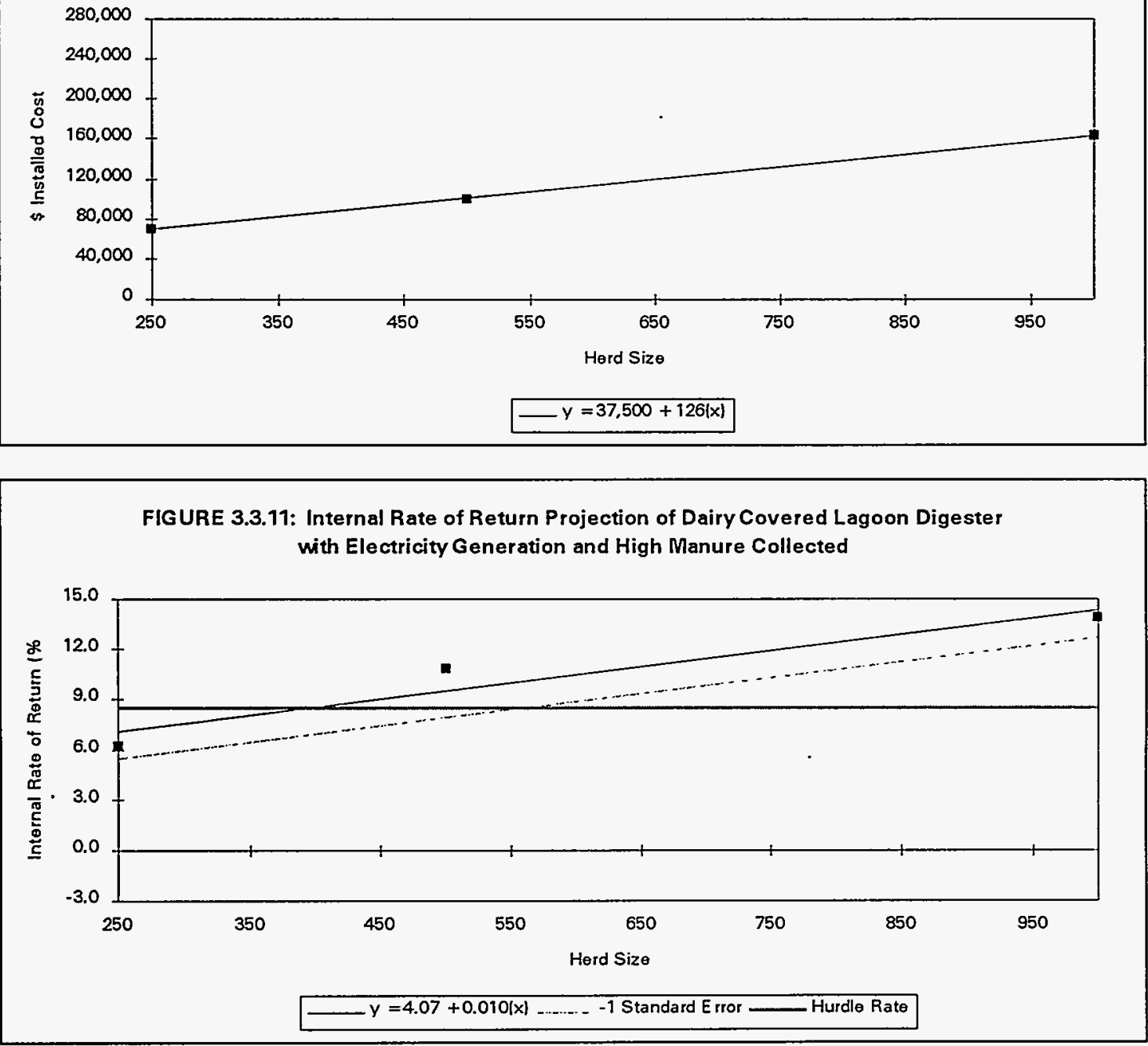
FIGURE 3.3.12: Cost Projection of Dairy Farm Complete Mix Digester with Electricity Generation and High Manure Collected
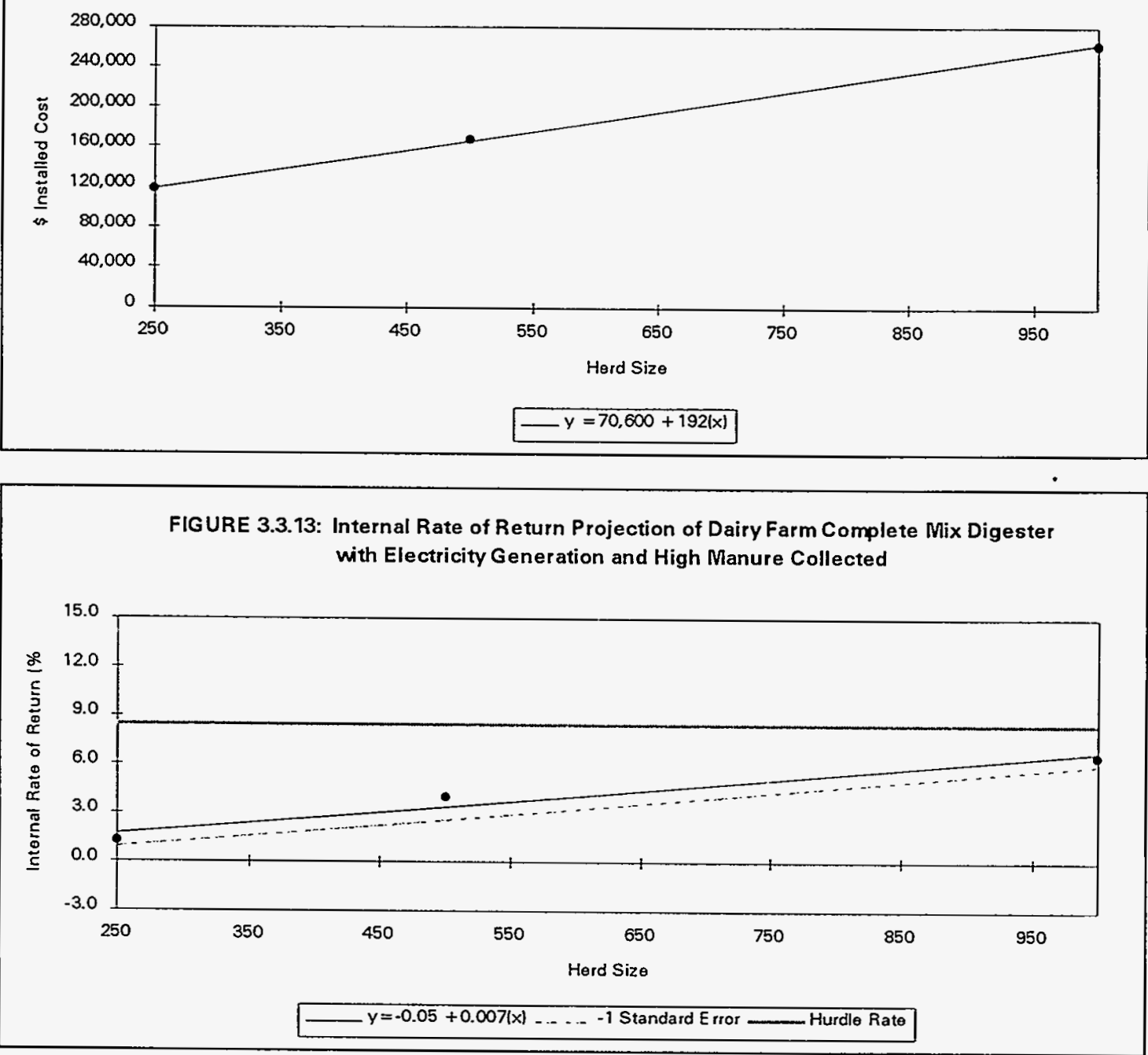

FIGURE 3.3.14: Cost Projection of Dairy Farm Plug Flow Digester with Electricity Generation and High Manure Collected

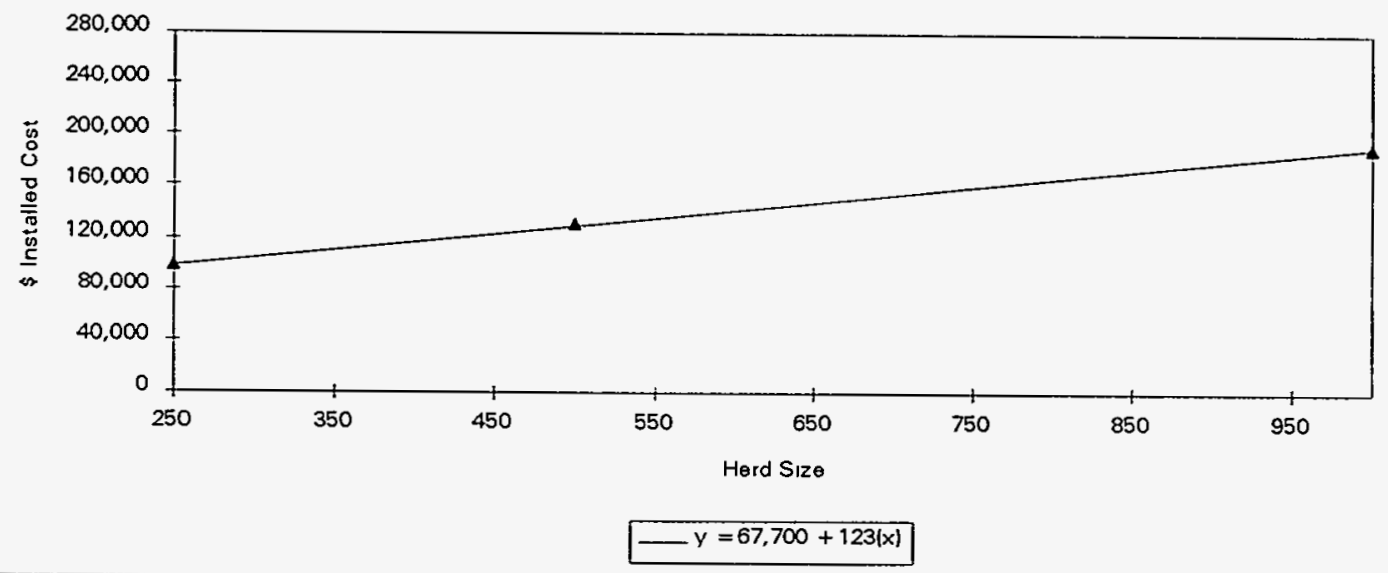




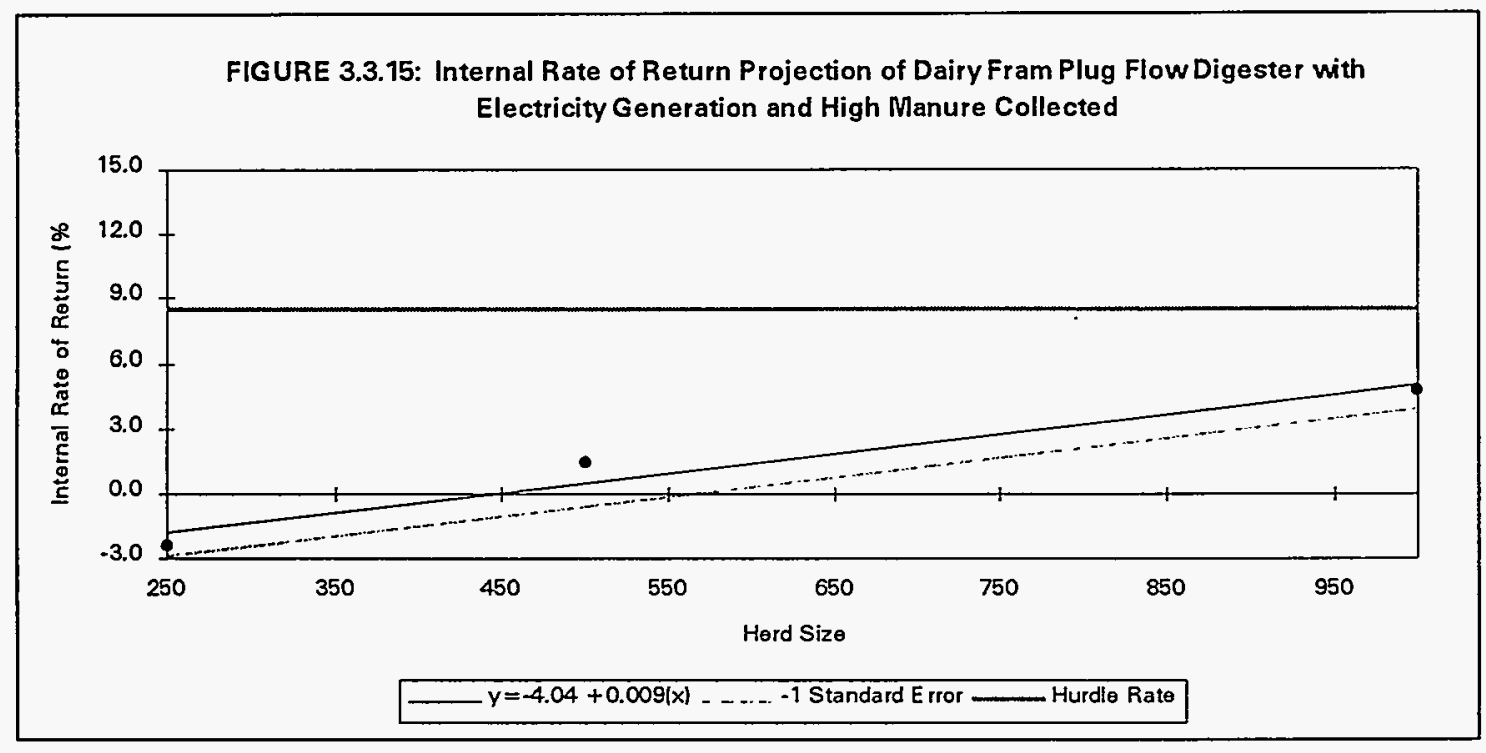

FIGURE 3.4.1: Comparative Cumulative Cash Flow for 500-Head Swine Farm Digesters with Electricity Generation and Al Manure Collected

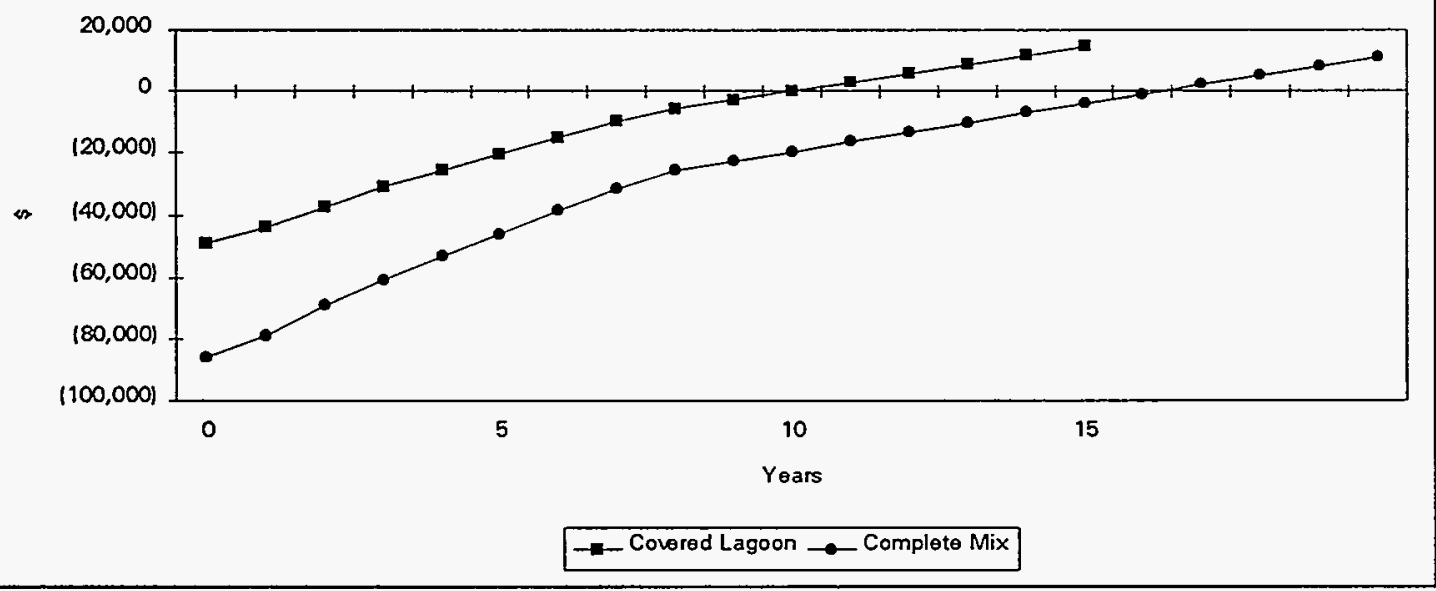

FIGURE 3.4.2: Comparative Net Present Value Sensitivity to Real Discount Rate for $500-$ Head Swine Farm Digesters with Electricity Generation and All Manure Collected

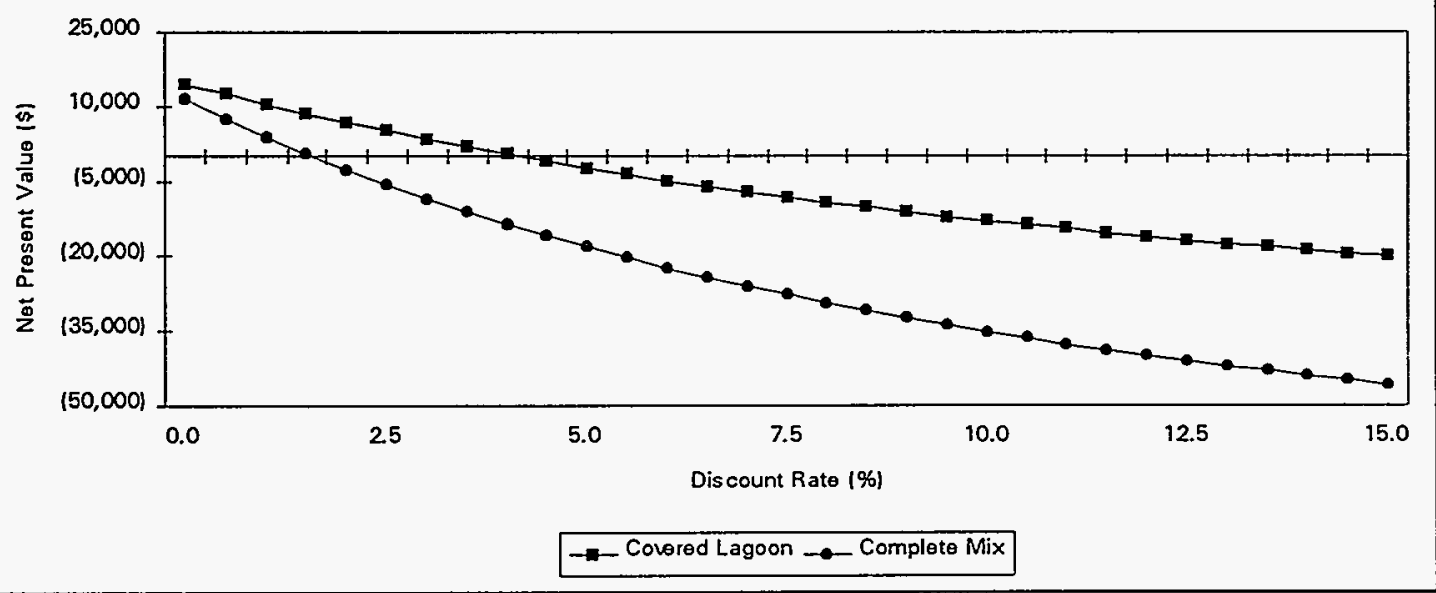




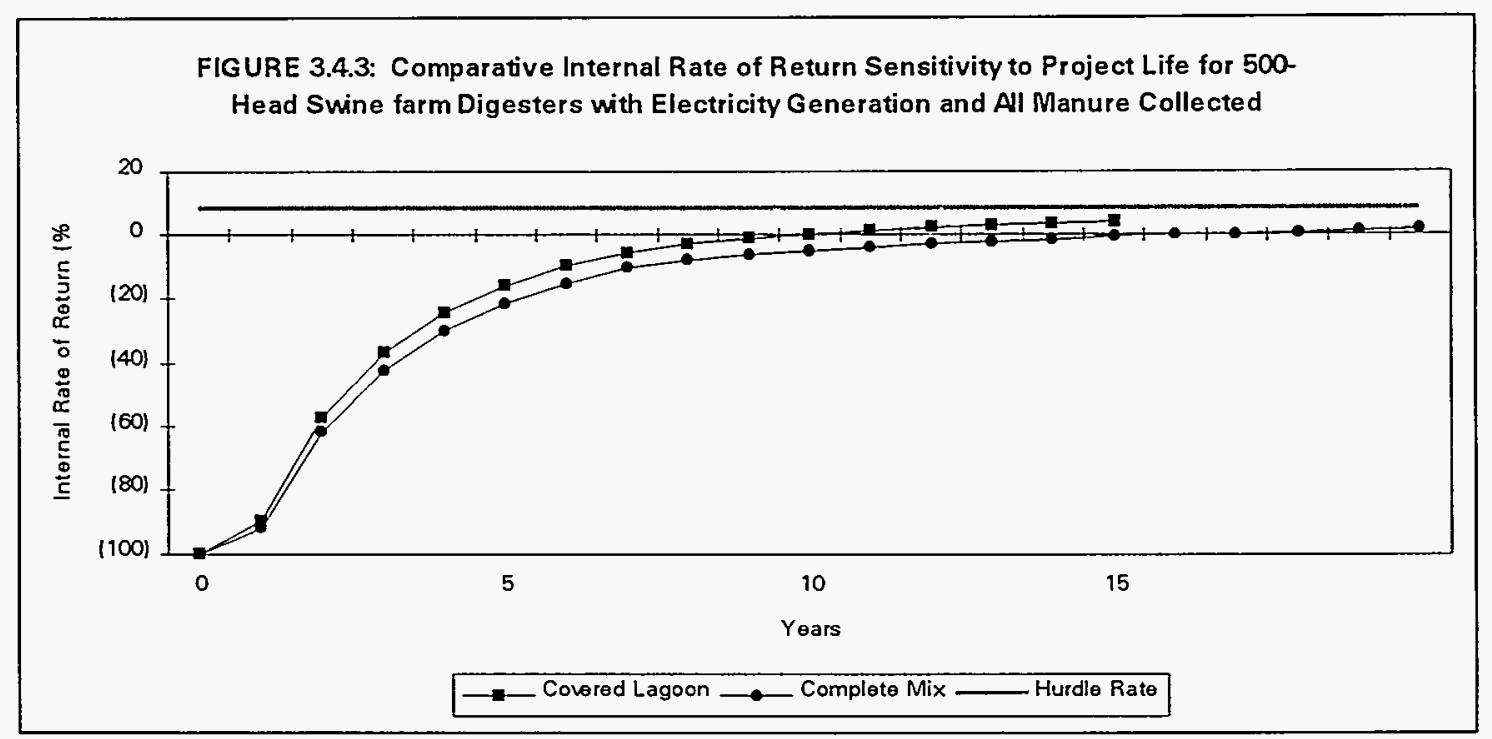

FIGURE 3.4.4: Comparative Cumulative Cash Flow for 1000-Head Swine Farm Digesters with Electricity Generation and Al Manure Collected
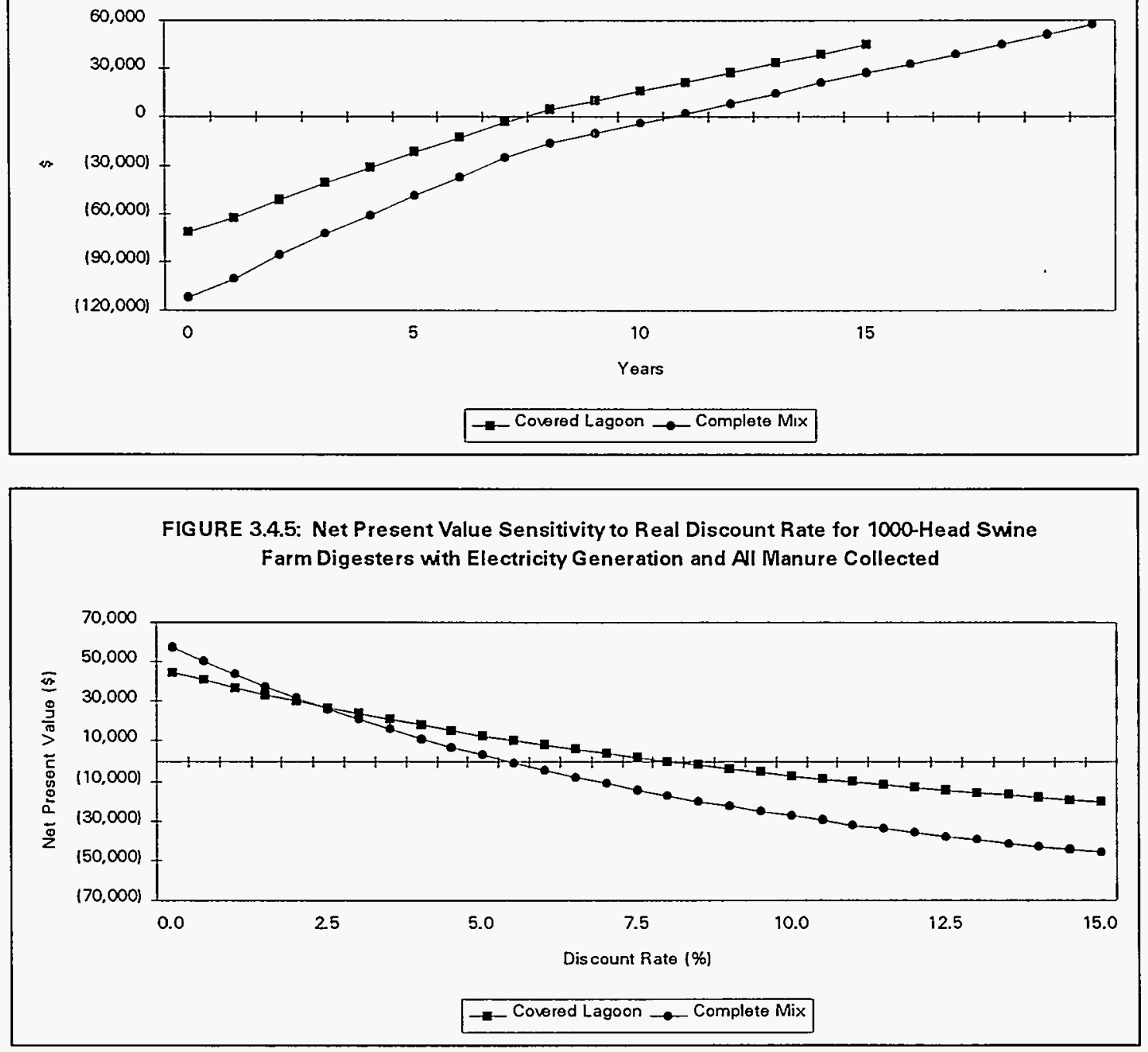
FIGURE 3.4.6: Comparative Internal Rate of Return Sensitivity to Project Life for 1000-

Head Swine Farm Digesters with Electricity Generation and Al Manure Collected

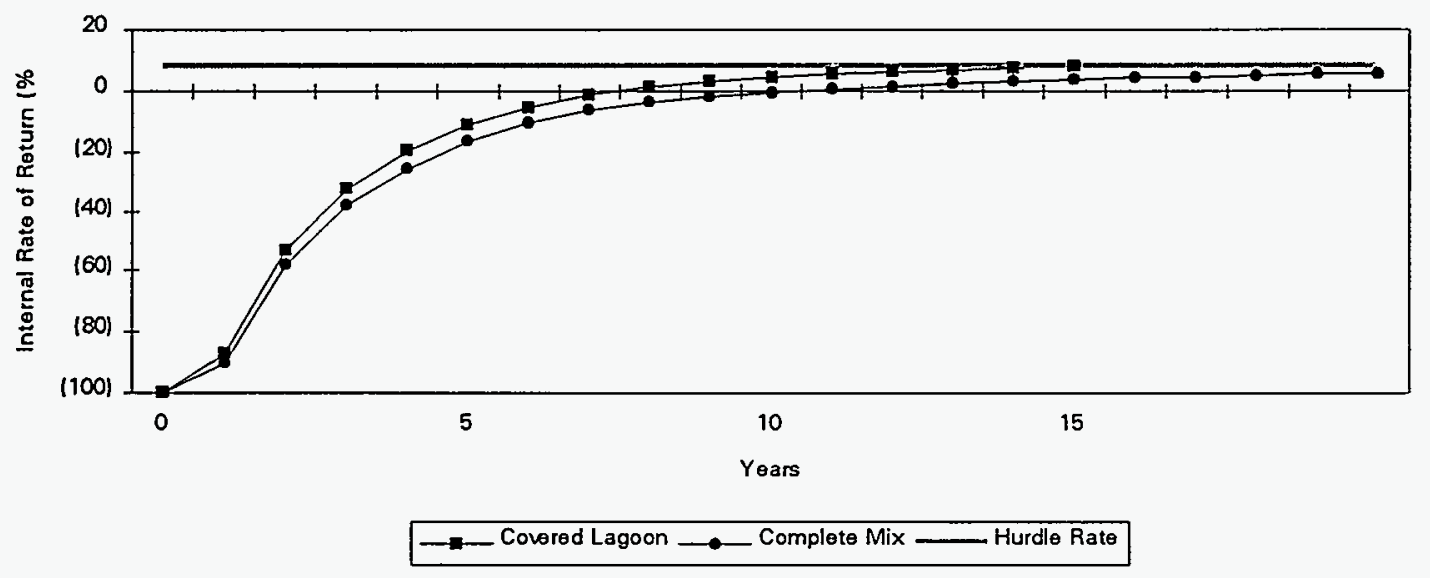

FIG URE 3.4.7: Comparative Cumulative Cash Flow for 5000-Head Swine Farm Digesters with Electricity Generation and Al Manure Collected

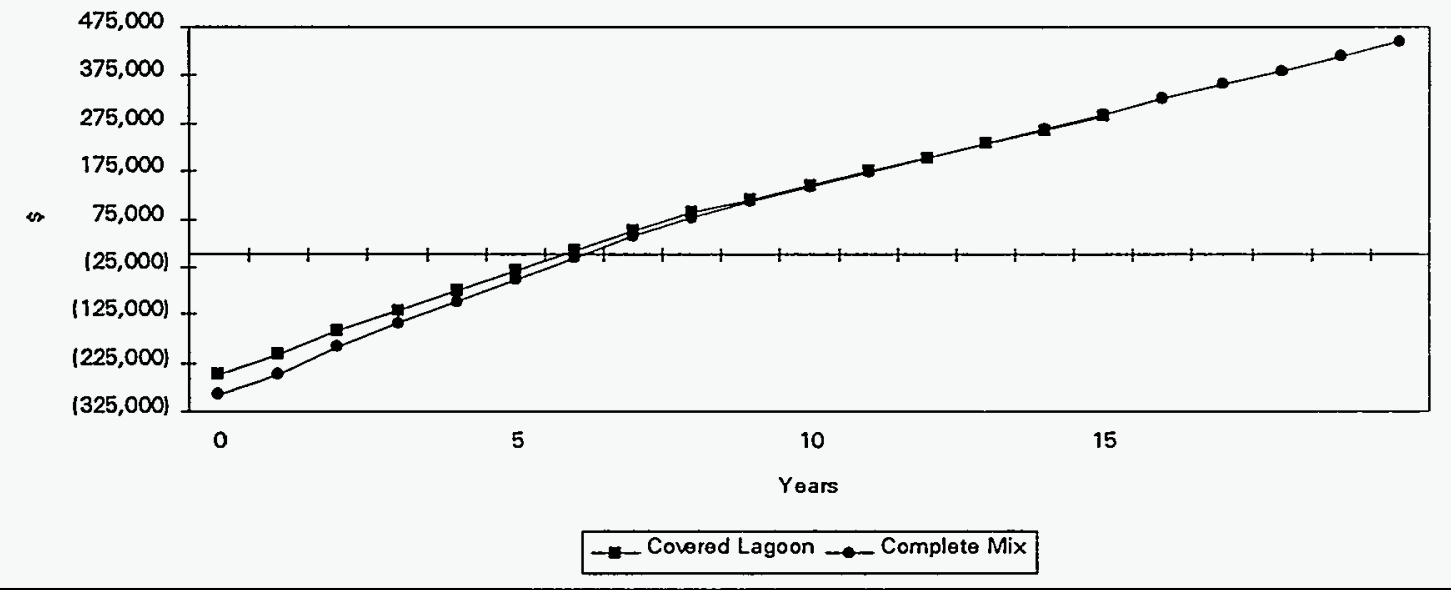

FIGURE 3.4.8: Comparative Net Present Value Sensitivity to Real Discount Rate for 5000 Head Swine Farm with Electricity Generation and AI Manure Collected

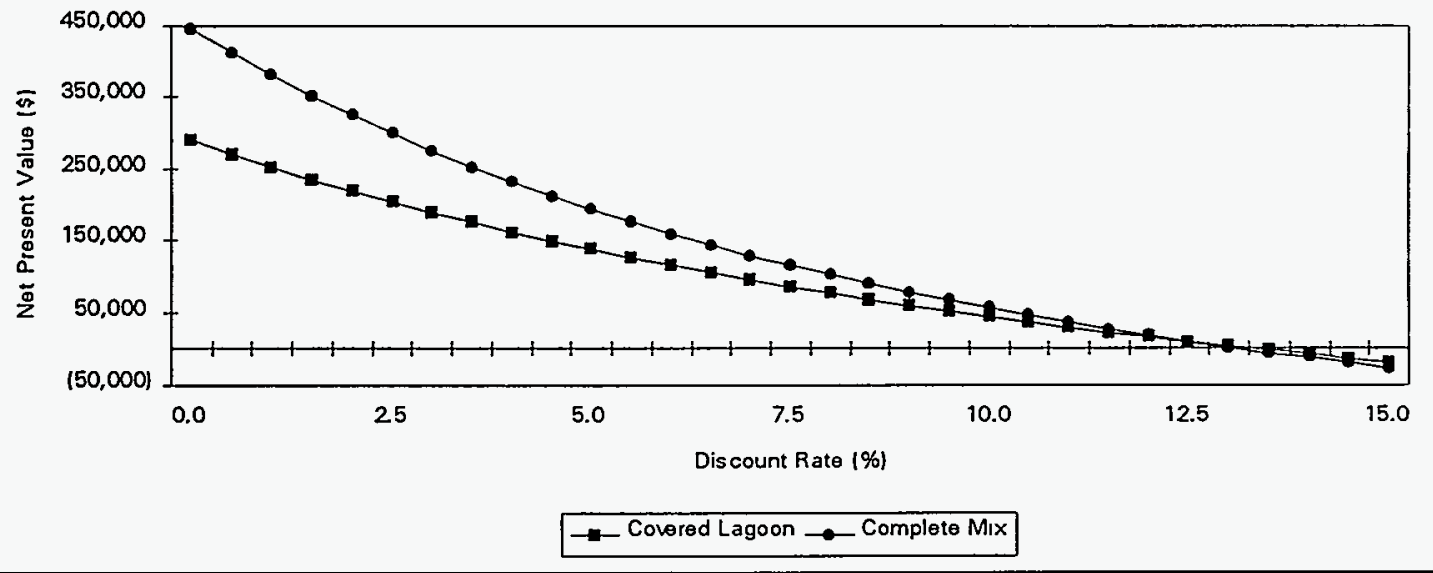




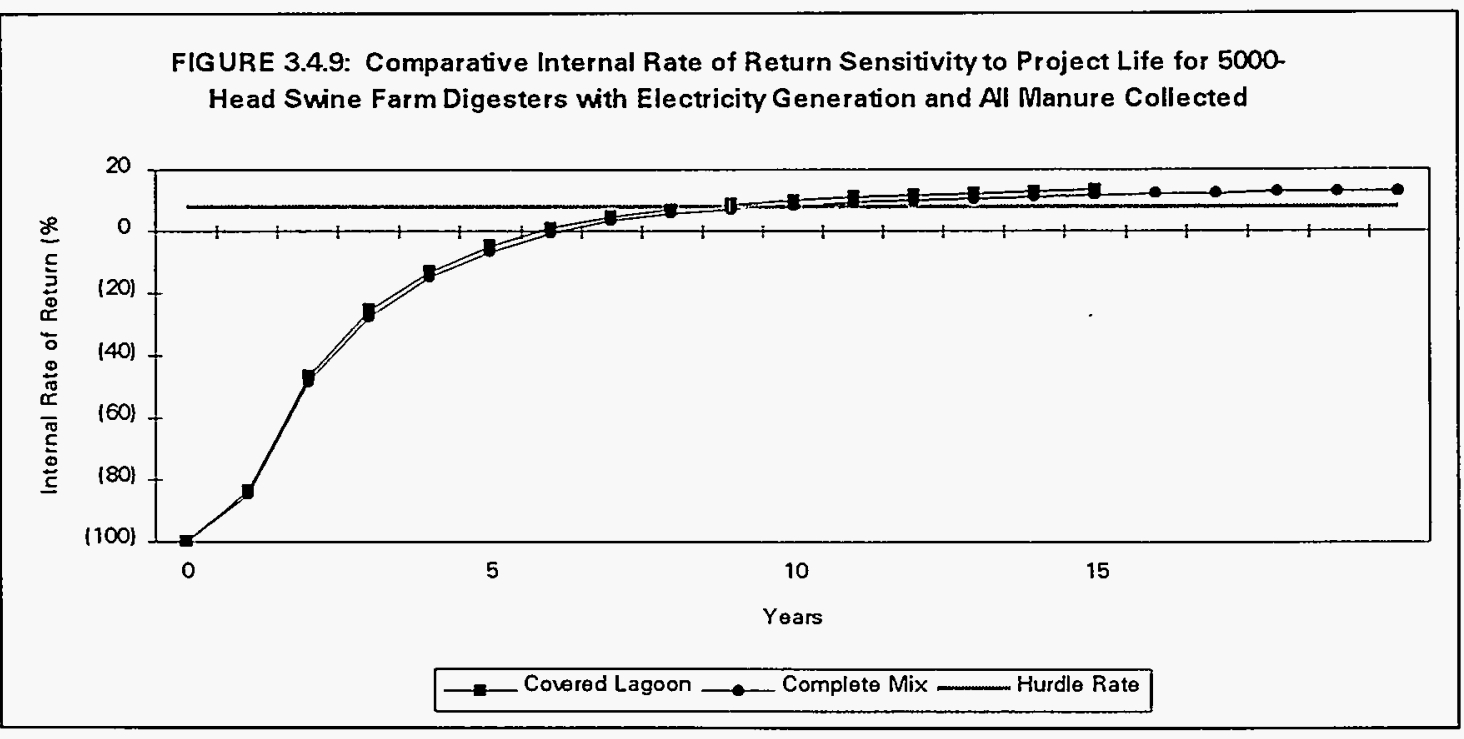

FIGURE 3.4.10: Cost Projection of Swine Farm Covered Lagoon Digester with Electricity Generation and All Manure Collected

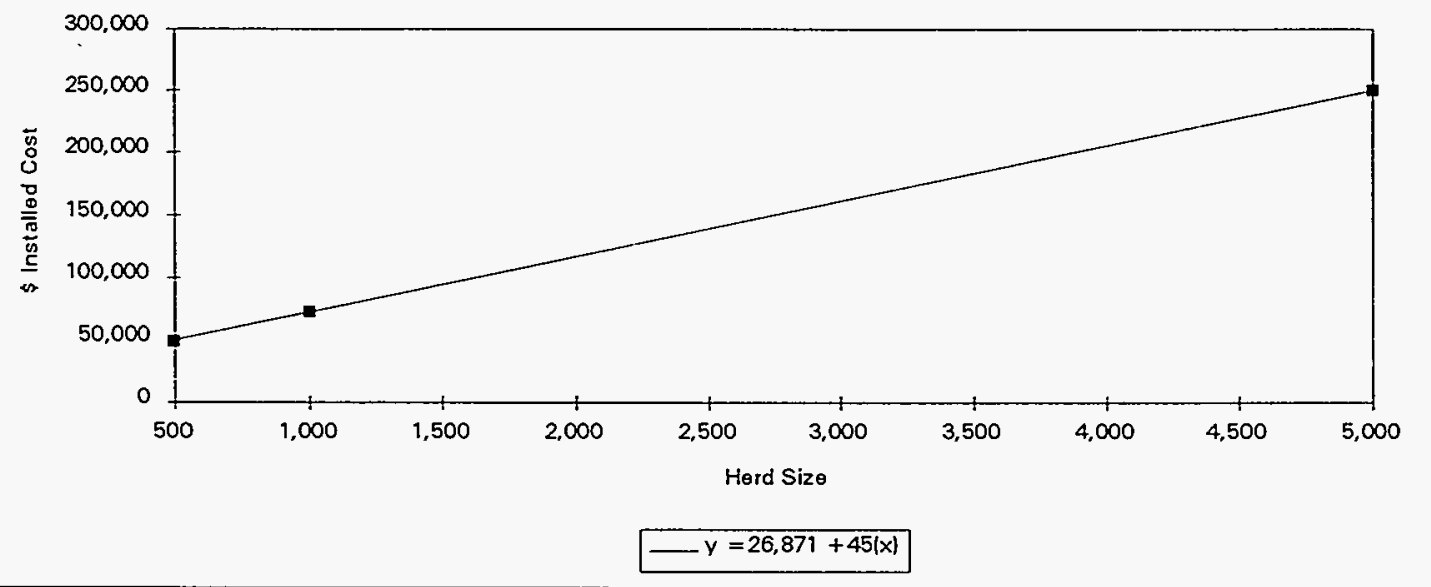

FIGURE 3.3.11: Internal Rate of Return Projection of Swine Farm Covered Lagoon Digester with Electricity Generation and Al Manure Collected

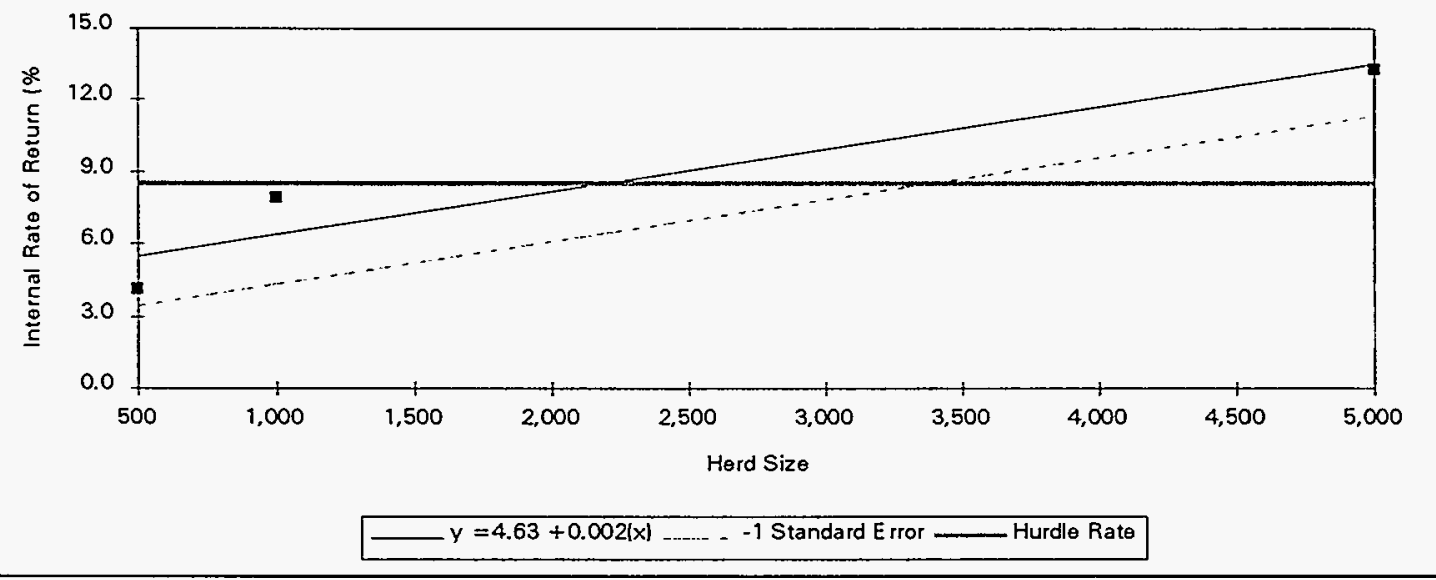


FIGURE 3.4.12: Cost Projection of Swine Farm Complete Mix Digester with Electricity Generation and Al Manure Collected

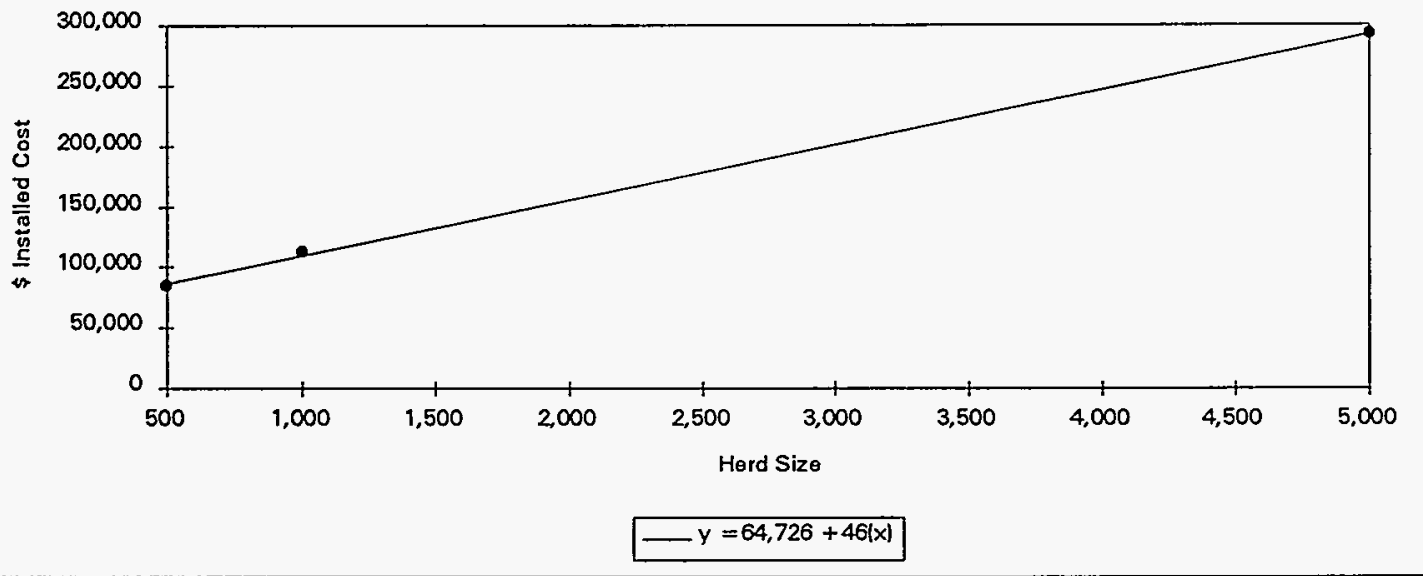

FIGURE 3.4.13: Internal Rate of Return Projection of Swine Farm Complete Mix Digester with Electricity Generation and AI Manure Collected

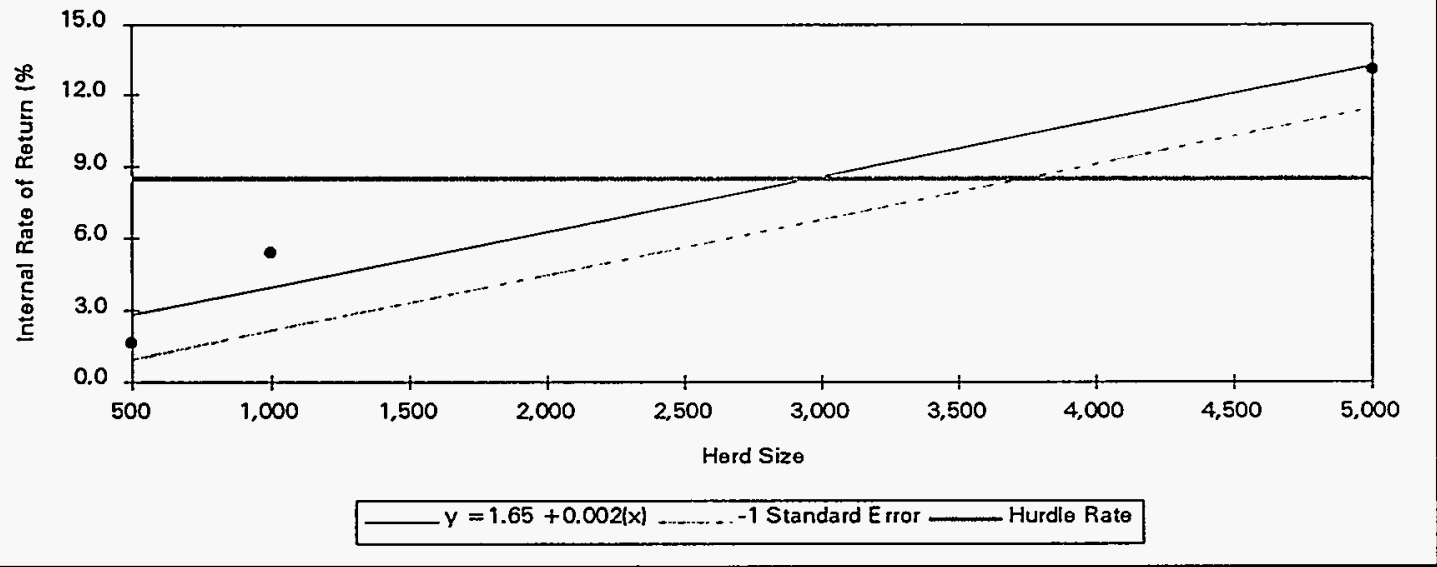




\subsection{CASE STUDIES OF ANAEROBIC DIGESTION PROJECTS}

To provide a reality base to the economic evaluations presented in the previous section, a number of operating and non-operating anaerobic digestion systems were surveyed using site visits or literature review. Some of the digester systems visited are outlined below as Case Studies to provide information on actual project and maintenance histories, and on the operator's "lessons learned". The Case Studies are presented in chronological order by their operational date.

Below, Figure 4.1 provides a numerical status report of farm-based anaerobic digesters in the US $^{1}$. The data presented includes the digesters that are installed on or were planned for working dairy, poultry, and swine farms. It excludes 65-70 digesters that are installed on or were planned for beef farms, and those digesters which are primarily university research-oriented.

The numerical status is not the whole story. Those surveyed farmers who have installed and continue to operate an anaerobic digester are generally satisfied with their investment decision. Some chose to install a digester for non-economic reasons, primarily to control odor or contain excess nutrient run-off. Farmers have found that the returns provided from electricity and other co-product sales from the digester, however limited, are preferred to the sunk-cost of conventional disposal which provides zero return on investment. Moreover, without the environmental benefits provided by anaerobic technology, some may have been forced out of livestock production. Anaerobic digestion is sometimes the only technology that allows growth in the livestock production business. Turning a waste liability into a profit center that generates annual revenues can

$1 \quad$ Modified from ICF Consulting Associates (1992) US Anaerobic Farm Digester Study. Unpublished report prepared for the US Environmental Protection Agency. Modified by Resource Development Associates (1994). moderate the impacts of declining commodity prices and can diversify farm income.

None of the farmers surveyed to date with an operating anaerobic digester said that they regret their basic decision. Most would have preferred to spend less money on its design and installation, but they are unsure of exactly how costs could have been cut. Many seek new ways to increase profitability by the sales of co-products, primarily the digested solids. They would like additional assistance in determining how best to optimize the added-value of co-products. Beating the odds, a few have met the challenge of making their systems work despite bad design or equipment. The hard knock of practical experience makes them the true superstars of farm-based anaerobic digestion technology in the US.

Still, at face-value, the performance data in Figure 4.2 is not encouraging to a farmer considering whether to install an anaerobic digester as a waste treatment option. Overall, the chance for failure, i.e., having a nonoperating anaerobic digester, is 65 percent in the US. This is roughly two times greater than the possibility of successfully employing a working digester. Excluding those that were never built, among the individual types of farmbased digesters, the failure rate for complete mix and plug flow technologies is a staggering 75 percent. For covered lagoon digesters, the failure rate is 30 percent. Because there are far fewer operating slurry digesters, their current 100 percent success rate is certainly inconclusive. Once slurry digesters have a larger market share, the opportunity for system failures due to poor design, fabrication, and operation will equal that for the other technologies, and the slurry's performance can then be gauged.

The reasons for digester failure go beyond bad design or equipment; many digesters in the US were shut down because farms were sold or energy prices declined. One encouraging note is that reliability of the digesters constructed since 1982 is far better than those digesters constructed during the period 1972-1982. This is generally due to a more simplified digester design. 
Lessons Learned:

they are not plugged, and checking to make sure biogas is being flared. Ten years ago, the digester was cleaned to remove built-up solids. The original cast iron input, discharge, and access port pipes were replaced with PVC, because the iron had degraded from scoring at the water level in the digester. Because convective currents produced by the heat exchanger produce sufficient agitation in the digester to avoid crusting problems, the rotary compressor system is no longer being used. Two additional backup systems--a mechanical agitation system for breaking up severe crusting and an auger extractor to be used in case the slurry becomes gelatinous--have never been needed. Overall, the system has experienced few problems. The only concern is that the amount of biogas produced must be balanced with the digester water flow rate.

On-farm anaerobic digestion works and is effective in controlling odors. The disposal of sludge produced as a result of the digestion process does not require taking land out of cultivation. The biogas produced can be a valuable co-product, but only those who are willing to commit to consistent monitoring should build a digester.

COSTING INFORMATION

Siting Cost:

Capital Cost:

Annual O\&M Cost:

End-Use of Biogas:

Prime Mover Type:

ANNUAL SAVINGS

Electricity Production:

Electricity Offsets:

Thermal Production:

Thermal Offsets:

End-Uses of Effluent:

Other System Savings:

DESIGNER/INSTALLER:
Included in capital cost.

$\$ 20,000$ for materials, plus labor. About two years were spent in selfeducation, locating equipment, and construction.

$\$ 2,500$ for natural gas.

Flared.

Not applicable.
Not applicable.

Not applicable.

Not applicable.

Not applicable.

Twice a year, before corn planting in the spring and before freezing in the fall, about 9,000 gallons of effluent and sludge are removed from the digester and land applied. Since $60 \%$ of the solids in the swine manure are digested, the storage lagoon has not been cleaned out since the digester was installed 22 years ago. The remaining solids primarily consist of lignin, which acts as a soil tilth and conditioning agent. This easily handled solid material is pure and odor-free.

Odor and pollution control. "I'm still in hogs."

Harold McCabe. 
Lessons Learned:

as necessary, especially engine valve guides. There has been one manual clean-out of Plug 1 to remove lime and gritty solids.

Would go straight to loop digester design because of reduced capital and O\&M costs. The loop digester has less outside surface area than a plug flow digester, so parasitic heating requirements are minimized. Also, the loop digester has heat pipes installed on a center wall, so the convective currents are greater than those in a plug flow digester. As a result, there is no need to agitate the loop digester, and also, the crusting problem associated with the plug flow digester is avoided.

COSTING INFORMATION

Siting Cost:

Capital Cost:

Annual O\&M Cost:

End-Use of Biogas:

Prime Mover Type:
Not available.

$\$ 180,000$ for the first plug flow system installed in $1979^{1}$. Modifications to the engine/generator and effluent handling system cost an additional $\$ 80,000$. Operator estimates the turnkey capital cost required to build a new loop system that would replace the three current units is $\$ 250,000$.

Not available.

Electricity with thermal reclaim used for heating digester and a nearby home.

Original was a Detroit Diesel system that was replaced after 5500 hours of operation with two $150-\mathrm{kW}$ model 342 Caterpillar LP gas enginegenerators. These engines operate with gold-tipped spark plugs. The engine ignition is retarded by 21 degrees, and the engines have modified carburetors to account for the lower energy content of biogas. Two additional Caterpillar engines are installed with a combined $400-\mathrm{kW}$ rating.

\section{ANNUAL SAVINGS}

Electricity Production:

Electricity Offsets:

Thermal Production:

Thermal Offsets:

End-Uses of Effluent:

Other System Savings:

DESIGNER/INSTALLER:

\section{PLUG 2 AND LOOP 1}

Estimated between 1.5 to 1.7 million $\mathrm{kWh}$

Previously estimated ${ }^{1}$ at $\$ 68,000$. Currently estimated at $\$ 92,000$, including sale of excess electricity generated. \$0.06 is the current $\mathrm{kWh}$ charge, with no demand charge.

Not available.

Not available.

Liquids used on croplands, and digested solids are sold to local nurseries.

Use of digester greatly reduces fly and odor problems. The system eases waste clean-up and reduces labor expenses. The digestion process adds to the solids value by killing weed seeds and increasing the plant nitrogen availability of the liquids used for land application.

Energy Cycle, Inc. (Plug 1).

Mason Dixon Farms.

1. Ashworth, J. (1985) Universe of US Commercial-Scale Anaerobic Digesters: Results of SERI/ARD Data Collection. Prepared by Associates in Rural Development for the Solar Energy Research Institute. 


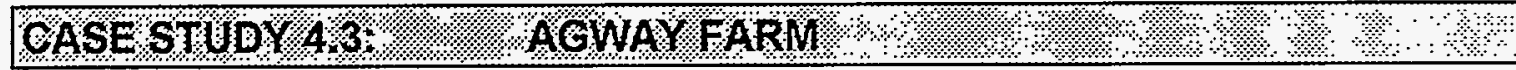

\begin{tabular}{ll|}
\hline CONTACTS & Stan Weeks \\
\hline Address: & Agway Farm Research Center \\
& 6978 Route 80 \\
& Tully, NY 13159-9513
\end{tabular}

Telephone: $\quad 3156835700$

\section{GENERAL SYSTEM INFORMATION}

Herd Type: Dairy.

Herd Size:

500 total head with 250 milkers.

System Type:

Dimensions:

Capacity:

Gas Production:

Operational Date:

Estimated Life:

Current Status:

Project History:

Maintenance History:
Vertical concrete slurry tank with no mechanical mixing.

28 feet $\times 20$ feet diameter.

7,225 cubic feet working volume ${ }^{1}(54,000$ gallons).

12,000 cubic feet of biogas per day average (60\% methane content).

1981.

20 years.

Operational.

The Agway project is the result of management's interest in evaluating the technology in the wake of the optimism surrounding anaerobic digestion technology in the 1970's. Operating experiences here, using the wastes of 170 milkers, and at two other developmental locations, have been used to improve system design and to define operating economics. Prior to 1987 , the digester system handled a smaller volume and was constructed with concrete staves. Due to its size and less than desirable construction, the digester was replaced with a larger, poured-concrete design. Inside the current digester..." a vertical dividing wall separates the point of manure entry and exit. No mechanical mixing of the digester contents occurs within the digester. Manure is mixed by thermal activity fostered by a concentrating heat pipe on a[n]...interior wall. The effluent is displaced by incoming manure and flows by gravity from the top of the digester into the adjoining manure storage. Some of the solids can be diverted into the adjoining manure storage ${ }^{i_{\mu \prime}}$.

Daily operation and maintenance requirements are minimal, requiring about 10-15 minutes on average. Follows a consistent data collection protocol to monitor system performance. Parameters include checking condensate, digesters and engine temperatures, engine oil levels, engine oil pressure, and recording biogas production. Schedules major system overhauls annually, including the engine and removing built-up solids from the digester. 
Lessons Learned:

The basic overhaul requires 2-3 days, and the recovery of the digester system might add 3-4 more days. This procedure enables the system to consistently maintain a 95 percent availability factor.

Initially used a concrete stave silo digester with a fiberglass roof, and a Fiat TOTEM engine/generator that required a biogas scrubber and gas compressor. Standard design now consists of a poured epoxy-coated concrete silo, four inches of urethane foam, and a special sealant inside the urethane to provide a gas- and liquid-tight interior surface. This allows for higher pressures inside the digester that directly feeds the engine/generator without need for a compressor. No longer scrubs biogas to remove hydrogen sulfide. Instead, relies on frequent oil changes and keeps the engine hot by running it 24 hours per day as the best method to reduce corrosion. Insulated housing area reduces the frozen manure problem in the winter and also allows for greater winter biogas production. Converted system to separate solids before introduction into the digester in order to make materials handling easier.

COSTING INFORMATION

Siting Cost: Included in capital cost.

Capital Cost:

$\$ 175,000$ (about $\$ 1000$ per cow).

Annual O\&M Cost:

Estimated to be $\$ 3,650$.

End-Use of Biogas:

Electricity with thermal reclaim used for digester and two buildings.

Prime Mover Type:

18-kW 4-cylinder Mercruiser (GM) marine engine modified by Perennial Energy.

ANNUAL SAVINGS

Electricity Production:

Estimated between 145-150 thousand kWh.

Electricity Offsets:

Estimated between $\$ 17,000$ to 18,000 . $\$ 0.12$ is the current $\mathrm{kWh}$ charge, with no demand charge.

Thermal Production:

"From the available data, it appears that about 30 percent of the energy in the biogas is recovered as hot water..." ${ }^{\prime \prime}$. This is estimated to be the equivalent of 8000 to 8400 gallons of propane gas.

Thermal Offsets:

Estimated between $\$ 5,600$ to $\$ 5,800$ at $\$ 0.70$ per gallon of propane.

End-Uses of Effluent:

Digester effluent goes to a storage area to be land-applied. Fertilizer value is estimated to be $\$ 100$ per cow per year, but the value cannot be entirely attributed to the digester.

Other System Savings:

Odor control is a significant advantage because the digestion process nearly eliminates the volatile acids present in raw manure.

DESIGNER/INSTALLER: Agway.

1. Koelsch, et al. (1988) On-Farm Biogas Systems Information Dissemination Project. 175 pages. 


\section{CASE STUDY 4 . \% SARGROVE FARMS, INC}

\begin{tabular}{ll}
\hline CONTACTS & David or John Pueschel \\
\hline Address: & Fairgrove Farms, Inc. \\
& 6770 Balk Road \\
& Sturgis, Ml 49091
\end{tabular}

Telephone:

6166516646

\section{GENERAL SYSTEM INFORMATION}

Herd Type:

Dairy.

Herd Size:

700 total head.

System Type:

Plug flow.

Dimensions:

Not available.

Capacity:

24,000 cubic feet (180,000 gallons). ${ }^{1}$

Gas Production:

$35,000^{2}$ to $50,000^{1}$ cubic feet of biogas per day $160 \%$ methane content).

Operational Date:

1981.

Estimated Life:

20 years.

Current Status:

Operational.

Project History:

Maintenance History:

"This system is innovative in its construction. Most on-farm systems use a lined lagoon or tank with a soft plastic cover that can degrade or require special maintenance. The Fairgrove system has had no such problems. It has an insulated stress-core top over a (four inch) concrete cover, interrupted only by a baffle inspection hole. Further, the tank is buried under two feet of soil." 1

"The system has experienced few problems. Sand settling out of the waste feedstock has sometimes accumulated around the heat exchanger and blocked effective digester heating. Operators solve this problem by cleaning the heat exchanger system every three years." 1 Ashworth ${ }^{2}$ reported that trapped sand caused the heat exchanger to break. $\mathrm{ICF}^{3}$ reported that the operator's spend about five minutes per day maintaining the engine/generator system. Hydrogen sulfide in the biogas is not scrubbed before fueling the engine/generator and " $(t)$ his problem is addressed with extra maintenance." 1 This extra maintenance is presumed to be more frequent oil changes than might be conducted at a facility that removes hydrogen sulfide prior to combustion.

Lessons Learned:

"The value has been unquestionable, measured in terms of energy savings, waste management, and the production of valuable [co-] products for use as bedding and fertilizer. If there is a secret to the 
success of this system, operators say it is the use of a hard-covered, well-built digester tank, and the relative absence of trouble-prone 'bells and whistles'." 1

COSTING INFORMATION

Siting Cost:

Capital Cost:

Annual O\&M Cost:

End-Use of Biogas:

Prime Mover Type:
Included in capital cost.

$\$ 200,000$.

$\$ 25,407$, but this includes system depreciation $(\$ 15,000)^{2}$.

Electricity production with thermal reclaim used for digester heating.

85-kW model 3306 Caterpillar modified by Perennial Energy.
ANNUAL SAVINGS

Electricity Production:

Electricity Offsets:

Thermal Production:

Thermal Offsets:

End-Uses of Effluent:

Other System Savings:

DESIGNER/INSTALLER:

NOTE:
Estimated between 435,000 and $620,000 \mathrm{kWh}$ at an $85 \%$ availability factor.

Estimated between $\$ 38,500^{2}$ and $\$ 42,000^{1}$.

Not available.

Not applicable.

Digester effluent is separated using a centrifuge. "Solids reclaimed at this stage have a consistency like sawdust and are used as stall bedding for the animals. This material is pure and relatively odor-free, Site managers say cows using this bedding have a lower incidence of some diseases [presumably mastitis] than they did using conventional bedding. The [liquid] effluent flows by gravity into a storage lagoon. Unlike most other anaerobic digestion systems, this system does not include a final sludge-drying process; the [liquid] residue is used as a fertilizer [and] spread directly on fields semi-annually." ${ }^{1}$ Ashworth reported that the annual value of other benefits was $\$ 18,000$.

None reported.

Perennial Energy, Inc.

This Case Study was constructed from the literature rather than an onfarm site visit.

1. Cliburn, et al. (1993) Biogas Energy Systems: A Great Lakes Casebook. Great Lakes Regional Biomass Energy Program, Council of Great Lakes Governors, Chicago, IL. 38 pages.

2. Ashworth, J. (1985) Universe of US Commercial-Scale Anaerobic Digesters: Results of SERI/ARD Data Collection. Prepared by Associates in Rural Development for the Solar Energy Research Institute.

3. ICF Consulting Associates (1992) US Anaerobic Farm Digester Study. Unpublished report prepared for the US Environmental Protection Agency. 
CASE STUBY $45 \%$ : 5 FOSTER BROTHERS FARM :

\begin{tabular}{lll|}
\hline CONTACTS & Robert L. Foster & Don Brumfield \\
\hline Address: & Foster Brothers Farm & Vermont Natural Ag Products \\
& RD \#3 Route 166 & 559 Lower Foote Street \\
& Middlebury, VT 05753 & Middlebury, VT 05753 \\
Telephone: & 8023886234 & 8023880156
\end{tabular}

GENERAL SYSTEM INFORMATION

Herd Type: Dairy.

Herd Size:

600 total head with 350 milkers.

System Type:

Dimensions:

Capacity:

Gas Production:

Operational Date:

Estimated Life:

Current Status:

Project History:

Maintenance History:

Lessons Learned:
Two (2) plug flow units with XR-5 cover material.

96 feet $\times 48$ feet $\times 7$ feet.

32,250 cubic feet $(241,000$ gallons $)$.

28,000 cubic feet per day ${ }^{1}$.

1982.

15 years.

Operational.

The project was initiated as a result of concerns regarding waste management and the energy crises of the 70's. The project was designed to accommodate frozen manure in the winter assembled from push-off areas at the free-stall barns. The digester labor requirement had to complement the labor requirement used in stall scraping and feeding chores. Adequate waste storage and ease of application were both important considerations. The plug flow design is viewed as having an advantage because uniform temperatures are not required throughout the digester, and the reduction in thermal stress of the bacteria provides a higher yield of biogas ${ }^{2}$.

The digester has had two manual clean-outs since 1982. Normal maintenance, consisting primarily of frequent engine oil changes, is also done on a scheduled basis. Biogas clean-up for removing hydrogen sulfide consists of limestone flakes in a plastic barrel. Minor mechanical pump failures, but no major problems, reported.

Use a single manufacturer for engine generator and related electrical switch gear. Put in a neck chain sump for mechanical clean-out, rather than rely on manual cleaning.
COSTING INFORMATION

Siting Cost: Not available. 
Capital Cost:

$\$ 185,000$ when installed in 1982. Modifications to the engine/generator and effluent handling have cost an additional $\$ 115,000$. Operator estimates costs for the full utilization of effluent solid materials may be $\$ 700,000$.

Annual O\&M Cost:

$\$ 8,000^{\prime}$ to $\$ 12,000$.

End-Use of Biogas:

Electricity production with thermal reclaim used for digester heating.

Prime Mover Type:

Original prime mover was a $125-\mathrm{kW}$ model 353 Caterpillar natural gas engine-generator. Although the original prime mover is still installed, lower buy-back rates for excess electricity led to the installation of a $85-\mathrm{kW}$ model 3304 Caterpillar diesel engine which was modified to operate on a dual-fuel (biogas \& diesel) basis for load displacement.

ANNUAL SAVINGS

Electricity Production:

Electricity Offsets:

Thermal Production:

Thermal Offsets:

End-Uses of Effluent:

Other System Savings:
Not available.

Previously estimated ${ }^{1}$ at $\$ 40,000$ when facility sold power. $\$ 0.28$ current on-peak $\mathrm{kWh}$ charge, with no demand charge.

Not available.

Not applicable.

Digester effluent is run through a screw-type dewaterer. Liquid effluent sprayed on fields with irrigation guns. De-watered solids are composted. Formerly used as bedding, solids are composted and are now sold as seven different soil amendments (potting soil, germinating mix, etc.) through Vermont Natural Ag Products, Inc.

Digester is centrally located on the farm, and is viewed as an integral component of the farm's waste management system. The digester generates a better product than other waste management options. Odor reduction is also viewed as a benefit of the system.

Hadley \& Bennett.

SYSTEM INSTALLER: Hadley \& Bennett.

1. Ashworth, J. (1985) Universe of US Commercial-Scale Anaerobic Digesters: Resu/ts of SERI/ARD Data Collection. Prepared by Associates in Rural Development for the Solar Energy Research Institute.

2. Foster, R. (1983) Integrating Methane Production and Irrigation Systems, 5 pages. 


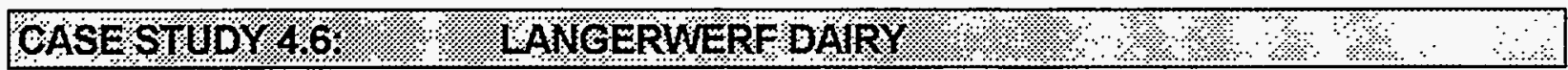

\begin{tabular}{ll|}
\hline CONTACTS & Leo \& Linda Langenwerf \\
\hline Address: & Langerwerf Dairy \\
& 1251 Durham-Dayton Highway \\
& Durham, CA 95938
\end{tabular}

Telephone:

9168933131

GENERAL SYSTEM INFORMATION

Herd Type: Dairy.

Herd Size:

700 total head with 350 milkers.

System Type:

Plug flow with Hypalon cover material.

Dimensions:

125 feet $\times 25$ feet $\times 14$ feet.

Capacity:

43,750 cubic feet $(327,000$ gallons $)$.

Gas Production:

30,000 cubic feet per day $\left(60 \%\right.$ methane content). ${ }^{1}$

Operational Date:

1982.

Estimated Life:

20 years.

Current Status:

Operational.

Project History:

The project was initiated to take advantage of the California Department of Food and Agriculture's low-interest loan program that was available to dairies for the installation of anaerobic digesters as an alternative waste management tool. After examining several systems, a plug flow was selected because the digested solids could be more readily recovered before discharge into a storage pit after scrape collection. This reduced some of the problems and expenses associated with using spreader trucks which previously pumped materials from the storage pit for land application. The project was slowed in its initial start-up due to a lack of labor and knowledge of system operation. The digester is housed in an innovative low-cost greenhouse, which protects it from wind damage and rainwater collection.

Maintenance History:

Normal maintenance consists of a visual inspection of the digester solids loading rate (11-14\% solids is desired) and engine/generator oil levels. The biogas is filtered through an mercaptan filter to remove hydrogen sulfide prior to combustion.

Lessons Learned:

The main project drawback was its investment cost, although there were problems associated with learning proper digester operating temperature, $\mathrm{pH}$, and feeding requirements. There has been additional stress associated with equipment maintenance. Their experiences would lead the Langerwerf Dairy to the decision to build another 
digester to provide biogas supplies in order to operate the engine/generator closer to rated capacity, if funding were available.

COSTING INFORMATION

Siting Cost: Not available.

Capital Cost:

$\$ 200,000$, which included the digester, solids separating system, and all ancillary equipment. One-half of the project was funded using a low interest loan. The balance of project costs were funded with a commercial loan through the local Production Credit Association.

Annual O\&M Cost: $\quad$ Not available.

End-Use of Biogas: $\quad$ Electricity production with thermal reclaim used for milking facility hot water heating and residential space heating.

Prime Mover Type: $\quad 85-\mathrm{kW}$ model 3306 Caterpillar engine, which generally operates at a load displacement level of 40-kW.

ANNUAL SAVINGS

Electricity Production:

Electricity Offsets:

Thermal Production:

Thermal Offsets:

End-Uses of Effluent:

Other System Savings:

SYSTEM DESIGNER:

SYSTEM INSTALLER:
Estimated at $300,000 \mathrm{kWh}$.

$\$ 36,000$ currently. $\$ 0.12$ is the current $\mathrm{kWh}$ charge, with no demand charge. Savings were estimated at $\$ 40,000$ annually when the facility was initiated due to the former avoided cost rate of the electric utility.

Not available.

$\$ 15,000$, with hot water heating savings estimated to average about $\$ 1,000$ per month.

Liquids are pumped into an irrigation line and land applied on a yearround basis. Separated solids are used for freestall and calf barn bedding and also sold as garden mulch to local gardeners at $\$ 5.00$ per yard. Any excess solids are spread onto fields during planting to increase soil tilth.

Manure solids sales are approximately $\$ 5,000$ per year. Savings resulting from reduced number of manure pit clean-outs are estimated to be $\$ 12,000$.

Resource Conservation Management, Inc.

Lee Miller.

1. Langerwerf, Leo (1989) Integrated Systems for Waste Management and Energy Generation: Langerwerf Dairy Biogas Generation System, 3 pages. 


CASESTUDY $47 \%$ / ROYAL FARMS $/$ ?

\begin{tabular}{ll|}
\hline CONTACTS & Roy Sharp \\
\hline Address: & Royal Farms \\
& 20174 Road 140 \\
& Tulare, CA 93274
\end{tabular}

Telephone:

2096882051

\section{GENERAL SYSTEM INFORMATION}

Herd Type:

Herd Size:

System Type:

Dimensions:

Capacity:

Gas Production:

Operational Date:

Estimated Life:

Current Status:

Project History:
Swine (farrow-to-finish).

16,500 total head with 1,650 sows.

Covered lagoon with Hypalon cover material.

205 feet $\times 205$ feet $\times 25$ feet.

$1,050,000$ cubic feet $(7,860,000$ gallons $)$.

70,000 cubic feet of biogas per day $(70-80 \%$ methane content).

1982.

20 to 30 years.

Operational.

The current waste management program started in 1972 with the objective of supporting a large animal population in a confined area that meets or exceeds public health and environmental standards. The need to reduce flies, dust, and odors led to the design and installation of a system using hydraulic waste flushing into a three-cell lagoon. The energy crisis predictions of high electricity prices precipitated a focus on renewable energy resources. Since biogas was known to be a by-product of the lagoon's digestion process, the California Energy Commission funded a feasibility study. Conventional complete mix and plug flow digesters were evaluated and rejected because of the desire for a low-cost digester, and the study led to the decision to install a system using a simple floating cover attached to a retaining wall on the first cell of the existing lagoon. Royal started with only a $1 / 3$ acre cover over the first-cell lagoon because of cost, and eventually covered the entire first cell and added a second engine/generator in 1987. Royal Farms borrowed the money to install the cover, and paid off the loan in two years. The greatest perceived benefit is that the technology is a complete waste management system, providing an $80 \%$ reduction in odors, with essentially no dust or flies on premises. Parlor effluents were measured at 10,000 to $15,000 \mathrm{ppm}$ at input to first cell, and at $25-50 \mathrm{ppm}$ during discharge from the third cell. Additionally, no nitrates were found in a ground water test done by the USDA. Royal Farms has not cleaned out the three-cell lagoon system since its construction in 1972. Given the success of this project, two other swine farms have also installed floating covers: Sharp Ranch (550 sows) and Caruthers Ranch (900 sows). A fourth facility using a floating cover is scheduled to come on-line during the fall of 1994. 
Maintenance History:

Lessons Learned:
Requirements for discharge pipeline has been zero because the system was installed correctly. Performance of the floating cover has been satisfactory, but some problems have occurred with wind and cover tie-downs. Very little cover puncture problems, and easily repaired because of type of cover material. Cover skirts were weighted at 6 feet, but will surface sometimes and cause a loss of biogas. A 5 -minute daily inspection is average, but may not investigate for 4 or 5 days in a row. A slow-down in gas production is the cue that there is a problem with digester. Engine oil changes are performed every 450 hours on average, using a high ash oil developed for natural gas engines. The engines selected for project were expensive, but provide a $95-96 \%$ avallability factor including engine overhauls. Has had 30,000 to 40,000 hours between engine overhauls, although 15,000 to 20,000 hours is normal. The fact that slightly oversized engines were installed, combined with the type of engine oil and frequency of oil changes, may be the reason for relatively long time between overhauls. Biogas cleaning is done by a chemical filter system which should be changed every 2,000 hours. Filters have not been maintained, with no detected difference in engine performance.

Would essentially do the same thing, but would install a heavier cover. Sharp Energy is patenting a modular cover which will both act as an insulator and help drain-off rain and snow. Would use better quality equipment even if it costs more on the front-end, because over the life-cycle of system the investment will pay out. This was found to be especially true on the Caruthers Ranch project where a less-expensive engine was destroyed by hydrogen sulfide which corroded copper and bronze fittings. To the extent possible use aluminum fittings.
COSTING INFORMATION

Siting Cost:

Capital Cost:

Annual O\&M Cost:

End-Use of Biogas:

Prime Mover Type:
Not available.

$\$ 89,000$ for initial project. Project expansion unavailable.

Not available.

Electricity production with hot air reclaim used for supplemental heating in nursery barns.

75-kW Waukesha induction generator modified by Perennial Energy initially installed. 100-kW Waukesha installed during project expansion.
ANNUAL SAVINGS

Electricity Production:

Electricity Offsets:

Thermal Production:

Thermal Offsets:

End-Uses of Effluent:

INITIAL DESIGNER:
700,000 to $750,000 \mathrm{kWh}$.

$\$ 43,000$ to $\$ 44,000$ in offset power bills and in excess generation sales at $\$ 0.026$ avoided cost rate.

Not available.

$\$ 5,000$.

Effluent recycled from third lagoon is used for parlor flushing and the excess is irrigated.

Jeff Chandler.

SYSTEM INSTALLER: 
CASE STUDY 48 . ARRONA AAIRY COMPANY ?: : :

\begin{tabular}{ll|}
\hline CONTACTS & David Acedo \\
\hline Address: & Arizona Dairy Company \\
& 19135 East Elliott Highway \\
& Higley, AZ 85236
\end{tabular}

Telephone: $\quad 6028335834$

GENERAL SYSTEMINFORMATION

Herd Type: Dairy.

Herd Size:

15,000 total head with 5,000 milkers.

System Types:

Three (3) plug flow units with Pervalon cover material.

Dimensions:

Plug 1: 144 feet $\times 56$ feet $\times 20$ feet.

Plug 2: 167 feet $\times 56$ feet $\times 20$ feet.

Plug 3: 165 feet $\times 56$ feet $\times 20$ feet.

Capacity:

Plug 1: 161,000 cubic feet (1.2 million gallons).

Plug 2: 187,000 cubic feet (1.4 million gallons).

Plug 3: 185,000 cubic feet ( 1.4 million gallons).

Gas Production:

Never metered. Based on the amount of electricity generated, biogas production is probably between 115 and 120 thousand cubic feet per day $160 \%$ methane content).

Operational Date: 1983.

Estimated Life: 20 years.

Current Status: Operational.

Project History: $\quad$ Owner wanted to be innovative and also to save money by converting a waste problem into a resource. The three digesters are run in a serial arrangement, and use the wastes from only about 1500-2000 milkers. Because the farm is operated under a time-of-day rate, the biogas is compressed to fuel the engine/generator only during the TOD schedule.

Maintenance History:

This very large farm requires a full-time person to move the manure from the various scraped collection areas to the digesters. Once at the input digester, wastes are mixed to the desired concentration level and are pumped sequentially between the three digesters. Basic daily maintenance includes checking the cover and biogas lines for leakage. The water catches between the digesters, and the biogas water trap filter system used for hydrogen sulfide scrubbing is drained daily. Engine oil is checked before start up, and the engines are monitored during operation to make sure they are running correctly. Engine oil is changed every 400 hours using a special oil designed for natural gas engines. The engine has been rebuilt three times since 1983, with the last overhaul occurring two years ago. The digester pits are cleaned out to remove solids at the time the cover material is replaced, which is necessary about every three years. 
Lessons Learned:

Would like to develop a system that uses the wastes from all the herd's milkers, as well as one that increases co-product utilization. Found that better overall performance is achieved by keeping the digester operating even when the engine is not running. Consequently, the digesters are heated with an auxiliary propane gas boiler. Monitors digester temperatures: desired temperature range is between $97-100$ degrees (F). Found also that biogas production increases when the manure is agitated to help keep solids in suspension. Current practice is to try to get the manure into a good slurry before input into the first digester and as the wastes are transferred between digesters. Thinks that a better method to keep the solids suspended would help reduce crusting. Not only do solids reduce the volume of biogas produced, they destroy manure pumps. Would like to devise a wash system to move manure directly into digester, especially at the feed lanes. The feed lanes are now scraped every other day, and if the digesters were set up to receive fresher manures, the system could increase biogas production by 25 percent. Formerly ran two air-cooled compressors in a serial arrangement for biogas storage. The compressors' high operating temperatures were transferred to the biogas which reduced overall biogas storage potentials. Air-cooled compressors operating at high temperatures also fail frequently. Installed a spare water-cooled compressor--a Nash vacuum pump-- and eliminated the two air-cooled units. Since changing the compressor system (1993), has had no maintenance problems, and the water cooling also helps to provide additional biogas scrubbing.

COSTING INFORMATION

Siting Cost:

Capital Cost:

Annual O\&M Cost:

End-Use of Biogas:

Prime Mover Type:
Not available.

$\$ 300,000$ for the initial system installed in 1983 .

Not available, but estimated to be $\$ 12,000$ to $\$ 15,000$ for materials and equipment. The labor cost is one full-time equivalent position.

Electricity production with no thermal reclaim.

One 500-kW model G-398 Caterpillar natural gas engine-generator.
ANNUAL SAVINGS

Electricity Production:

Electricity Offsets:

Thermal Production:

Thermal Offsets:

End-Uses of Effluent:

DESIGNER:

INSTALLER:
Estimated between 1.3 and 1.7 million $\mathrm{kWh}$, with the engine/generator operating between 8 to 10 hours daily.

Estimated between $\$ 125,000$ and $\$ 160,000$. $\$ 0.098$ is the current peak $\mathrm{kWh}$ charge, with no demand charge. Off-peak rate is $\$ 0.04$.

Not applicable.

Not applicable.

Liquids are spray irrigated onto croplands. Solids are land applied.

Don Sherman (Cornell University).

Not available. 


\section{CASE STUDY 49:}

\begin{tabular}{|ll|}
\hline CONTACTS & Darrell Smith \\
\hline Address: & Darrell Smith Farm \\
& Route 2, Box 45 \\
& Princeton, NC 27569
\end{tabular}

Telephone: $\quad 9197346107$

\section{GENERAL SYSTEM INFORMATION}

Herd Type: Poultry.

Herd Size:

System Type:

Dimensions:

Capacity:

Gas Production:

Operational Date:

Estimated Life:

Current Status:

Project History:

Maintenance History:
70,000 caged layer hens.

Mixed metal tank primary.

Partial covered lagoon with XR-5 cover material secondary.

28 foot $x 31$ foot diameter primary.

50 foot $\times 80$ foot secondary.

21,000 cubic feet working volume $\left(158,000\right.$ gallons) primary ${ }^{1}$.

17,000 cubic feet per day primary initially $(58 \% \text { methane content })^{1}$

21,000 cubic feet per day primary currently $(62 \% \text { methane content })^{2}$

2,100 average cubic feet per day secondary $(65 \% \text { methane content })^{3}$.

1983 primary.

1985 secondary.

20 years primary.

10 years secondary.

Operational.

The project was initiated to control odor and because of other environmental concerns. Because a $\$ 0.11$ per $\mathrm{kWh}$ electrical buy-back rate was offered by the local power company when the project began operating, the initial operating strategy was to store the biogas and generate electricity for sale at peak demand periods. New utility power units have come on-line since then, and the operating strategy now is to provide for load displacement. The floating cover was added in 1985 as part of a continuing research project conducted by NC State University with funds provided by the USDOE's Southeast Regional Biomass Energy Program. About 25 percent of the lagoon is covered in the area where hot effluent is discharged from the primary mixed tank digester. No modifications, such as increasing its depth of the lagoon, were made when the cover was installed. The additional biogas harvested from the lagoon increased the total biogas production at the site by 5 to 15 percent, depending on the time of year.

About one hour per day is spent monitoring digester. The digester is fed a seven percent solids content every two hours, with a total of 
Lessons Learned:

6,355 gallons of poultry manure added per day. There have been a number of engine/generator problems reported, primarily related to the undersizing of the cooling system. A faulty casting also cracked the engine head. The generator control panel was replaced because of corrosion caused by hydrogen sulfide. Additional maintenance was needed because of grit buildup on the primary tank's bottom.

"One of the major problems encountered...has been the grit in the manure...At manure solids contents less than 8-9 percent TS, the grit will settle in a short time. Accumulation of this material necessitated the cleaning of the digester on two occasions [in four years of operation]. To reduce the amount of grit reaching the digester, a strategy of mixing the manure, letting the grit settle (2-10 minutes) and pumping the supernatant to an adjacent pit was developed. The degritted manure was then fed to the digester as needed...[T]ests determined that such a...procedure could reduce the fixed solids...by $55 \%$. Of the remaining fixed-solid material approximately $33 \%$ or more is estimated to pass through the digester." 1

COSTING INFORMATION

Siting Cost: Not available.

Capital Cost: $\$ 225,000$ for primary system. $\$ 25,000$ for the secondary system, but this includes additional incidental costs due to nature of project.

Annual O\&M Cost:

$\$ 4,750$ to $\$ 5,860$.

End-Use of Biogas:

Electricity with thermal reclaim used for heating digester.

Prime Mover Type:

80-kW Minneapolis-Moline.
ANNUAL SAVINGS

Electricity Production:

Electricity Offsets:

Thermal Production/Offsets: Not applicable.

End-Uses of Effluent:

Landspread from lagoon, some waste is re-fed into digester.

TANK SYSTEM DESIGNERS: Bio-Gas of Colorado and A.O. Smith Harvestore.

TANK SYSTEM INSTALLER: A.O. Smith Harvestore

1. Safley, Vetter and Smith (1987) Operating a Full-Scale Poultry Manure Digester. Biological Wastes 19:79-90. 2. Vetter, R. pers. communication, 30 November 1994.

3. Safley and Westerman (1989) Anaerobic Lagoon Biogas Recovery Systems. Biological Wastes 27:43-62.

$300,000 \mathrm{kWh}$ with original on-peak operating strategy.

$\$ 26,000$. $\$ 0.05$ is the current on-peak $\mathrm{kWh}$ charge, with no demand charge. 


\section{CASESTUDY 410 . OREGONDAIRY FARMS}

\begin{tabular}{ll}
\hline CONTACTS & George \& Mary Hurst \\
\hline Address: & Oregon Dairy Farms \\
& 2870 Oregon Pike \\
& Lititz, PA 17543
\end{tabular}

Telephone:

7176567305

\section{GENERAL SYSTEM INFORMATION}

Herd Type:

Dairy.

Herd Size:

300 total head with 250 milkers.

System Type:

Slurry-based loop with Hypalon cover material.

Dimensions:

40 foot diameter $\times 12$ foot deep.

Capacity:

15,000 cubic feet $(112,000$ gallons $)$.

Gas Production:

Never metered.

Operational Date:

1983.

Estimated Life:

10 years?

Current Status:

Operational.

Project History:

The project was initiated as a result of concerns about future energy costs. Additional encouragement was provided by the local electric utility's need for capacity and by the 10 percent federal energy tax credit which was in place before the Tax Reform Act of 1986. An additional reason for implementation was odor control.

Maintenance History:

No major problems reported. Performs a 15 minute daily walk through inspection, mainly checking engine oil, manure pumps, and monitoring waste flow. Performed a major engine overhaul (down to bearings) in 1988. Formerly used an iron sponge to strip hydrogen sulfide from biogas, but hydrogen sulfides are no longer a significant problem due to frequent oil changes. Replaced heat exchanger because factory-built unit did not perform to specification. The black iron hot water pipe running to the house lasted only two years, and was replaced with a high-temperature plastic pipe. Changed side walls of digester building from steel to vinyl because of hydrogen sulfide corrosion.

Lessons Learned:

Would try to reduce first cost, but unsure of exact measures required. Although project did not produce its estimated 10 year simple payback from energy offsets alone, would do it again because of intangible benefits. Feels that only farms with 200 to 300 head and larger should consider implementing given present capital costs. 
COSTING INFORMATION

Siting Cost: Included in turn-key price.

Capital Cost:

$\$ 120,000$ turn key.

Annual O\&M Cost:

$\$ 3,500$ to $\$ 4,000 \quad(\$ 2,500$ on oil and filters and $\$ 1,000$ on the annualized cost of 5 year major rebuild of engine).

End-Use of Biogas:

Electricity with thermal reclaim used for home heating.

Prime Mover Type:

50-kW model g333 Caterpillar gasoline engine which was modified by advancing timing 30 degrees to operate on a dual-fuel basis for load displacement. Occasionally supplements biogas with propane when needed.

ANNUAL SAVINGS

Electricity Production:

Electricity Offsets:

Thermal Production:

Thermal Offsets:

End-Uses of Effluent:

Other System Savings:

SYSTEM DESIGNER:

SYSTEM INSTALLER:
200,000 to $250,000 \mathrm{kWh}$ annually.

Estimated between $\$ 12,000$ and $\$ 15,000$. $\$ 0.06$ is the current $\mathrm{kWh}$ energy charge, with no demand charge.

Not available.

$\$ 1,200$ annually on home heating.

Digested manure pumped to lagoon and land applied. Formerly sold separated solids, but quit selling because market was saturated.

Easier manure management because of the slurry's more homogenous consistency. Unsure of specific nutrient value of digested manure, but does not have to add chemical fertilizers to effluent-applied lands. Also because manure is less acidic ( $\mathrm{pH}$ changes from 6.3 to 7.1 as a result of the digestion process), has to add less lime to soil.

Used basic loop digester design of Mason Dixon Farms, then added or deleted functions and parts according to their own needs.

Oregon Dairy Farms. 
CASE STUDY $4.1 \%$ GRANTAMENDAIRY

\begin{tabular}{lll|}
\hline CONTACTS & Grant Amen & Kelly Durgan \\
\hline Address: & Grant Amen Dairy & Grant Amen Dairy \\
& 2305 Duncan Lane & 2305 Duncan Lane \\
& Redding, CA 96002 & Redding, CA 96002
\end{tabular}

Telephone:

9162213481

9162213481

\section{GENERAL SYSTEM INFORMATION}

Herd Type: Dairy.

Herd Size:

750 total head with 420 milkers.

System Type:

Mixed metal tank.

Dimensions:

28 foot $\times 30$ foot diameter.

Capacity:

18,700 cubic feet $(140,000 \text { gallons })^{\top}$.

Gas Production:

29,000 cubic feet per day'.

Operational Date:

1984.

Estimated Life:

$15-20$ years.

Current Status:

Operational.

Project History:

Maintenance History:

Project installed with $50 \%$ state funding. There was an interest in reducing energy bills by converting biogas into electrical power.

Because of competing demands on farm labor, digester preventive maintenance has been lacking. This has resulted in extended "temporary" shut down periods. The digester is presently being brought back on-line after an extended outage following the removal of built-up solids and general tank cleaning. Foaming, reported to be a problem in the literature, was not a great factor. The parlor hot water system has not worked well due to poor plumbing and an engine/generator heat exchanger that is not functioning properly. Digested solids are separated with a perforated slide; this aging equipment has proven difficult to keep in operation. Normal amount of pump repair required, as can be expected from a scrape manure management system. Engine/generator oil changed every 2000 to 3000 hours.

Lessons Learned:

The complete mix digester has been somewhat difficult to operate and maintain, and has required farm engineering to solve problems. Should have been focused on hot water plumbing details to enable the capture of hot water from the engine/generator heat exchanger. Some general satisfaction, but complexity of mixed tank digester operation is beyond normal level of farm interest:. Would consider converting from scrape 
to a hydraulic flush manure management system and use a covered lagoon digester, if had to do it all over again.

COSTING INFORMATION

Siting Cost: Not available.

Capital Cost:

$\$ 185,000^{1}$.

Annual O\&M Cost:

End-Use of Biogas:

Prime Mover Type:
$\$ 7,500$ reported', however given the recent problems encountered annual $O \& M$ could be as high as $\$ 12,000$.

Electricity with thermal reclaim used for digester heating. As noted above, opportunity to utilize waste heat from the engine/generator for milking parlor hot water was lost because of plumbing details.

65-kW model 504A (turbo) Minneapolis-Moline modified by Perennial Energy.
ANNUAL SAVINGS

Electricity Production:

Electricity Offsets:

Thermal Production:

Thermal Offsets:

End-Uses of Effiluent:

Other System Savings:

SYSTEM DESIGNER:

SYSTEM INSTALLER:
375,000 to $400,000 \mathrm{kWh}$.

Estimated' at $\$ 26,000$ with an energy cost of $\$ 0.07$ per $k W h$.

Not applicable.

Not applicable.

The discharged effluent is separated into solid and liquid fractions. The liquids are pumped to a lagoon for land application. De-watered solids are composted and sold locally.

$\$ 12,000$ from sale of solids.

Jeff Chandler.

Bio-Gas of Colorado.

1. Ashworth, J. (1985) Universe of US Commercial-Scale Anaerobic Digesters: Results of SERI/ARD Data Collection. Prepared by Associates in Rural Development for the Solar Energy Research Institute. 


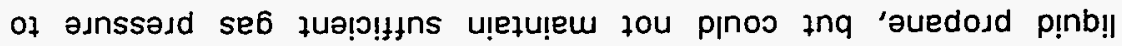

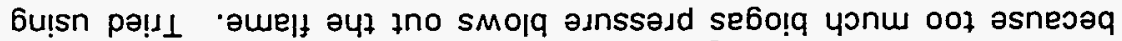

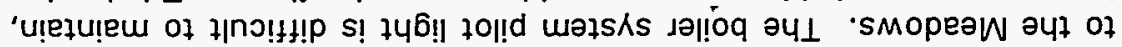

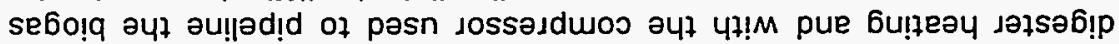

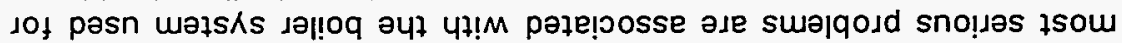

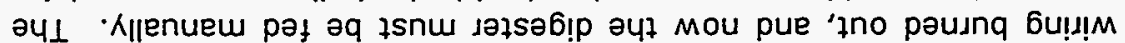

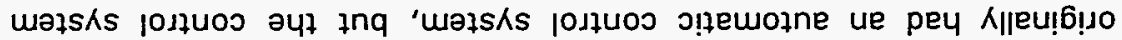
məłs

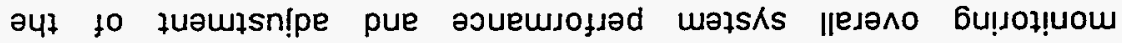

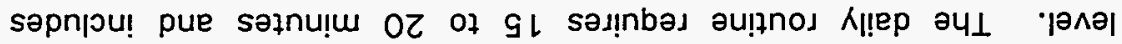

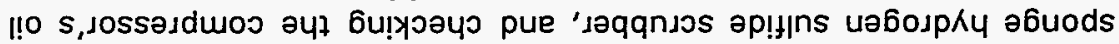

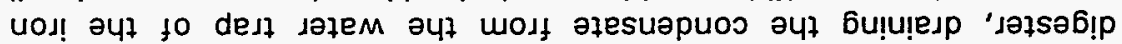

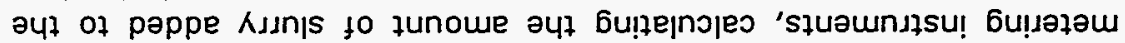

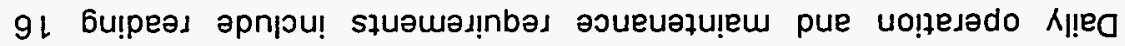

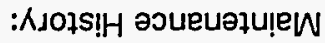

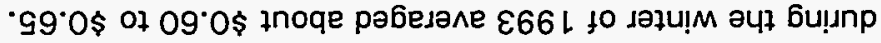

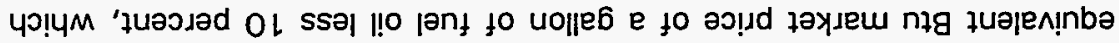
ue fe smopeəw aut of plos s! sebo!̣ sebo!̣ uo әfejədo of sjə!loq

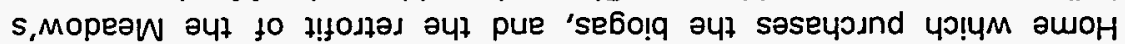

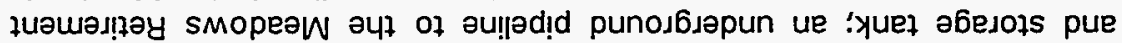

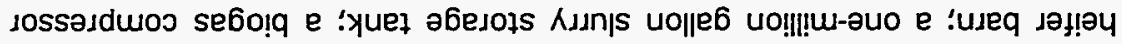

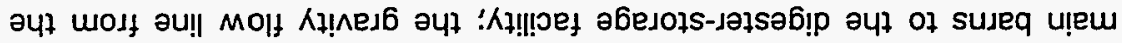

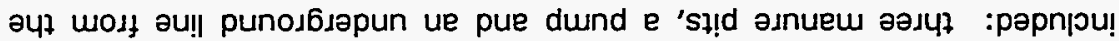

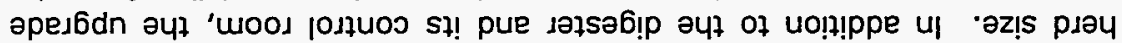

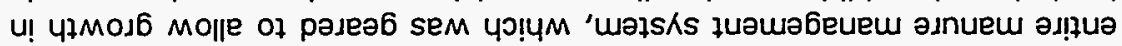

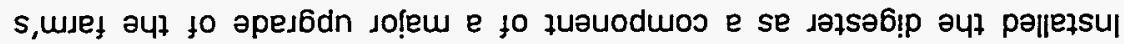

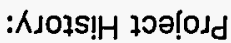

•jeuoịejedo

:sniets quajuno

-sieak OZ

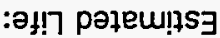

9861

:әjeg jeuo!̣ejado

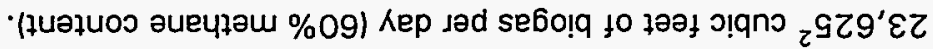

:uo!̣onposd seg

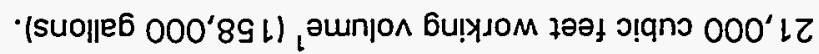

:রi!oedeว

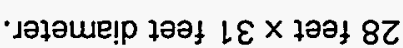

:suo!̣suəu!̣

•Yuez pax!W

$: \partial d \Lambda_{\perp}$ wəIshs

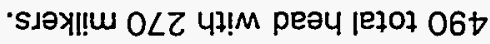

:əz!S PJəH

- Nu!eg

$: ə \mathrm{dK} \perp \mathrm{pJ} \mathrm{pH}_{\mathrm{H}}$

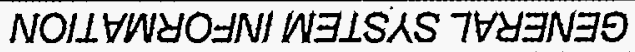

$\varepsilon 909 \angle t 9 \angle 09$

:əuoudəןə】

9てEEL NN 'UMOISJədoOJ

$827 \times 09$ ‘ $\triangleright$ yy

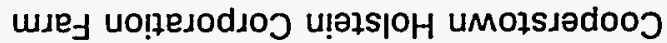
:ssojpp $\forall$

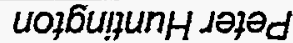
$S \perp O \forall \perp N O O$

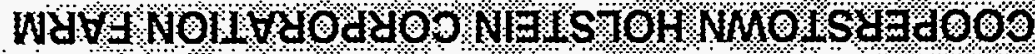

21 t kanLs asyo 
Lessons Learned:

sustain pilot flame. The compressor unit has been rebuilt twice at a cost of $\$ 6,000$ per rebuild. The original unit was of poor design, which led to bearing failure. Has had to install a new compressor and tank system to move the biogas through the pipeline to the Meadows. The circulation pump has had its bearings rebuilt twice. The slurry chopper pump used to keep solids in suspension has been rebuilt four times in the past eight years. After operating less than one year, the failure of the solids separator in 1987 led to the decision not to collect solids for use as bedding. The longest period that the digester has been down was caused by a three-day cleaning to remove built-up solids in 1988 .

The digester's manual feeding system has reduced biogas production by 25 to 30 percent, and "adequate documentation on the wiring panels would have prevented this problem ${ }^{1}$." The automatic operation of the digester's feeding system was restored by an electrical contractor during September 1994. At the time the digester was down in 1988, the return flow of the slurry was repositioned by moving a mixing pump from the center of the digester to the wall. This was done to reduce thermal bridging impacts caused by built-up solids. . Will install a 40- to $50-\mathrm{kW}$ engine/generator with the next compressor failure to eliminate boiler and compressor problems.

COSTING INFORMATION

Siting Cost: Included in capital cost.

Capital Cost:

$\$ 500,000$ for entire manure handling improvement operation.

Annual O\&M Cost:

Estimated to be $\$ 4,125$ plus labor expenses ${ }^{\prime}$.

End-Use of Biogas:

Thermal production for digester heating and pipelined to the Meadows for water and space heating.

Prime Mover Type: Not applicable.

ANNUAL SAVINGS

Energy Production:

Energy Offsets:

Thermal Production:

Thermal Offsets:

End-Uses of Effluent:

Other System Savings:

DESIGNER/INSTALLER:
17,000 to 18,000 gallons of fuel oil equivalent sold to the Meadows.

Estimated at $\$ 10,600$ at the 1993 price of fuel oil.

About one-third of the biogas generated is used for digester heating.

Not applicable.

Digester effluent is stored in slurry tank for later land-application on corn. Effluent fertilizer value is estimated to be $\$ 25,000$ per year.

Would do an anaerobic digestion project solely for odor control.

A. O. Smith Harvestore.

1. Koelsch, et al. (1989) Experience with Three Anaerobic Digestion Systems on Commercial Dairies. American Society of Agricultural Engineers Paper No. 89-6550. 17 pages.

2. Vetter, et al. (1990) Full Scale Anaerobic Digester and Waste Management System for a 300 Cow Dairy. Proceedings of the Sixth International Symposium on Agricultural and Food Processing Wastes. P. 236-49. 
Lessons Learned:

131 degrees F). Although the original $60-\mathrm{kW}$ engine/generator is still installed, it is not being used because of the inconvenience of its relatively small electrical capacity. The M\&M facility now uses a new dual-fueled boiler because of digester temperature requirements and the lack of digester insulation.

Zero discharge of effluents is the company goal. They wish to transform digested solids and liquids into the most valuable product, and thereby offer an economically attractive recycling solution to the disposal of animal manures.

COSTING INFORMATION

Siting Cost: Not available.

Capital Cost:

Not available, but a considerable amount was spent on digester reconfiguration and the on-site research facility than would be required for a commercial facility.

Annual O\&M Cost: Not available.

End-Use of Biogas: Process heat used for heating digester.

Prime Mover Type: $\quad$ Not available.

ANNUAL SAVINGS

Electricity Production: Not applicable.

Electricity Offsets: $\quad$ Not applicable.

Thermal Production: Not applicable.

Thermal Offsets: $\quad$ Not applicable.

End Uses of Effluent: $\quad$ After leaving the digester, the fermented slurry is separated into liquid and solid fractions. The solid fraction is called NutriTex after additional thermophilic aerobic processing. It is sold as a replacement for highgrade peat moss, and can also be used for mulching and as a superabsorbant. The liquid fraction (NutriPlus) is used as a fertilizer. Field tests have shown that it provides a wide spectrum of microflora, fine organic matter, and hormone-like substances leading to superior plant growth because of its benefit to rootstock development. A third product, AlTex, is a range of custom-blended potting soil components that is produced by processing NutriPlus with locally available organic wastes. AlTex is formulated to fulfill specialized needs of potting soil.

Other System Savings:

BTI believes they integrate the most efficient processes into their systems. These processes include high-rate thermophilic anaerobic digestion, special separation techniques, and controlled aerobic digestion that results in the optimal added-value for each product.

SYSTEM DESIGNER: $\quad$ BioRecycling Technologies, Inc.

SYSTEM INSTALLER: BioRecycling Technologies, Inc. 


\title{
CASE STUDY 4.14 . ROOKY KMOUL FARMS
}

\begin{tabular}{ll|}
\hline CONTACTS & Harlan Keener: \\
\hline Address: & Rocky Knoll Farms \\
& 1266 Gypsy Hill Road \\
& Lancaster, PA 17602
\end{tabular}

Telephone:

7174642669

\begin{abstract}
GENERAL SYSTEM INFORMATION
Herd Type: Swine (farrow-to-finish).

Herd Size:

13,000 total head with 1,000 sows.

System Type:

Modified plug flow (a side-mounted pump agitates liquid in digester on a periodic basis to reduce crusting) with $X R-5$ cover material.

Dimensions:

28 feet $\times 143$ feet $\times 14$ feet (deepest point).

Capacity:

46,800 cubic feet $(350,000$ gallons $)$.

Gas Production:

60,000 cubic feet of biogas per day $(60-62 \%$ methane content).

Operational Date:

1985.

Estimated Life:

10-15 years, but digester cover was recently replaced.

Current Status:

Operational.

Project History:

Project initiated because of desire to proactively reduce risk of odor complaints by neighbors.

Maintenance History:

Spends an average of 15 to 30 minutes a day checking engine oil levels and other system components. Performs frequent oil changes on engine/generator (every 360 hours). Formerly used an iron sponge to strip hydrogen sulfide from biogas, but hydrogen sulfides are no longer a significant problem due to frequent engine oil changes. Keeps digester at 100 degrees $(F)$ using waste heat discharged from engine. Has never had to pump out digester because of the low lignin content of the manure.
\end{abstract}

Lessons Learned:

"Mistakes are what you call experience." Original building housing the digester was destroyed because of hydrogen sulfide emissions and replaced by a building with an open ridge vent to allow any collected gases to dissipate. Would move digester further from other farm buildings to avoid contamination from engine exhaust gas discharge. Had leaks in pipes caused by electrolysis. Leaks were mitigated by installing zinc bars for cathodic protection. Would use building materials that do not corrode like aluminum. Would try to use surplus materials to reduce first-cost. Would factor in a greater emphasis on gravity flow of manure. 
COSTING INFORMATION

Siting Cost:

Capital Cost:

Annual O\&M Cost:

End-Use of Biogas:

Prime Mover Type:
Included in turn-key contract.

$\$ 225,000+\$ 100,000$ for modifications.

$\$ 8,000$.

Electricity production with thermal reciaim. Farrowing rooms and nursery have heating requirements partially supplemented from hot water reclaimed from engine/generator. Also uses hot water at 150 degrees (F) for high-pressure wash down.

200-kW model 342 Caterpillar natural gas engine-generator which generally operates with a load displacement of $125-\mathrm{kW}$. Has secondary $25-\mathrm{kW}$ Kohler which runs during period of excess biogas production.
ANNUAL SAVINGS

Electricity Production:

Electricity Offsets:

Thermal Production:

Thermal Offsets:

End-Uses of Effluent:

Other System Savings:

SYSTEM DESIGNER:

SYSTEM INSTALLER:
1.0 to 1.2 million $\mathrm{kWh}$.

Estimated between $\$ 60,000$ to $\$ 65,000$. $\$ 0.06$ is the current $\mathrm{kWh}$ charge, with no demand charge.

Estimated equivalent of 12 gallons of propane per hour $(1.1$ million Btu per hour).

$\$ 40,000$ for heating season (September through April) at $\$ 0.60$ per gallon of propane.

Landspread on crops for nutrient value with a displaced fertilizer value of $\$ 15,000$ annually for the 250 acres that receive the effluent.

No money spent on legal defense for odor complaints. Eases manure handling requirements and permits simpler application of nutrients when land-applied.

Energy Cycle, Inc.

Energy Cycle, Inc. 
Lessons Learned:

is going to be a high maintenance item, because even storage tanks require pumping."

Digester has some foaming problems and crusted solids built-up at the top. Has recently installed a 25 percent larger heat exchanger to increase biogas production during cold weather, and will be able to document biogas production rates this winter (1994). Also would revise manure collection pit so that it could be agitated periodically. Additional agitation with a mixer in the digester could make the process more efficient, "but what is the benefit-to-cost of doing so?"

COSTING INFORMATION

Siting Cost:

Included in capital cost.

Capital Cost:

$\$ 250,000$.

Annual O\&M Cost:

Not available, but estimated at $\$ 5,000$.

End-Use of Biogas:

Electricity with thermal reclaim. Farrowing rooms and nursery heating system use 20 Modine heaters. Recovers hot water from engine/generator for high-pressure wash down. Heating oil boiler used for supplemental backup.

Prime Mover Type:

110-kW model 3306 Caterpillar engine/generator which generally operates with a load displacement of $100-$ to $130 \mathrm{~kW}$. Has secondary 40-kW Chrysler back-up engine that also operates during periods of excess biogas production.

ANNUAL SAVINGS

Electricity Production:

Estimated between 775 to 850 thousand $\mathrm{kWh}$.

Electricity Offsets:

Thermal Production:

Not available.

Thermal Costs/Offsets:

Estimated at $\$ 15,000$ for the heating season.

End-Uses of Effluent:

Liquids first go to slurry tanks, and are later land-applied onto croplands producing corn, wheat, and soybeans.

Other System Savings:

The fertilizer value of swine waste does not change as a result of the anaerobic digestion process, and Valley Pork is more comfortable using digested slurry than traditional fertilizers. Not much difference in the volumes of solids that build up in the three slurry tanks.

DESIGNER:

Resource Conservation Management, Inc.

INSTALLER:

Hershey Equipment. 


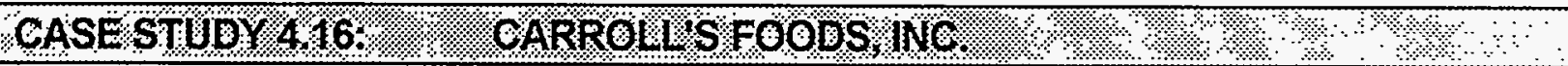

\begin{tabular}{ll}
\hline CONTACTS & Bob McLeod \\
\hline Address: & Carroll's Foods, Inc. \\
& Post Office Box 856 \\
& Warsaw, NC 28398
\end{tabular}

Telephone:

9192933434

\section{GENERAL SYSTEM INFORMATION}

Herd Type:

Herd Size:

System Type:

Dimensions:

Capacity:

Gas Production:

Operational Date:

Estimated Life:

Current Status:

Project History:

Maintenance History:
Swine (farrow-to-finish).

11,500 total head with 1,000 sows.

Covered lagoon with XR-5 material.

265 feet $\times 265$ feet on surface $\times 24$ feet deep. $147 \times 147$ @ 24 feet with a 2.5:1 sideslope.

935,400 cubic feet ( 7 million gallons).

70,000 cubic feet of biogas per day predicted (65\% methane content).

29,000 cubic feet of biogas per day initial production $180 \%$ methane content).

Cover installed August 1992.

Prime mover to be installed late 1994.

15 years.

Operational with respect to biogas collection.

The North Carolina Energy Division and North Carolina State University first constructed a covered lagoon digester at the Randleigh Dairy in 1987 using funds provided by the USDOE's Southeastern Regional Biomass Energy Program, the NC Agricultural Research Service, and the NC Dairy Foundation. The Division's swine digester demonstration project is a substantial scale-up of the Randleigh site. The project objective is to inform swine integrators and producers through practical demonstration and educational outreach about the merits of a lower-cost and more easily maintained digester suitable for use on farms using hydraulic flush manure management systems. Carroll's Foods was selected as the host cooperator following a Request for Qualifications process. Although the cover has been installed and collecting biogas for two years, the project has been delayed because of institutional problems with the facility's electric supplier.

Minor start-up problems, but nothing requiring major maintenance. Metering problems from particles wedged in the gas meter precluded measuring gas production. Three minor holes in cover, but patching was not a problem since the cover was new. 
Lessons Learned:

Lift station would be designed differently, because there is no need to keep solids in suspension. Would make lift station sump smaller as a result. Original cover attachment was earth-bermed, but did not seal because of dirt in trench. Had to mechanically seal edges of cover to attachment apron.

COSTING INFORMATION

Siting Cost:

Capital Cost:

Annual O\&M Cost:

End-Use of Biogas:

Prime Mover Type:

ANNUAL SAVINGS

Electricity Production:

Electricity Offsets:

Thermal Production:

Thermal Offsets:

End-Uses of Effluent:

Other System Savings:

SYSTEM DESIGNER:

SYSTEM INSTALLER:

OTHER CONTACTS:

Company:

Address:

Telephone:

Fax:
$\$ 88,000$ (includes costs additional to siting due to nature of project).

$\$ 191,500$ (42 percent Carroll's cost-share).

$\$ 8,000$ to $\$ 10,000$ projected when engine/generator installed.

Electricity production with thermal reclaim to be used for digester heating.

To be determined, $110-\mathrm{kW}$ is target size.

820 thousand $\mathrm{kWh}$ with an 85 percent availability factor.

Not available. $\$ 0.06$ is the current $\mathrm{kWh}$ charge, with a $\$ 12.00$ demand charge.

Not applicable.

Not applicable.

Land application from a second cell.

None that can be cited to date, but some savings could result from a reduction in excess nitrogen disposal.

AgriWaste Technology, Inc.

Carroll's Foods of North Carolina.

Tim Butler

North Carolina Energy Division

430 N. Salisbury Street

Raleigh, NC 27611

9197332230

9197332953 
GASE STUDY $4.17 \%$ LOUPAUMER FARM : $: \%: \%$

\begin{tabular}{ll|}
\hline CONTACTS & Jim Wimberly \\
\hline Address: & Winrock International \\
& Petit Jean Mountain \\
& Morrilton, AR 72110-9537
\end{tabular}

Telephone: $\quad 5017275435$

GENERAL SYSTEM INFORMATION

Herd Type: Swine (farrow-to-feed)

Herd Size:

3,500 total head with 300 sows.

System Type:

Covered lagoon with internal drainage, testing two lower-cost cover materials: polyflex (HDPE family) and coolguard (XR-5 family).

Dimensions:

40 feet $\times 110$ feet $\times 8$ feet.

Capacity:

35,200 cubic feet $(263,000$ gallons $)$.

Gas Production:

3,200 cubic feet of biogas per day in summer ( $80 \%$ methane content). 1,400 cubic feet of biogas per day in winter ( $80 \%$ methane content).

Operational Date:

1992.

Estimated Life:

Unknown, due to nature of cover materials.

Current Status:

Operational with respect to biogas collection.

Project History:

Project initiated to measure technical and economic feasibility of covering existing lagoons on smaller-scale (marginal) systems. Project was sponsored by the Southeastern Regional Biomass Energy Program.

Maintenance History: Little time spent on maintenance on a daily basis. A biogas meter was gummed up. Some gas pipes have been plugged when the biogas pump sucked solids into the transfer pipes. A dead bird clogged a biogas flare pipe.

Lessons Learned:

Appears to be an adequate, less expensive design for covering existing lagoons at small facilities with no modifications required to their waste lagoon configurations. Biogas handling system has been modified on intake side to reduce chance of plugging.

COSTING INFORMATION

Siting Cost: Included in turn-key contract.

Capital Cost: $\quad \$ 16,000(\$ 10,450$ for materials with balance for system design and installation labor).

Annual O\&M Cost: $\quad$ Estimated at less than $\$ 500$, but project not on-line long enough to fully document. 
End-Use of Biogas: $\quad$ Currently flared, pending final utilization decision. Will probably be used for space heating in winter.

Prime Mover Type: $\quad$ Modified cast iron wood stove heater, with conventional propane-fired hot air heaters used as backup.

ANNUAL SAVINGS

Electricity Production:

Not applicable.

Electricity Offsets:

Not applicable.

Thermal Production:

Equivalent of $12-13$ gallons of propane per day (1.12 million Btu per day).

Thermal Offsets:

Estimated at $\$ 2,500$ for heating season (September through April) with propane costing $\$ 0.85$ per gallon.

End-Uses of Effluent:

Landspread on crops for nutrient value. Some water is recycled from a second cell of the lagoon system and used for hydraulic flushing.

Other System Savings:

None.

SYSTEM DESIGNER

Resource Conservation Management, Inc.

SYSTEM INSTALLER:

Resource Conservation Management, Inc.

OTHER CONTACTS:

Joe Gentry

Company:

Arkansas Science and Technology Authority

Address:

100 Main Street, Suite 450

Little Rock, AR 72201

Telephone:

5013249006

Fax:

5013249012 


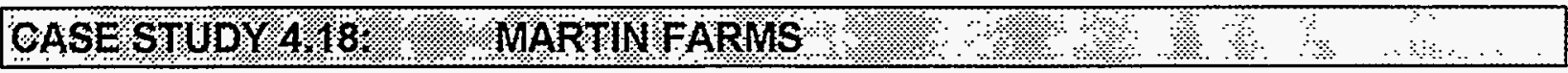

\begin{tabular}{lll|}
\hline CONTACTS & Debbie \& Harold Martin & Stacy Gettier \& Mike Roberts \\
\hline Address: & Martin Farms & Carroll's Food of Virginia \\
& Rt. 1 Box 310 & P.O. Box 1240 \\
& South Boston, VA 24592 & Waverly, VA 23890
\end{tabular}

Telephone: $\quad 8044766613$ (barn) $\quad 8048342109$

GENERAL SYSTEM INFORMATION

Herd Type: Swine (farrow-to-feeder).

Herd Size:

3,000 total head with 600 sows.

System Type:

Covered lagoon with XR-5 cover material.

Dimensions:

120 feet $\times 120$ feet $\times 27$ feet.

Capacity:

389,000 cubic feet (2.9 million gallons).

Gas Production:

11,780 cubic feet of biogas per day average $\left(70 \%\right.$ methane content) ${ }^{1}$.

Operational Date:

Cover installed 1993, prime mover operational March 1994.

Estimated Life:

20 years.

Current Status:

Operational.

Project History:

Martin Farms, Carroll's Foods of Virginia, the Virginia Department of Mines, Minerals and Energy, and USDOE's Southeast Regional Biomass Energy Program collaboratively funded this demonstration project. The project is the first of its kind in Virginia and believed to be the first farm in the nation designed to incorporate an anaerobic digester from its inception in 1992. On average, a little over $80 \%$ of the farm's electrical energy needs are provided. Due to the nature of the system, it is expected that electrical generation during the winter will average $12-$ to $15-\mathrm{kW}$. During the summer, electrical generation is expected to exceed $25-\mathrm{kW}$. It is not anticipated that the project will produce more electricity than the Martin's farm will consume. The farm waste management system is based on hydraulic flushing and features two cells: the passive covered digester and a second storage lagoon. A heat exchange grid was installed on the bottom of the digester to act as the engine's radiator, and to use the waste heat to warm the lagoon during the winter. A warmer lagoon will increase biogas production during the cooler months and help reduce sludge accumulation.

Maintenance History: $\quad$ Maintenance is a daily routine check of equipment that takes about 20 minutes. Although the biogas is scrubbed with an iron sponge prior to engine fueling, engine oil is changed every 300 hours.

Lessons Learned:

Tears in the digester's cover skirts dilute the energy content of the biogas by allowing air to enter. Despite this problem, the covered 
lagoon has, to date, worked well and has required little maintenance. An "off-the-shelf" modular engine/generator design should be fully developed. This could make start-up less costly and more flexible. Given current herd size and energy offsets, capital costs need to be reduced by $25 \%$ or more to enhance economic performance. The main areas where savings could be achieved are the lagoon cover and the lagoon heat exchanger. Cover costs could be reduced by design modifications or materials cost. "It may prove more cost-effective not to have a lagoon heat exchanger...However, a system could be designed to utilize the waste heat from the engine to supply the farm's heat energy needs ${ }^{1}$."

COSTING INFORMATION

Siting Cost:

Capital Cost:

Annual O\&M Cost:

End-Use of Biogas:

Prime Mover Type:
Included in capital cost.

$\$ 85,128$, but includes additional costs due to nature of project.

Not available, but estimated to be $\$ 2,500$.

Electricity with thermal reclaim used for digester heating.

25-kW model H225 Chrysler marine engine with a Kato generator.
ANNUAL SAVINGS

Electricity Production:

Electricity Offsets:

Thermal Production:

Thermal Offsets:

End-Uses of Effluent:

Other System Savings:

DESIGNER:

DIGESTER INSTALLER:

BALANCE OF SYSTEM:

OTHER CONTACTS:

Company:

Address:

Telephone:
Estimated at 150-175 thousand $\mathrm{kWh}$.

Estimated at $\$ 10,625$. $\$ 0.065$ is the current $\mathrm{kWh}$ charge.

Not applicable.

Not applicable.

Digester effluent goes to the second-cell storage lagoon and is later recycled to flush the swine houses on a continuous cycle. Excess liquids from the second cell are land-applied.

Reducing farm's average electric bill from $\$ 1,300$ to $\$ 400$ per month.

AgriWaste Technology, Inc.

Carroll's Foods of Virginia, Inc.

Resource Conservation Management, Inc.

Susan Thomas

Virginia Department of Mines, Minerals, and Energy

2201 West Broad Street

Richmond, VA 23220

8043670979

1. Gettier and Roberts (1994) Animal Lagoon Biogas Utilization System. Final project report to the Southeastern Regional Biomass Energy Program. 23 pages. 


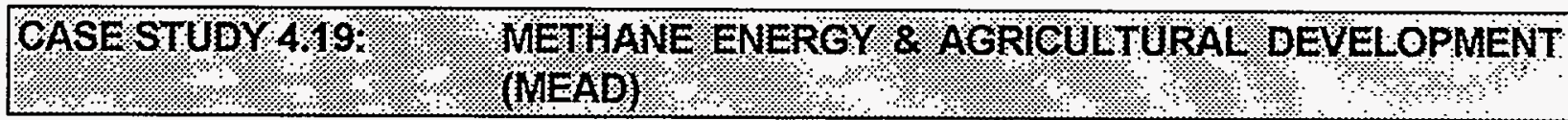

\begin{tabular}{ll}
\hline CONTACTS: & Gregory A. Booth \\
\hline Address: & Tillamook People's Utility District \\
& Post Office Box 433 \\
& Tillamook, OR 97141
\end{tabular}

Telephone:

5038424161

\section{GENERAL SYSTEM INFORMATION}

Herd Type:

Herd Size:

System Type:

Dimensions:

Capacity:

Gas Production:

Operational Date:

Estimated Life:

Current Status:

Project History:

Maintenance History:

Lessons Learned:
Dairy.

Up to 10,000 head from 40 or more area farms ${ }^{1}$.

Central.

To be determined.

121,000 gallons (467 tons) per day to 145,000 gallons ( 560 tons) per day with a 13 percent solids content.

441 million cubic feet per day (60\% methane content).

As early as 1995.

22 years.

Second engineering phase, seeking financing.

The project objectives are to: (1) convert cow manure into high-quality organic fertilizers and soil amendments and into biogas for electricity generation; and, (2) to return the treated liquid effluent to the participating farms for irrigating crops. It is envisioned that the project will operate with three distinct components. First, an anaerobic treatment facility will handle the manure and supplemental materials (fish or wood wastes) to produce biogas and a digested feedstock for a fertilizer plant. Second, a fertilizer plant will manufacture organic products from the digested materials produced at the treatment facility. Third, an energy facility will convert the biogas into electricity. In cooperation with the Port of Tillamook Bay, the Tillamook People's Utility District (TPUD) and Tillamook County Soil and Water Conservation District (SWCD) have entered into an agreement to jointly develop the MEAD project. These Agencies will provide a 20 acre site for the project, contract with area farms to provide manure supply, purchase biogas products, and provide assistance in permitting, financing and site improvements.

Not applicable.

Not applicable. 
COSTING INFORMATION

Siting Cost:

Capital Cost:

Annual O\&M Cost:

End-Use of Biogas:
$\$ 150,000$ spent on planning through June $1993^{2}$.

Between $\$ 14$ million for a 121,000 gallon per day facility to nearly $\$ 16$ million for a 145,000 gallon per day facility.

$\$ 3.0$ to $\$ 3.5$ million in Year 3 of project.

Electricity production with thermal reclaim used for digester heating. Winter manure volumes will produce enough biogas to generate approximately $920-\mathrm{kW}$. Seasonal variations in manure availability will reduce this production by 44 percent during the summer months to about 515-kW.

Prime Mover Type: $\quad$ To be determined.
ANNUAL SAVINGS

Electricity Production:

Electricity Offsets:

Thermal Production:

Thermal Offsets:

End-Uses of Effluent:

Other System Savings:

\section{OTHER CONTACTS:}

Company:

Address:

Telephone:
4.8 to 5.8 million $\mathrm{kWh}$ of net electrical production.

$\$ 288,000$ to $\$ 348,000$ at $\$ 0.06$ per $\mathrm{kWh}$. The preconstruction study estimated revenues from electrical sales at $\$ 290,866$.

Not applicable.

Not applicable.

Annually, the facility will produce 13,700 to 16,400 tons of blended fertilizer, 11,350 to 13,600 tons of soil amendments, 330 to 400 tons of grit, and 29.4 to 53.4 million gallons of liquid nutrients. Solid products will be sold. Liquid effluents will be returned to participating dairies for land application on pasturelands.

The preconstruction study found that the project will relieve the pressure to land-apply manure during winter months, a period of high manure collection and rainfall. Manure will be picked up from the farms and transported to the processing facility. It is projected that the liquid nutrient remaining from the digestion process will contain 75 percent less nitrogen than fresh raw manure now applied to pastureland. This will effectively eliminate the harmful bacteria normally present in untreated manure and prevent problems that may interfere with continued dairy farming.

\section{Alex Sifford}

Oregon Department of Energy

625 Marion Street, NE

Salem, OR 97310

5033782778

1. UNISYN. (1992) Tillamook Anaerobic Digestion Facility Preconstruction Study. Prepared with funding from the Oregon Department of Energy and the Pacific Northwest \& Alaska Bioenergy Program.

2. Tillamook County might plug into real cow power. The Oregonian June 2, 1993. 


\subsection{SUMMARY OF CASE STUDIES}

It must be remembered that the anaerobic digestion process is biologically-based, and therefore must be evaluated and implemented on a site-specific basis. As a result, few meaningful generalizations can be made. Factors required for successful project implementation include: an adequate match of digester type to the farm's manure management program, competent design and installation which simplifies digester operation and maintenance, maximization of co-product utilization to enhance economic performance, and, overall, an accommodating farm management and its willingness to incorporate the uncertainties of a new technology.

The list of reasons explaining why some anaerobic digestion projects fail must be headed by bad design or installation. When selecting the "best" qualified contractor to design or install an anaerobic digester system, an investor should rarely consider a firm without a significant amount of practical experience in the field. Poor equipment and materials selection is the second most common reason why digesters fail. Although buying the best and most expensive equipment and materials available cannot guarantee project success, amortizing the cost of quality components over the life-cycle of the project is a far better prospect than experiencing a failure resulting from the use of inferior products. The third reason is related to farm management. Even the best designed and installed digester made of quality components will fail in the hands of the "wrong" farm.

Excluding institutional factors (e.g., the farm was sold or closed, owner health, etc.) some of the primary causes of farm-based digester failure include ${ }^{1,2}$ :

1 Ashworth, J. (1985) Universe of US Commercial-Scale Anaerobic Digesters: Results of SERI/ARD Data Collection. Prepared by Associates in Rural Development for the Solar Energy Research Institute.

2 ICF Consulting Associates (1992) US Anaerobic Farm Digester Study.
"Shut down due to an inability to heat digester to desired level."

"Design problems; insufficient insulation and agitation; grit deposition; engine hydrogen sulfide corrosion."

"Insufficient gas production due to build-up of straw and foam."

"Eccentric design used unproven materials and concepts."

"Screening and sedimentation process inadequate; too many pumps; needs new generator and separator screen; hay from cow dirt clogs pumps; wind damage to digester cover."

"Engine overheating; $20 \%$ down-time in first 2.5 years; engine rebuilt; valve and pump problems; excess foaming and overflowing; manure freeze-up; power generation under design figures."

"Shut down because of maintenance problems; repairs regarded as too expensive."

"Severe gas leak; concrete cover cracked; four 90-degree pipe elbows caused plugged lines; sawdust and manure formed scum layer."

"Never produced enough gas to generate electricity; manure not rich enough for gas production to reach desired level."

"Plugging problems; digester operated periodically for one year."

"Cost overruns; commercial belt press does not dry solids adequately for bedding."

"Shut down because of engine malfunction."

"Start-up problems; debris plugged bedding equipment; soap in digester."

Unpublished report prepared for the US Environmental Protection Agency. 
"Start-up problems; debris plugged bedding equipment; soap in digester."

"Shut down due to poor maintenance; level of hydrogen sulfide requires additional scrubber; digester too small to service number of cows on farm."

"Digester design impractical for northern climates; sulfide scrubbing/removal problem; large fluctuation in digester efficiency due to different management over operational life."

"Shut down because of lack of use for gas; owner did not want to just vent gas."

"Breach of contract dispute between designer and installer."

"Digester never became operational at optimal level because of problems in creating desired $\mathrm{pH}$ balance."

"Floor that supported digester exploded; project abandoned."

"Shut down after two months because of straw build-up; chopper pump installed too late; builder went out of business shortly after digester installed and owner left with inoperative digester."

"Hydrogen sulfide corrosion in engine; plugging problems; owner cannot spend required time to repair and manage digester."

"Shut down because of a lack of funding and amount of time required for doing maintenance."

"System too small for farm; hydrogen sulfide corrosion."

"Shut down attributed to three factors: inability to filter hydrogen sulfide caused gas compressor failure; lack of community support, and; too much biogas consumed in heating digester and could not generate enough electricity. Project was a 'disaster'."

"Shut down because economically inefficient; might have been better if less biogas was used to heat digester; experienced problems in obtaining desired $\mathrm{pH}$ balance."
"Manure freeze-up; computer-controlled pressure and flame flare outlets did not function properly; insufficient gas production for feedstock volume."

"Poor design and pump problems in manure handling system; management problems forced shut down"

"Sand build-up in tank forced several cleanings; odor problem; escalating problems combined with falling commodity prices forced digester shut down." 
FIGURE 4.1: Status of Farm-Based Anaerobic Digesters in the US

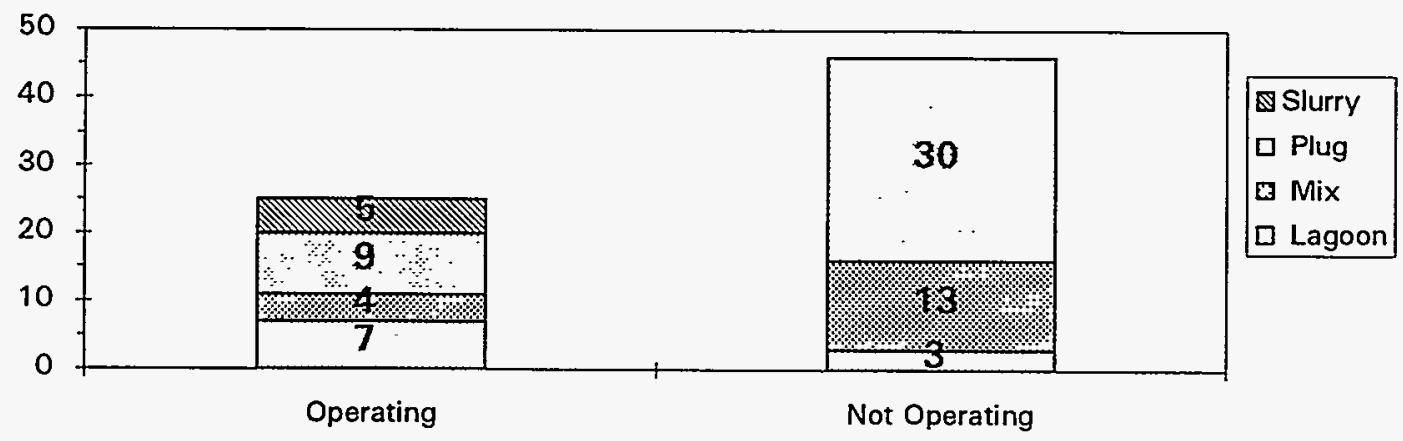

FIGURE 4.2: Performance of Farm-Based Anaerobic Digesters in the US

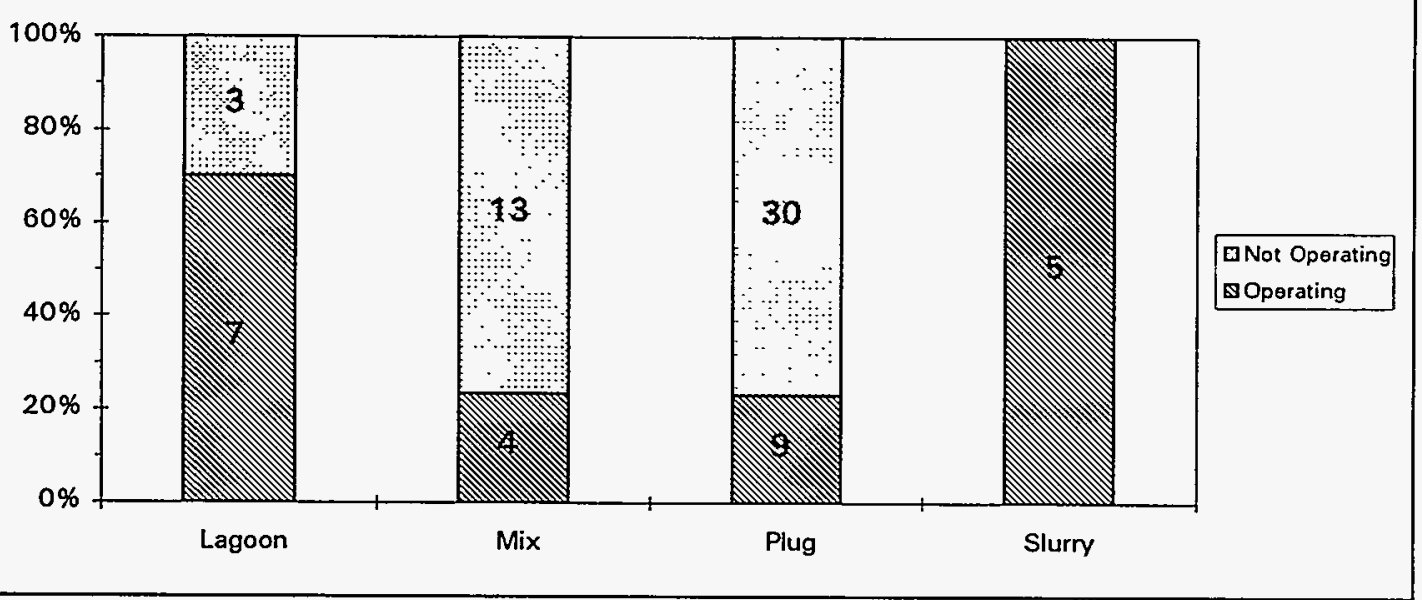




\subsection{SUMMARY CONCLUSIONS}

The conversion of agricultural wastes, animal manures in particular, into a renewable energy resource has been the focus of intensive research for well over two decades. Much has been learned about how manure can be utilized as an energy and nutrient source. Several available digester systems are both costeffective and easily managed; however, the American farmer has not been motivated to adopt these new practices. More cost-effective and easily-managed manure management techniques are still needed, especially for smaller farms, to encourage the farmer's use of animal waste for energy and nutrients.

Not only will farmers benefit monetarily, the use of anaerobic digestion also will help mitigate animal manure's contribution to air, surface, and ground water pollution. There are additional indirect benefits for sustainable rural economic development from the implicit multiplier effect resulting from the direct jobs that can be created by providing, installing and maintaining the digester system equipment. The implicit multiplier effect of integrated agricultural production and processing can be two to three times traditional production-only values.

Promising future waste-to-profit activities may enhance the economic performance of the overall farm manure management system. New end-use applications that can provide added value to co-products and maximize nutrient utilization include fuel cells for the generation of electricity and process heat, greenhouses, and algae, plant and fish aquaculture.

Fuel cells appear to offer a particularly clean and effective method of converting biogas into electricity and process heat. Instead of the 2025 percent electrical conversion efficiency from today's engine/generator technologies, fuel cells could produce electricity from biogas at a 40-50 percent conversion efficiency, a two-fold increase in productivity. When combined with process heat recovery, overall fuel cell efficiency is greater than 80 percent. Because of their high efficiency, fuel cells emit less carbon dioxide per kilowatt hour of electricity than current conversion technologies. The process also produces a minimal amount of carbon monoxide and nitrogen oxides, an issue of extreme importance to areas with substandard classifications under the Clean Air Act Amendments of 1990. With no moving parts, fuel cells also operate very quietly. Around sixty units that operate on natural gas have been sold world-wide. Two fuel cell projects using biogas are currently underway. One will demonstrate the recovery of biogas from a landfill in California, and the other will recover biogas from a waste water treatment facility in Maryland. The Maryland project also will reclaim waste heat for use by the facility's anaerobic digester.

Following the digestion process, diluted waste water effluent can be used as a nutrient source for hydroponic plant culture in attached greenhouses. Additionally, the use of attached greenhouses can provide enhanced plant growth rates if the available carbon dioxide is captured.

Discharged waste water effluent can also be discharged into ponds and used as a growth culture for algae or aquatic plants. Algae are up to 50 percent protein and can be used for many purposes. Currently, algae is produced for animal feed and as a soil amendment. Other algae that can be grown include Spirulina, a super-nutrient containing beta-carotene, a lipidrich algae that can be converted into a liquid diesel fuel substitute, and various algae that can be used as natural colorants or dyes.

Some species of duckweed, an aquatic plant that contains $35-45$ percent protein and has properties similar to algae, have phenomenal growth rates when grown in waste effluents. Fresh duckweed has been used as fish food with good results in Bangladesh, and dried duckweed meal has provided an excellent substitute for soy and fish meals in poultry rations in Peru. ${ }^{1}$

A combination of these activities could be incorporated on farms with multi-function production systems. "Agri-Plex" would be a

1

Skillicorn, et al. (1993) Duckweed aquaculture: a new aquatic farming system for developing countries. The World Bank, Washington, DC. 
more accurate name for such an operation. A project in Texas $^{2}$ is combining an anaerobic digester and the use of effluents to support the growth of algae and fish. The manures will first be flushed into an advanced facultative pond to produce biogas. In this approach, the cover floats just below the water surface rather than upon it as current lagoon covering techniques do. After initial treatment, the effluent will flow to additional ponds supporting the growth of algae and duckweed. Some algae and duckweed will be harvested and processed into animal feeds. The remainder will be used for the culture of fish, including tilapia, that will be processed into fish meal or sold as bait fish. An additional product will be a strain of bacteria that converts hydrogen sulfides into elemental sulfur, thereby helping reduce the odors associated with manure decomposition. Another potential revenue stream under consideration the production of water lilies, Louisiana irises, and other ornamental aquatic plants. While this system is capital and labor intensive, it provides the greatest potential for economic return.

Extending the anaerobic digestion process to recover methane has considerable potential beyond the farm to other industries with a waste stream characterization similar to livestock manures. Example industries include processors of milk, meat, food, fiber, and pharmaceuticals, among others. Some of these industries already recover methane for energy.

As a portion of the methane emission reduction component of the Climate Change Action Plan ${ }^{3}$ announced in 1993, the US Environmental Protection Agency (USEPA) and the US Departments of Energy (USDOE) and Agriculture (USDA) will expand a voluntary

2 Parker and Felder. (1994) "Bioenergy Production: Integrating Livestock Treatment with Byproduct Development', Proceedings, Bioenergy '94 Conference, S.L. Sargent, ed., Western Regional Biomass Energy Program, Golden, CO, Vol. 1, pp. 211-218.

3

Clinton and Gore. (1993) Climate Change Action Plan. Executive Office of the President, Washington, DC. pollution prevention program with the livestock industry. By signing the Memorandum of Understanding (MOU) in the voluntary AgSTAR program, a livestock producer agrees to explore profitable methane reduction activities. Under the MOU, producers survey farm facilities to identify profitable opportunities to capture and use methane and will install systems only where it is profitable to do so.

AgSTAR will address two significant barriers that limit on-farm methane recovery: (1) lack of familiarity with and understanding of available technologies; and (2) lack of effective financing mechanisms to implement those technologies.

Ignoring caged-layer poultry, market penetration estimates indicate that between four and five thousand dairy and swine farms could economically justify the implementation of anaerobic digestion from energy production offsets alone. Assuming an average of 100$\mathrm{kW}$ per facility, this rate of market penetration could add 400 to $500-\mathrm{mW}$ of distributed power to the grid using conventional engine/generator technologies.

AgSTAR is designed to reduce the cost of methane recovery technologies by increasing demand and by minimizing upfront expenses during initial project assessment. A key element is educational outreach in the form of workshops, comprehensive workbooks, and "field-day" tours that will explain the anaerobic digestion approach to the agricultural community and others.

AgSTAR will also support practical demonstration projects on working farms to help increase market penetration rates by informing livestock producers about the merits of anaerobic digesters. USEPA and USDOE are scheduled to conduct additional research, development, and deployment activities. Their objective is to expand the universe of economically justifiable opportunities across the livestock production sector by developing more cost-effective technologies for a wider range of facility sizes. Areas of activity may include: digestion processes and systems, gas recovery, handling and utilization systems, and effluent utilization systems. 
Because AgSTAR spans three major livestock groups (dairy, swine, and poultry), and costeffective options exist for each of these commodity groups, the potential for sizable program participation is apparent. USEPA, USDOE, and USDA are scheduled to make an extensive effort to identify key groups, organizations, and other institutions that can promote the program to producers at the county, state, regional and national level.

USEPA, USDOE, and the USDA also are ready to make an extensive effort to identify federal, state, local, and private lending institutions to develop financing mechanisms to assist producers in implementing cost-effective technologies. 


\subsection{SYSTEM DESIGNER \& INSTALLER CONTACTS}

\author{
AgriWaste Technology, Inc. \\ Dr. L.M. Safley, Jr., P.E. \\ 3504 Sloan Court \\ Raleigh, NC 27606 \\ tel: $\quad 9198518528$ \\ fax: 9198516482

\section{Agway Farm Research Center \\ Dr. Stan Weeks \\ 6978 New York Route 80 \\ Tully, NY 13159 \\ tel: $\quad 3156835700$ \\ fax: $\quad 3156839276$}

A.O. Smith Harvestore Products, Inc.

Dr. Rich Vetter

345 Harvestore Drive

DeKalb, IL 60115

tel: $\quad 8157561551$

fax: $\quad 8157562999$

BioRecycling Technologies, Inc.

Jim Hamamoto

6101 Cherry Avenue

Fontana, CA 92336

tel: $\quad 9098992982$

fax: $\quad 9098999519$

Enviroenergy Systems, Inc.

Paul Serbu

12030 Sunrise Valley Drive

Reston, VA 22091

tel: $\quad 7033916025$

fax: 7034760414

Environmental Treatment Systems

Chuck Ross

430 10th Street, Suite N-107

Atlanta, GA

tel: $\quad 4048758591$

fax: $\quad 4048758391$

Mason Dixon Farms, Inc.

Richard Waybright

1800 Mason Dixon Road

Gettysburg, PA 17325

tel: $\quad 7173344056$
Perennial Energy Corporation

Ted Landers

Route 1 Box 645

West Plains, MO 65775

tel: $\quad 4172562002$

fax: $\quad 4172562801$

Resource Conservation Management, Inc.

Mark Moser

166 Capricorn Avenue

Oakland, CA 94611

tel: $\quad 5106584466$

fax: $\quad 5106582729$

Rogers \& Callcott Engineers, Inc.

Frank D. Callcott, P.E.

P.O. Box 5655

Greenville, SC 29606

tel: $\quad 8032321556$

fax: $\quad 8032339058$

Sharp Energy, Inc.

Roy Sharp

20174 Road 140

Tulare, CA 93274

tel: $\quad 2096882051$

fax: 2096882051

UNISYN, Inc.

600 University Street, Suite 800

Seattle, WA 98101

tel: $\quad 2065215569$

fax: 2063827857

Rick Mattocks: 2062705241

NOTE: This should not be considered an exhaustive list of available consultants qualified to design or install on-farm anaerobic digesters. There are certainly consultants not identified in this listing who may be able to provide this service. The exclusion of any such consultant is not an indication of lack of service quality. 


\subsection{OTHER CONTACTS}

\section{DEPARTMENT OF ENERGY}

N. Michael Voorhies

Regional Biomass Energy Program

Office of National Programs, EE-522

1000 Independence Avenue, SW

Washington, DC 20585

tel: $\quad 2025861480$

fax: $\quad 2025868134$

\section{REGIONAL BIOMASS ENERGY PROGRAMS}

\section{NORTHEAST}

Richard Handley CONEG Policy Research Center, Inc. 400 North Capitol Street, NW

Suite 382

Washington, DC 20001

tel: $\quad 2026248454$

fax: $\quad 2026248463$

States served: $C T, D E, M E, M D, M A, N H$, NJ, NY, PA, RI, and VT.

\section{SOUTHEAST}

Phillip C. Badger, P.E.

Tennessee Valley Authority

CEB 5C

Muscle Shoals, AL 35660

tel: $\quad 2053863086$

fax: $\quad 2053862963$

C. David Stephenson

Tennessee Valley Authority

CEB 5C

Muscle Shoals, AL 35660

tel: $\quad 2053863087$

fax: $\quad 2053862963$

States served: AL, AR, FL, GA, KY, LA, MS, MO, NC, SC, TN, VA, and WV.
GREAT LAKES

Frederick J. Kuzel

Council of Great Lakes Governors

35 East Wacker Drive, Suite 1850

Chicago, IL 60601

tel: $\quad 3124070177$

fax: $\quad 3124070038$

States served: IL, IN, IA, MI, MN, OH, and WI.

\section{WESTERN}

David Swanson

Western Area Power Administrátion

1627 Cole Boulevard, Box 3402

Golden, CO 80401

tel: $\quad 3032751706$

fax: $\quad 3032751707$

States served: $A Z, C A, C O, K S, N E, N V$, NM, ND, OK, SD, TX, UT, and WY.

PACIFIC NORTHWEST \& ALASKA

Jeffrey James

Seattle Support Office

US Department of Energy

800 Fifth Avenue, Suite 3950

Seattle, WA 98104

tel: $\quad 2065532079$

fax: $\quad 2062532000$

States served: AK, ID, OR, MT, and WA.

ENVIRONMENTAL PROTECTION

AGENCY

Kurt F. Roos

AgSTAR Program Director

Mail Stop 6206-J

401 M Street, SW

Washington, DC 50460

tel: $\quad 2022339041$

fax: $\quad 2022339569$ 
Brian Steinwand

AgSTAR Program Manager

Mail Stop 6206-J

401 M Street, SW

Washington, DC 50460

tel: $\quad 2022339769$

fax: $\quad 2022339569$

Christine S. Lehnertz

Agricultural Outreach Coordinator

Mail Stop 6206-J

401 M Street, SW

Washington, DC 50460

tel: $\quad 2022339058$

fax: $\quad 2022339569$

\section{DEPARTMENT OF AGRICULTURE}

Dr. Lee P. Herndon, P.E.

National Agricultural Engineer

Natural Resource Conservation Service

PO Box 2890

Washington, DC 20013-2890

tel: $\quad 2027205014$

fax: $\quad 2027200428$

Harvey I. Mack

Program Manager

Natural Resource Conservation Service

PO Box 2890

Washington, DC 20013-2890

tel: $\quad 2027201871$

fax: $\quad 2027200630$

David C. Moffitt, P.E.

Supervisory Environmental Engineer

Natural Resource Conservation Service

South National Technical Center

PO Box 6567

Fort Worth, TX 76115

tel: $\quad 8173345242(\times 3304)$

fax: $\quad 8173345584$
James D. Rickman

Environmental Engineer

Natural Resource Conservation Service

South National Technical Center

PO Box 6567

Fort Worth, TX 76115

tel: $\quad 8173345242$ (x3306)

fax: $\quad 8173345584$

William H. Boyd

Environmental Engineer

Natural Resource Conservation Service

Midwest National Technical Center

100 Centennial Mall, Room 152

Lincoln, NE 68508-3866

tel: $\quad 4024385318$

fax: $\quad 4024385381$

Donald Stettler

Environmental Engineer

Natural Resource Conservation Service

Western National Technical Center

101 SW Main Street, Suite 1700

Portland, OR 97204-3076

tel: $\quad 5034143076$

fax: $\quad 5034143101$

Dr. W. Lamar Harris

Engineering \& Energy Program Leader

Agricultural Research Service

Rm. 238, Bldg. 005, BARC-W

Beltsville, MD 20705-2350

tel: $\quad 3015046061$

fax: $\quad 3015045467$

\section{UNIVERSITIES}

Dr. Bailey F. Green

Applied Algae Research Group

Environmental Engineering \& Health

Sciences Laboratory

University of California, Berkeley

1371 S. 46th Street, Bldg. 112, \#3580

Richmond, CA 94804-4608

tel: $\quad 5102315682$

fax: $\quad 5102319500$ 
Dr. Andrew G. Hashimoto

Professor \& Head

Bioresource Engineering

Gilmore Hall 116

Oregon State University

Corvallis, OR 91331-3906

tel: $\quad 5037372041$

fax: $\quad 5037372082$

Rick Koelsch

Senior Extension Associate

Agricultural and Biological Engineering

312 Riley-Robb Hall

Cornell University

Ithaca, NY 14853-5701

tel: $\quad 6072552495$

fax: $\quad 6072554080$

Dr. Nick C. Parker

Unit Leader \& Professor

TX Cooperative Fish and Wildlife

Research Unit

Texas Tech University

Lubbock, TX 79409-2125

tel: $\quad 8067422851$

fax: $\quad 8067422280$

Dr. Ann C. Wilkie

Research Assistant Professor

Soil and Water Science Department

Institute of Food and Agricultural

Sciences

University of Florida

PO Box 110960

Gainesville, FL 32611-0960

tel: $\quad 9043928699$

fax: $\quad 9043927008$ 


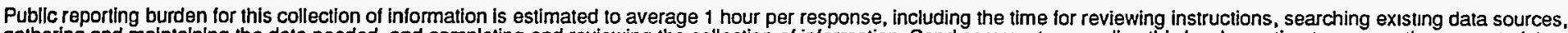

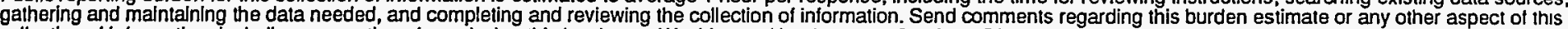

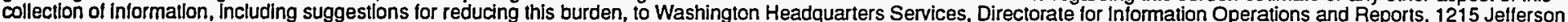

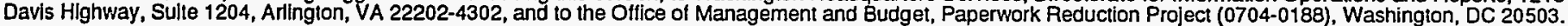

\section{AGENCY USE ONLY (Leave blank)}

\section{REPORT DATE}

December 1994

\section{TITLE AND SUBTITLE}

Methane Recovery from Animal Manures: A Current Opportunities Casebook

\section{REPORT TYPE AND DATES COVERED}

Subcontract Report

\section{FUNDING NUMBERS}

(C) CAE-3-13383-01

(TA) BF420433

\section{AUTHOR(S)}

P. Lusk

\section{PERFORMING ORGANIZATION NAME(S) AND ADDRESS(ES)}

Research Development Associates

240 Ninth Street, NE

Washington, DC 20002-6110

\section{PERFORMING ORGANIZATION REPORT NUMBER}

NA

10. SPONSORINGMONITORING AGENCY REPORT NUMBER

Natlonal Renewable Energy Laboratory

1617 Cole Boulevard

Golden, CO 80401-3393

NRELTP-421-7577

\section{SUPPLEMENTARY NOTES}

\section{2a. DISTRIBUTION/AVAILABILITY STATEMENT}

National Technical Information Service

U.S. Department of Commerce

5285 Port Royal Road

Springfield, VA 22161 12b. DISTRIBUTION CODE

UC-1403

\section{ABSTRACT (Maximum 200 words)}

This casebook examines some current opportunities for recovering methane from the anaerobic digestion of animal manures. U.S. livestock operations currently employ four types of anaerobic digester technology: slurry, plug flow, complete mix, and covered lagoon. An introduction to the engineering economies of these technologies is provided, and possible end-use applications for the methane gas generated by the digestion process are discussed. The economic evaluations are based on engineering studies of digesters that generate electricity from the recovered methane. Regression models, which can be used to estimate digester cost and internal rate of return are developed from the evaluations.

14. SUBJECT TERMS

anaerobic digestion, bioconversion, engineering economy, environmental quality, pollution prevention, sustainable development
18. SECURITY CLASSIFICATION OF THIS PAGE
19. SECURITY CLASSIFICATION OF ABSTRACT
15. NUMBER OF PAGES 90

16. PRICE CODE
17. SECURITY CLASSIFICATION OF REPORT
20. LIMITATION OF ABSTRACT

Standard Form 298 (Rev. 2-89) Prescribed by ANSI Std Z39-18 